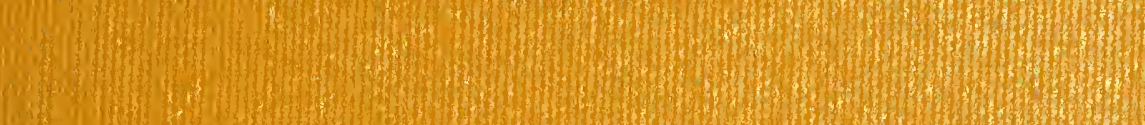
(1,

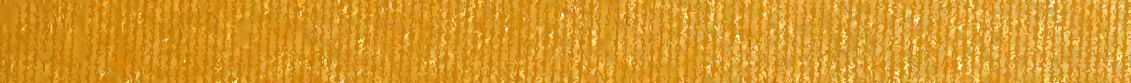
4. (4) W. 16. (4)

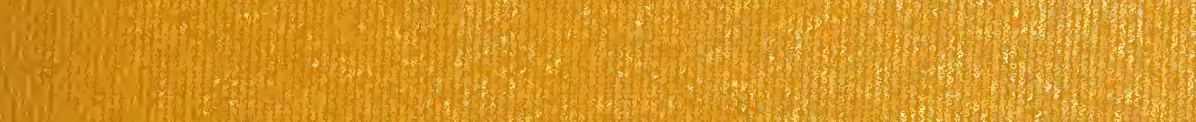
W.

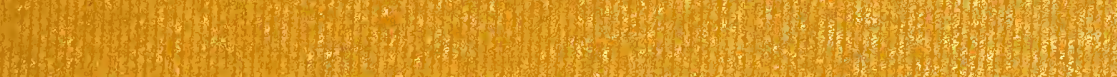

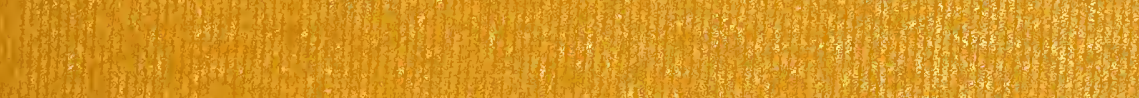
(19.5)

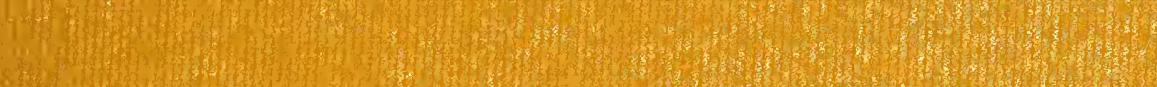
(6) 1. $n$
1

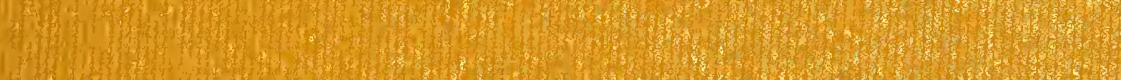

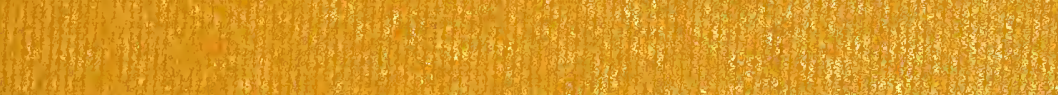

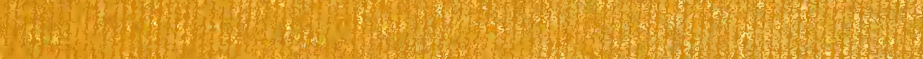
2. $502 x$

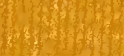

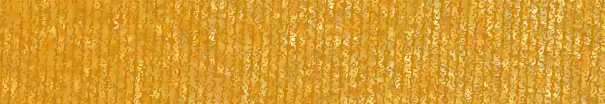

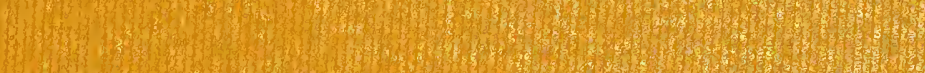
WX 


Digitized by the Internet Archive in 2011 with funding from

LYRASIS members and Sloan Foundation

http://www.archive.org/details/tobaccosubstatio1936ande 


\title{
TOBACCO SUBSTATION AT WINDSOR REPORT FOR 1935
}

\author{
P. J. Anderson, T. R. Swanback and O. E. Street
}

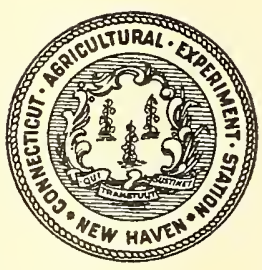

(Tomertiont

Agrimltural Fxprement Station

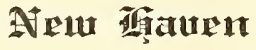


BOARD OF CONTPIOL.

His Excellency, Governor Wilbur L. Cross, ex-officio, President

Elijah Rogers, Vice-President. . . . . . . . . . . . . . . . . . . . Southington William L. Slate, Director and Treasurer . . . . . . . . . . . . . . . New Haven Edward C. Schneider, Secretary........................... Middletown

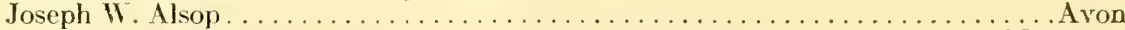
Charles G. Morris. . . . . . . . . . . . . . . . . . . . . . . . . . . . Newtown Albert B. Plant. . . . . . . . . . . . . . . . . . . . . . . . . . Branford

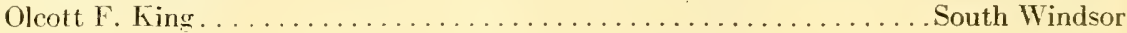

\section{STAFF}

Administration

Wirlay L. Slate, B.Sc., Director and Treasurer.

Miss L. M. Brautleght, Bookkeeper and Librarian.

Miss Katherine M. Palmer, B.Litt, Edilor.

G. E. Grafam, In Charge of Buildings and Grounds.

Analytical Chemistry.

Biochemistry.

Botany.

Entomology.

Forestry.

Plant Breeding.

Soils.

Tobacco Substation at Windsor.
E. M. Barley, Pн.D., Chemist in Charge.

C. E. Shepa RD

OWEN L. NolaN

Harry J. Fisher, Ph.D. \Assistant Chemists.

W. T. Mathis

DAVID C. WALDEN, B.S.

Miss Ianetha Shepard, General Assistant.

Chas. W. Soderberg, Laboratory Assistant.

V. L. Churchils, Sampling Agent.

Mrs. A. B. Vosmingh, Secretary.

H. B. Vickery, Рн.D., Biochemist in Charge.

George W. Pucher, PH.D., Assistant Biochemist.

G. P. Cunton, Sc.D., Botanist in Charge.

E. M. Stoddard, B.S., Pomologist.

Miss Florence A. McCornck, Ph.D., Pathologist

A. A. Dunlap, Ph.D., Assistant Mycologist.

A. D. McDonnels, General Assistant.

Mrs. W. W. Kelsey, Secrelary.

W. E. Bartron, Pн.D., D.Sc., Entomologist in Charge, State Entomalogist.

B. H. WALDEN, B.AgR.

$\left.\begin{array}{l}\text { M. P. Zappe, B.S. } \\ \text { Philip Garman, PH.D. }\end{array}\right\}$ Assistant Entomologists.

Roger B. FRIEND, PH.

Neley Turner, M.A.

JohN T. Ashworth, Deputy in Charge of Gypsy Moth Control.

R. C. Botsford, Depuly in Charge of Mosquito Elimination.

J. P. Jonnson, B.S., Depuly in Charge of Japonese Beelle Control.

Miss Helen A. Hulse

Miss Betty Scoville $\}$ Secretaries.

Walter O. Filley, Forester in Charge.

H. W. Hucock, M.F., Assistant Forester.

J. E. Ruley, JR., M.F., In Charge of Blister Rust Contral.

Miss Pauline A. Merchant, Secretary.

Donald F. Jones, Sc.D., Geneticist in Charge.

W. Ralph Singleton, Sc.D., Assistant Geneticist.

Lawrence C. Curtis, B.S., Assistant.

M. F. Mongan, Pr.D., Agronomist in Charge.

H. G. M. J A CoBson, M.S., Assistant Agronomist.

Herbert A. Lunt, Ph.D., Assistant in Forest Soils.

Dwight B. Downs, General Assistant.

Miss Gerildine Everett, Secrelary.

Paul J. Anderson, PH.D., Pathologist in Charge.

T. R. Swanback, M.S., Agronomisl.

O. E. Street, Ph.D., Plant Physiologist

C. F. Swansoy, Laboratory Technician.

Mise Dorotay Lenard, Secretary. 


\section{CONTENTS}

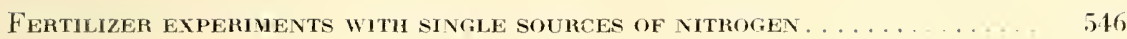

Vitrate Nitrogen ANd SOIL ACIDITY PRODUCTION BY Vitrogenous FErTILIZERS 5.92

Measurements of the Production of Nitrate Nitrogen . . . . . . . . . . . . 5.3.

Seasonal Characteristics of the Period . . . . . . . . . . . . . . . . 554

Residual Nitrogen and Early Availability. . . . . . . . . . . . . . . 554

Maximum Levels. . . . . . . . . . . . . . . . . . . . . . . . . 565

Relative Availability in Relation to Crop Needs . . . . . . . . . . 567

New Materials . . . . . . . . . . . . . . . . . . . . . . . . . . . . . 568

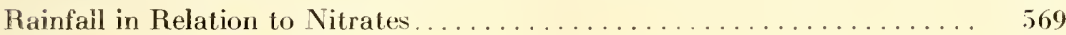

Speed of Recovery After Rains. . . . . . . . . . . . . . . . . 572

Soil Reaction as Influenced by Nitrogenous Fertilizers . . . . . . . . . . . . . . 573

Seasonal Fluctuation in Relation to Nitrates and Rainfall. . . . . . . . 573

Fluctuations Caused by the Fertilizer Material . . . . . . . . . . . . . 574

Conclusions . . . . . . . . . . . . . . . . . . . . . . . . . . . . . . 574

FURTHER FERTILIZER EXPERIMENTS WITH COTTONHULL ASHES . . . . . . . 574

Further INIESTIGATIONS ON THE USE OF FERTILIZER HAGNESIA . . . . . . . 578

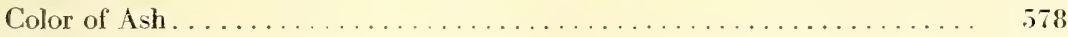

Annual Applications of Magnesian Lime. . . . . . . . . . . . . . . 580

Magnesia Application Based on Microchemical Soil Tests ............ $\quad 581$

Anhydrous Magnesium Sulfate as a Source of Magnesia . . . . . . . . . . . . $\quad 583$

EXPeriments to determine the Best tIME TO HARVEST HAVANA SEED TOBACCO $58 . \bar{\jmath}$

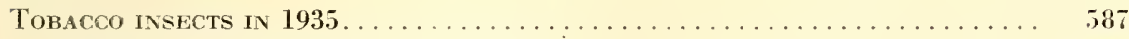

Prevalence of Insect Species in $1935 \ldots \ldots \ldots \ldots \ldots \ldots \ldots \ldots \ldots \ldots \ldots \ldots$

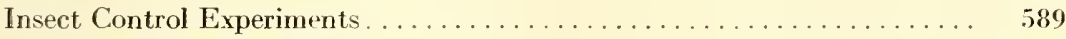

Tobacco Budworm . . . . . . . . . . . . . . . . . . . . . . . . . . 589

Potato Flea Beetle. . . . . . . . . . . . . . . . . . . . . . . . . . . . . 590

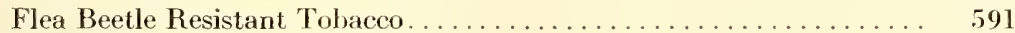

Tobacco Thrips. . . . . . . . . . . . . . . . . . . . . . . . . . . 591

Wireworm Investigations. . . . . . . . . . . . . . . . . . 592

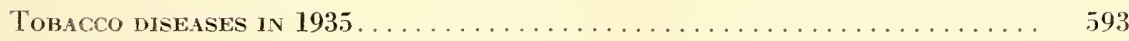

Dead-blossom Leaf Spot. . . . . . . . . . . . . . . . . . . . . . . . 595

Pythium Stalk-rot of Transplants. . . . . . . . . $59 \ldots \ldots \ldots \ldots \ldots$

Studies on Pole Rot. I. . . . . . . . . . . . . . . . . . . . . . 600

EfFEct of SHADE CLOTH on ATMOSPHERIC CONDITIONS............. 607 



\title{
TOBACCO SUBSTATION AT WINDSOR
}

\section{REPORT FOR 1935}

\author{
P. J. Anderson, T. R. Swanback and O. E. Street
}

\section{'THis, the fourteenth annual report of the Tobacco Substation,} describes the progress of experiments conducted at Windsor on fertilizers, cultural practices, diseases and insects of tobacco. It has never been our policy in these bulletins to review every line of work every year. Rather, we have taken up certain projects that have been under way for several years or that have yielded some reliable conclusions. The same system holds in the following pages.

The character of the weather during the growing and curing season has an important bearing on results for any one year. This is particularly true in the case of fertilizer experiments, although it applies somewhat to all field experiments. The point was well illustrated in the season of 1935 at Windsor. Besides wind storms that blew the tobacco over, there were heavy leaching rains at critical grow th periods when an abundant supply of nitrogen was most needed. Because most of our field experiments were nitrogen tests and the results would have been vitiated by the addition of mid-season nitrogen applications, no fertilizer was added after the rains. As a result, most of the tobacco, when cured, was found to contain a high percentage of starved, yellow, worthless leaves. Although this ruined the crop from a commercial standpoint, it was of immense value experimentally. It enabled us to compare the capacity of different fertilizer materials and of different quantities of fertilizer to loold up under such conditions.

In Table 1 , below, the rainfall by months and by 10-day periods is given. It will be noted that the June rainfall was about 2.5 inches above

Table 1. Distribution of Rainfall in Inches at the Tobacco Substation. WiNDSOR 1934-1935.

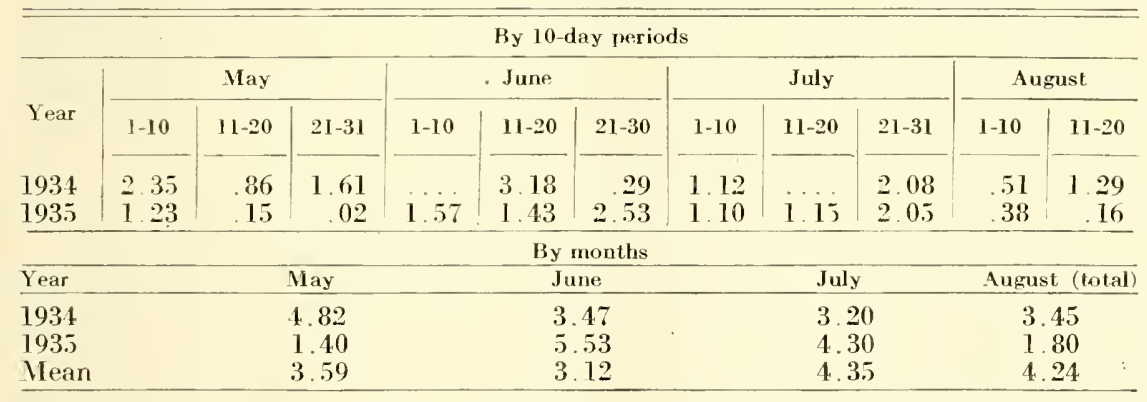

normal and that the excess was during the last few clays of the month (2.3 inches on June 29). This is near the beginning of the grand period 
of growth of tobacco plants, and chemical tests showed that the soil was practically depleted of available nitrogen, a deficiency that was not made up throughout the remainder of the growing season. Such a condition called for immediate application of additional nitrogen as a side dressing. The Station advised growers of the situation and many made such applications with beneficial results.

With the installation this year of instruments for measurement of maximum and minimum temperature and relative humidity, more complete weather records are now kept at this Station. A shelter of approved U. S. Weather Bureau type has been built to house these instruments and also a hygrothermograph, which gives a continuous record of temperature and relative humidity. The record of rainfall, which has been hept for several years, will be continued. Wind velocity, wind direction, and sunshine duration indicators, with their appropriate recorders, maybe added later.

The Station furnishes free service in testing soils as a guide to fertilizer practice and selection of fields for planting. Approximately 2,500 soil samples were submitted during 1935, indicating the increasing number of growers taking advantage of the service. Formerly the soils were tested only for acidity. Other tests were added as fast as their usefulness and reliability were fully demonstrated, until now the routine tests include potassium, calcium, magnesium, phosphorus, nitrate and ammonia nitrogen and, in special cases, aluminum, manganese and chlorine. These tests are also proving valuable in diagnosing malnutrition troubles in the growing crops.

During the year Mr. Lacroix. Station Entomologist, who has been studying the insects of tobacco for the last six years, has published a bulletin on "Insects of Growing Tobacco in Connecticut," which has been distributed as Connecticut Agricultural Experiment Station Bulletin 379 to all tohacco growers. It should be of considerable service in identifying and combating the ins ect enemies of tobacco.

\section{FERTILIZER EXPERIMENTS WITH SINGLE SOURCES OF NITROGEN}

A great many materials are available to furnish the necessary nitrogen in the tobacco fertilizer mixture and new ones appear on the market every year. It is a common belief among tobacco growers that certain ones have specific effects on the crop. For example, some hold that castor pomace makes the crop darker; linseed meal gives it a higher "finish": fish meal makes a red leaf, etc. For the most part, such ideas are based on personal observations or hearsay, or on claims of salesmen. and not on accurate experimental evidence. Also larger yields are claimed by the champions of each material.

The scientific agronomist, on the contrary, believes little in specific effects. He points out that these materials are first decomposed in the soil and absorbed by the plant as nitrates, or, to a less extent, as ammoniates. The nitrate is the same whether it originates from cottonseed meal, dry ground fish, nitrate of soda, or other sources. Why then, should the individual materials produce different results on the plants? One can only surmise that if such specific effects do occur, they must be due to different rates at which the materials decompose and hecome available. or to subsidiary elements that enter the roots with the nitrogen. 
As early as 1892, the Connecticut Agricultural Experiment Station began field experiments with the object of comparing the effects of different nitrogenous materials on the yield and grading of tobacco. Since that time there have been numerous similar experiments in this and other states witl various old and new nitrogenous materials, but still there is no agreement as to the comparative merits of even the common ones.

In 1926 this Station started a field experiment to compare four different nitrogenous materials with respect to their rate of nitrification, leaching and residual effect on the soil. From time to time since then, the project has been enlarged to include tests of additional materials and more replications. During these years the yields and gradings have been carefully determined and observations made to see whether any of the claimed specific effects could be detected and whether they were constant.

Progress on these experiments has been described in some of the previous publications, the latest of which was the report for 1931 (Conn. Sta. Bul. 335 : 239-246), to which the reader is referred for more complete details. Here we shall discuss only the results obtained since that time and present some conclusions. The old plots have been continued in the same location: a leachy, sandy loam on Field $\mathrm{V}$, and a new series on a more retentive, heavier soil on Field I. Havana Seed tobacco was used in these tests. In a third set of plots, the organic nitrogenous materials were compared on Broadleaf tobacco.

Table 2 gives a summary of the yields and grade indexes of the plots of the old series on Field $V$ for the last six years. Tab!e $2 \mathrm{~A}$ shows a similar summary for the new series on Field I, where the organic nitrogenons materials have been compared for four years. It will be noted that the yields are considerably higher on Field I than on Field $V^{\top}$. Table 4 summarizes four years results on the Broadleaf field.

Looking over the results of the three series of tests on three diflerent soils over a series of years, the following general conclusions seem warranted:

Cottonseed Meal. The fact that, in the old series, the yield for cottonseed meal was on the average less than that of the other organics is due probably to the unfavorable location of these two plots on more sandy soil than the others. In 1935, another cottonseed meal plot was added on more favorable soil on Field $V$ and it was noted that for this year the yield and grade index were in line with those for the other organics. Also in the four-year experiment on Field I, it will be seen from Table $2 \mathrm{~A}$ that the average yield was about the same as for linseed meal and only a little below that for the other organics. On the Broadleaf test, the yield was next to the highest. The grade index also compared very favorably. The common use of cottonseed meal as the standard base for tobacco mixtures seems to be vindicated by these tests.

Castor Pomace. In the six-year experiment on Field V, this material gave the highest yield of all, and in the four-year experiment on Field I, it was almost as high as any. The differences, however, are not large. Castor pomace has the reputation for producing a heavier yield of tobacco than cottonseed meal and the results of these experiments possibly furnish some support for such a claim. It is also a common belief that castor pomace produces darker tobacco. Such a difference in color has never 


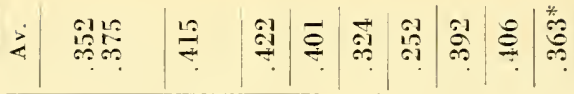

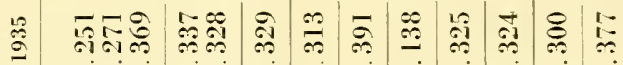

管

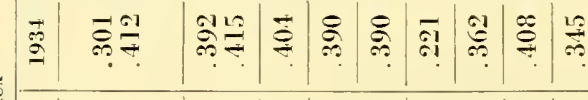

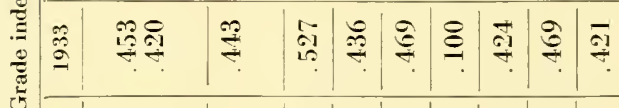

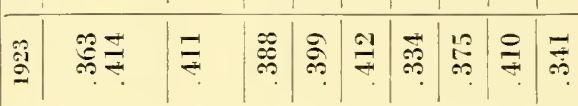

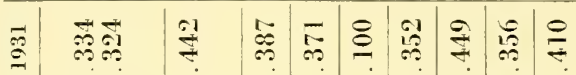

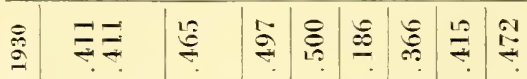

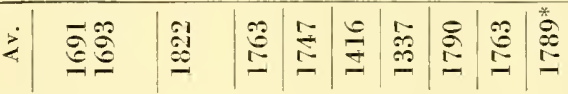

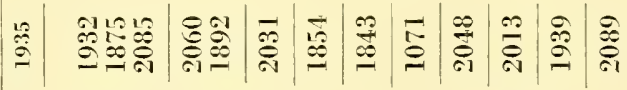

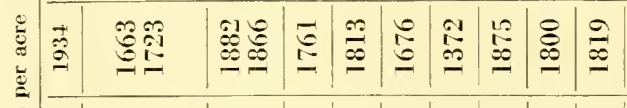

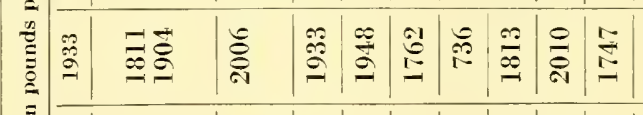

(2)

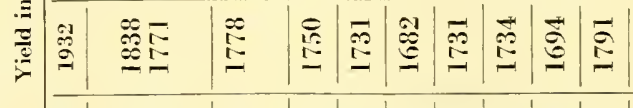

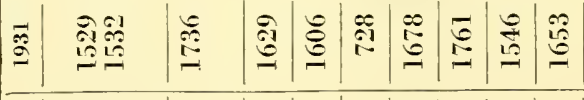

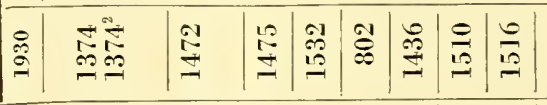


Table 2A. Single Sources of Nitrogen, New Series on Field 1.

Summary of Four Years' Results

\begin{tabular}{|c|c|c|c|c|c|c|c|c|c|c|c|}
\hline \multirow[t]{2}{*}{ Source of nitrogen } & \multicolumn{6}{|c|}{ Acre yield } & \multicolumn{5}{|c|}{ Grade index } \\
\hline & & 1932 & 1933 & 1934 & 1935 & Av. & 1932 & 1933 & 1934 & 1935 & Av. \\
\hline \multirow[t]{2}{*}{ Cottonseed meal } & (1) & 1928 & 1928 & 2090 & 2281 & \multirow{2}{*}{2086} & .353 & .466 & .470 & .366 & \multirow{2}{*}{.420} \\
\hline & (2) & 2053 & 1891 & 2171 & 2416 & & .411 & .457 & .475 & .364 & \\
\hline \multirow[t]{2}{*}{ Castor pomace } & (1) & 1776 & 1884 & 2111 & 2448 & \multirow{2}{*}{2130} & .383 & .453 & .424 & .363 & \multirow{2}{*}{.416} \\
\hline & (2) & 2014 & 185.5 & 2362 & 2591 & & .448 & .470 & .430 & .356 & \\
\hline \multirow[t]{2}{*}{ Linseed meal } & (1) & 2072 & 1918 & 2145 & 2265 & \multirow{2}{*}{2084} & .407 & .472 & .435 & .360 & \multirow{2}{*}{.431} \\
\hline & (2) & 1789 & 1880 & 2298 & 2308 & & .409 & .486 & .490 & .387 & \\
\hline \multirow{2}{*}{ Dry ground fish } & (1) & 2043 & 1941 & 2359 & 2380 & \multirow{2}{*}{2179} & .387 & .444 & .447 & & \multirow{2}{*}{.423} \\
\hline & (2) & 1966 & 1880 & 2390 & 2470 & & .389 & .447 & .484 & .363 & \\
\hline \multirow[t]{2}{*}{ Corn gluten meal } & (1) & 2005 & 1978 & 2307 & 2339 & \multirow{2}{*}{2134} & .391 & .444 & .456 & .338 & \multirow{2}{*}{.407} \\
\hline & (2) & 1745 & 1829 & 2400 & 2466 & & .363 & .459 & .468 & .333 & \\
\hline
\end{tabular}

been apparent during the six years of the Field $Y$ experiments, nor on the Broadleaf. During 1934, however, the tobacco from the castor pomace was judged to be darker on the heavier Field I plots, which in this case seems to support the belief of some growers that too much castor pomace should not be used on heavy soils. However, it seems to be a very good source of nitrogen for use on more sandy soils.

\section{Table 3. Lumed and Unlmed Sulfate of Ammonia Plots on Field I. Summary of Four Years}

\begin{tabular}{|c|c|c|c|c|c|c|c|c|c|c|}
\hline \multirow{2}{*}{ Fertilizer treatment } & \multicolumn{5}{|c|}{ Acre yield } & \multicolumn{5}{|c|}{ Grade index } \\
\hline & 1932 & 1933 & 1934. & 1935 & Av. & 1932 & 1933 & 1934 & 1935 & Av. \\
\hline Sulfate of ammonia & 1845 & 1912 & 2201 & 2017 & \multirow[b]{2}{*}{2013} & .379 & .435 & .442 & .347 & \multirow[b]{2}{*}{39} \\
\hline With lime & 1996 & 1994 & 2204 & 2016 & & 404 & .409 & .402 & 339 & \\
\hline Sulfate of ammonia & 1895 & 1896 & 1990 & 1691 & \multirow{2}{*}{1780} & .436 & .413 & .374 & .335 & \multirow{2}{*}{.35} \\
\hline Without lime & 1861 & 1659 & 1746 & 150.5 & & .457 & .380 & 261 & .200 & \\
\hline \multirow{3}{*}{$\begin{array}{l}\text { Neither sulfate of } \\
\text { ammonia nor lime }\end{array}$} & 2035 & 1940 & 1974 & \multirow{3}{*}{$\begin{array}{l}2133 \\
2045\end{array}$} & \multirow{3}{*}{2017} & .404 & .476 & .409 & .351 & \multirow{3}{*}{.42} \\
\hline & 2051 & 2050 & 1898 & & & .420 & .506 & .391 & .355 & \\
\hline & 2031 & 2036 & 2001 & & & .429 & .495 & .405 & & \\
\hline
\end{tabular}

Linseed Meal has given favorable results in all tests. The yield is no better than that from other sources, but it may be significant that the average grade index has been invariably higher for this than for any other material. This means that the tobacco from these plots has been judged each year to be of a little better quality than that from the other plots. At various times the leaves have been examined and compared 
with those from adjacent plots to see whether the claimed "better finish" could be observed. When the same grades were compared, this superiority was not so apparent. It is true, however, that the linseed plots yielded a somewhat higher percentage of leaves in the best grades and this accounts for the higher grade index.

Linseed meal appears thus to be an excellent source of nitrogen for tobacco. Unfortunately it is usually more expensive than some of the other organic materials.

Dry Ground Fish gave very high yields in all tests and was like castor pomace in that respect. The grade index has been about the same as for cottonseed meal.

Corn Gluten Meal has also given very high yields in all tests. The grade index, however, is on the average a little lower than that of the other organics.

Soy Bean Oil Meal (a by-product of the soy bean oil industry) contains approximately the same plant food elements and in the same proportions as cottonseed meal. It has come on the market in ever increasing quantities in recent years, due to increase in domestic production of soy beans, and promises to be a permanent competitor of the cottonseed product. Also during the last year the price has been lower. The soy bean oil meal was tried on one plot on Field $V$ adjacent to the others of the old series for the first time in 1935 . It produced very excellent tobacco with a higher grade index than for any of the other organics, and did not show the starved condition which was so evident on most of the plots this year. A one-year test on a single plot, however, does not furnish sufficient data from which to draw any sweeping conclusions.

Nitrate of Soda. This is the most available and most easily leached of all the materials tested. During the first six years of the experiment, all of the fertilizer was applied broadcast about ten days before the plants

Table 4. Single Sources of Nitrogen. Broadleaf Plots. Summary of Four Years.

\begin{tabular}{l|l|l|l|l|l|l|l|l|l|l|l|l}
\hline \hline $\begin{array}{l}\text { Plot } \\
\text { No. }\end{array}$ & Source of nitrogen & \multicolumn{5}{|c|}{ Acre yields } & \multicolumn{4}{c}{ Grade index } \\
\cline { 2 - 11 } & 1932 & 1933 & 1934 & 1935 & Av. & 1932 & 1933 & 1934 & 1935 & Av. \\
\hline N49 & Cottonseed meal & 1721 & 1872 & 2183 & 1813 & 1897 & .465 & .426 & .474 & .231 & .399 \\
N50 & Castor pomace & 1430 & 1938 & 2123 & 1866 & 1839 & .346 & .462 & .455 & .241 & .376 \\
N51 & Linseed meal & 1600 & 1946 & 2241 & 1771 & 1889 & .448 & 453 & .515 & .303 & .430 \\
N52 & Dry ground fish & 1460 & 1892 & 2206 & 1871 & 1857 & .396 & .474 & .467 & .219 & .389 \\
N53 & Corn gluten meal & 1562 & 1982 & 2358 & 1906 & 1952 & .390 & .462 & .437 & .248 & .384 \\
\hline \hline
\end{tabular}

were set (at the same time as the other fertilizers). Since the land was quite sandy on this plot, most of the nitrogen was leached out each year when there were heavy rains during the first part of the season. As a result, the starved crop was almost worthless when cured. During the last four years however, in order to overcome this, the nitrate was applied fractionally in five applications at intervals of about ten days. 
By this practice, very good tobacco has been grown on sandy land with nitrate of soda as the only source of nitrogen. The average yield on this plot for the first six years was $\mathbf{8 4 9}$ pounds. During the last four years (fractional application) it was 1,741 pounds, or more than double the average of the previous six years but not quite so good as the adjacent cottonseed meal plot at 1,811 pounds for these same four years. The average grade index for the first years was .185 (with cottonseed meal at .338) while for the last four years it was .415 (cottonseed .342). Particularly interesting is the grading record of the tobacco from this plot in 1935. Most of the tobacco on the other plots of this series (except the soy bean meal plot) was poor, yellow and starved, showing the results of leaching. But the nitrate of soda plot showed very little starvation and the grade index was highest of all on the plots of this series.

Thus it might be possible to grow good tobacco on a nitrate alone as the source of nitrogen, if one distributed the applications properly throughout the growing season. Such a program would involve additional labor and would not be very practical for the average grower. The humus content of the soil could be kept up by turning under winter cover crops. It is probable that the principal use for nitrate of soda (or other nitrates) in tobacco culture will continue to be as a side dressing, applied between the rows of the growing crop for quick replenishment of the nitrogen after leaching rains.

Sulfate of Ammonia. This material has been found to be the least desirable of all the nitrogenous substances tested. Results of all our experiments on sulfate of ammonia up to 1933 were published in full in our report for that year (Com. Sta. Bul. 359: 355-360) to which the reader is referred for a full discussion. Continuous use of sulfate of ammonia (without lime) makes the soil more acid each year until it finally reaches a point where tobacco will hardly grow. Long before that, however. the leaves become very poor in quality. Use of sulfate of ammonia makes them darker, heavier and more prominently veined. The fireholding capacity is reduced, the ash darker, and the taste and aroma inferior.

Since some of these defects are obviously related to the acidifying effect of sulfate of ammonia in the soil, the possibility was suggested that they might be overcome by adding sufficient lime to neutralize this tendency. Accordingly, four plots were started on Field I in 1932 with sulfate of ammonia as the only source of nitrogen. To two of these plots, 1,000 pounds of high calcic limestone to the acre was added the first year, 1,200 pounds of magnesian lime the second year, and 2,000 pounds of magnesian lime the third year. In the spring of 1935, the reaction of the soil on the limed plots was $\mathrm{pH} 5.55$, and on the unlimed plots was $\mathrm{pH} 4.25$. Therefore no more lime was added.

The results of four years' test, as seen in Table 3, show that the use of lime has kept the yield up to the level of other sources of nitrogen and that the decreased yields that have been observed in our other experiment may be prevented by liming. The grade index, however, has not been kept up and the tendency to produce dark, heavy tobacco has not been overcome.

Urea. As may be seen in Table 2, the yield on the urea plot has been 
maintained at a high level (second only to castor pomace) despite the fact that the soil is light and sandy. The use of urea alone, at the rate of 200 pounds of nitrogen to the acre, has had a tendency to produce somewhat darker, heavier tobacco, and as a result the average grade index is not so high as for some of the other materials. It is probably best not to use this material as the one source of nitrogen, but more extensive tests recorded in our previous reports show very good results where urea is used to furnish a percentage (up to 50 per cent) of the nitrogen of the formula.

Calnitro, a mixture of ammonium nitrate and calcium carbonate, has maintained both the yield and the grade index at a level almost as high as other sources. It is hardly suitable to use as the only source of nitrogen in the formula but might be substituted for a part of the more expensive materials.

Discussion of Results. Averaging all the results of the experiments through a series of years, one is impressed by two facts: So far as yield is concerned, there is little choice among the different organic materials: also among the grade indexes the differences are not impressive. Possibly the better showing for linseed meal and somewhat lower grading for corn gluten meal may be of sufficient magnitude to be significant. A grower may reduce his fertilizer bill by watching the market and choosing any of the other materials tested that happen to be cheaper in a given season. A certain percentage of urea and calnitro may also be used to advantage in such substitution. Sulfate of ammonia cannot be recommended. If used at all, only a small percentage of nitrate of soda (and other nitrates) should be included in the original mixture for broadcasting. but the grower should keep a supply on hand for side dressing to be applied immediately after leaching rains. Soy bean oil meal is a promising new organic but has not been sufficiently tested to warrant recommendation at present.

\section{NITRATE NITROGEN AND SOIL ACIDITY PRODUCTION BY NITROGENOUS FERTILIZERS}

\section{O. E. Street}

Since the inception of the industry, nitrogenous fertilizers have occupied the foremost position in the nutrition of Connecticut Valley tobacco. The classic example of the Indian placing a fish in a hill of corn was soon imitated by the early settlers and can reasonably be interpreted as the earliest example of nitrogen fertilization. The use of farm manures for tobacco growing was an early and wide-spread practice and still persists, though on a much reduced scale. More than 50 years ago, cottonseed meal was tried as a tobacco fertilizer and soon rose to the dominant position it still occupies. Other vegetable organics such as castor pomace and linseed meal; animal organies such as dry ground fish, Peruvian guano, hoof and horn meal, tankage and blood; and nitrate of soda among the inorganics, were added to the list and peculiar virtues attributed to each. Sulfate of ammonia, a by-product of the gas and coke industry, also found 
a limited use. Within the last 15 years, the development of nitrogen fixation processes to a position of economic production brought such materials as urea, nitrate of potash, nitrate of lime, ammonium nitrate, ammonium phosphate and cyanamid on the market and led to their trial in tobacco fertilization. By-products of the manufacture of food products recently added to the list include corn gluten meal and soy bean oil meal, while the tobacco industry itself supplies stems and stalks which contain from 1 to 1.5 per cent nitrogen as well as a higher potash content.

A comparison of some of these sources as the sole carrier of nitrogen has been in progress at this Station for 10 years and results have been reported in Tobacco Station Bulletin 10, Report of 1927; Conn. Exp. Sta. Bul. 299, Report of 1928; Conn. Exp. Sta. Bul. 335, Report of 1931. Originally planned as a study of leaching and soil reaction, the records now include yield and grading data for the entire period. Four plots on which cottonseed meal, nitrate of soda, urea and sulfate of ammonia were compared as single sources, comprised the entire experiment at first. Gradually others were added until, in 1935, 12 sources were being studied on 15 plots. The 4 materials first used have occupied their original plots during the entire 10 years. Castor pomace, linseed meal and dry ground fish have been undisturbed since 1929, cal-nitro since 1930, and corn gluten meal since 1932. Fertilization has been on an acre basis of 200 pounds of nitrogen since 1928, before which it was 164 pounds per acre.

\section{Measurements of the Production of Nitrate Nitrogen}

The large differences in yield, quality and soil reaction produced by the various classes of materials represented in the original experiment, as well as the smaller differences produced by the materials later added, led to the introduction in 1932 of measurements of the soil nitrate levels. The tobacco plant takes up most of its nitrogen from the soil in the form of nitrates. But, except for nitrate of soda and calnitro, the materials mentioned contain little if any nitrogen in the form of nitrates. The nitrogen in cottonseed meal and most of the other materials is called unavailable and camnot be used immediately by the plant. It is only by complicated decomposition processes carried on by soil organisms that it is broken down to nitrates and becomes available to the plant. The speed of the breaking-down process is different for each material. By measuring the quantity of nitrate nitrogen present in the soil at frequent intervals, it is possible to obtain a detailed picture of growing conditions throughout the season. Each measurement represents the difference between the amount of nitrates produced from fertilizer and soil organic matter and the amount taken out by the growing plant and by heavy rains. As nitrate is also the form in which the nitrogen is most easily washed out of the soil by heavy rains, these same tests give an indirect measure of the amount of leaching. The need of these measurements as an indication of the differences between these materials in rate of availability, resistance to leaching, and recovery from heavy rains was apparent. The most frequent question asked by the growers of Connecticut Valley tobacco in reference to nitrogen fertilizers deals with the speed at which these materials nitrify and the probable effect of their behavior on the growth and quality of the tobacco. 
Measurements of the soil nitrates and soil reaction were made from April through September, of the years 1932, 1933, 1934 and 1935, at weekly intervals during June, July and August, and at wider intervals in the spring and fall. These data for nitrate nitrogen are presented in Tables 5, 6, 7, and 8, and for soil reaction in Tables 9, 10, 11 and 12 . while the four-year averages are to be found in Tables 13 and 14. The average nitrate levels and soil reaction for all organic sources are graphically shown in Figure 129, while the corresponding results for the inorganic sources and the plot receiving no nitrogen are shown in Figure 130. The correlation between nitrate levels and rainfall distribution and amount for a year of low summer rainfall, 1932, and one of higher rainfall (as well as irrigation), 1934, is shown for typical materials in Figures 131 and 132.

Seasonal characteristics of the period. The classification of summer seasons as dry or wet in relation to nitrification, may not furnish an accurate criterion of growing conditions, as such factors as distribution of rainfall and average temperatures are not taken into account. Departures from the optimum in growing conditions may be due to low temperatures or poor distribution of rainfall as well as to excessively wet or dry conditions. Thus early availability may be low because of a cold, dry spring, under which conditions the decomposition of protein materials would be limited by both the shortage of water and unfavorable temperature. Again, the total rainfall for a month may equal the exact mean. but if it all fell in one or two periods of two inches each, the result might be serious damage to the crop rather than uniform growth. An abrupt change in weather conditions from cool and moist to dry and hot will often find the plants with poorly developed and shallow root systems and the crop will almost cease growth. Wilting will be common, and the value of the crop will be greatly impaired.

The four years during which the tests were made ranged from perhaps an average growing season in 1932 to an abnormally wet season in 1935, with 1933 rather dry throughout, and 1934 of adequate early rainfall but very dry during the greater part of the growing season. Cool and dry conditions were prevalent during the early part of the growing season of 1932, but a favorable rainfall distribution during most of the time the tobacco was in the field maintained nitrates at a rather high level. During 1933 the general level of nitrate production was low for the entire season because of inadequate rainfall. Irrigation failed to stimulate nitrification, in contrast to a natural rainfall in early July, which produced a moderate stimulation. The season of 1934 was one of moderate rainfall until June 20 , followed by five weeks of drought, broken only by an inch of rain during the third week. Nitrates were never at high levels. After abnormally dry conditions in April and May of 1935, June and July were months of high rainfall. Precipitation of more than two inches fell on June 29 and more than one inch on July 19, and nitrates were at a starvation level during a large part of the growing season.

Residual nitrogen and early availability. Nitrate determinations in April of three years show definitely that the quantity of nitrates left after the winter and spring rains is very low, and that nitrification, either of unused fertilizer of the previous year, or of the natural organic matter 


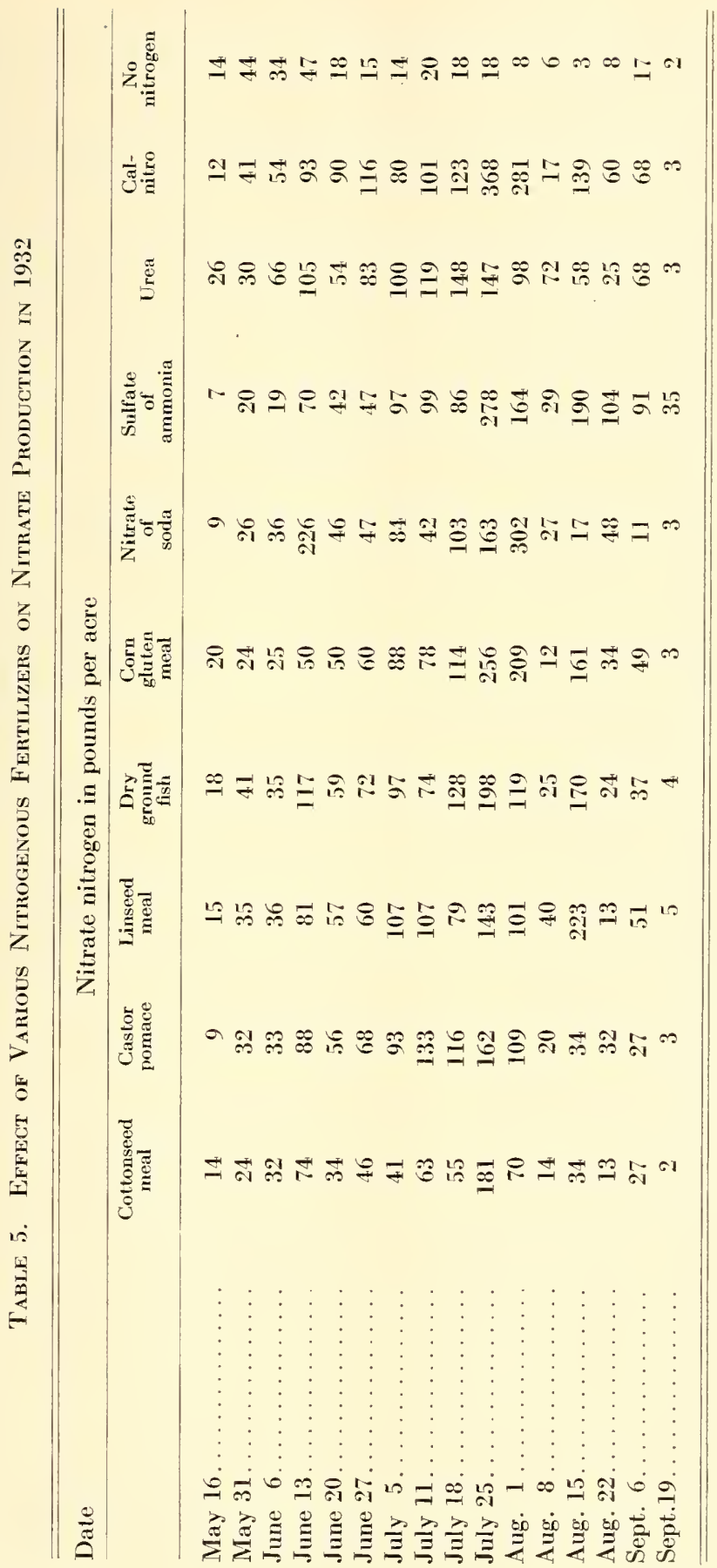




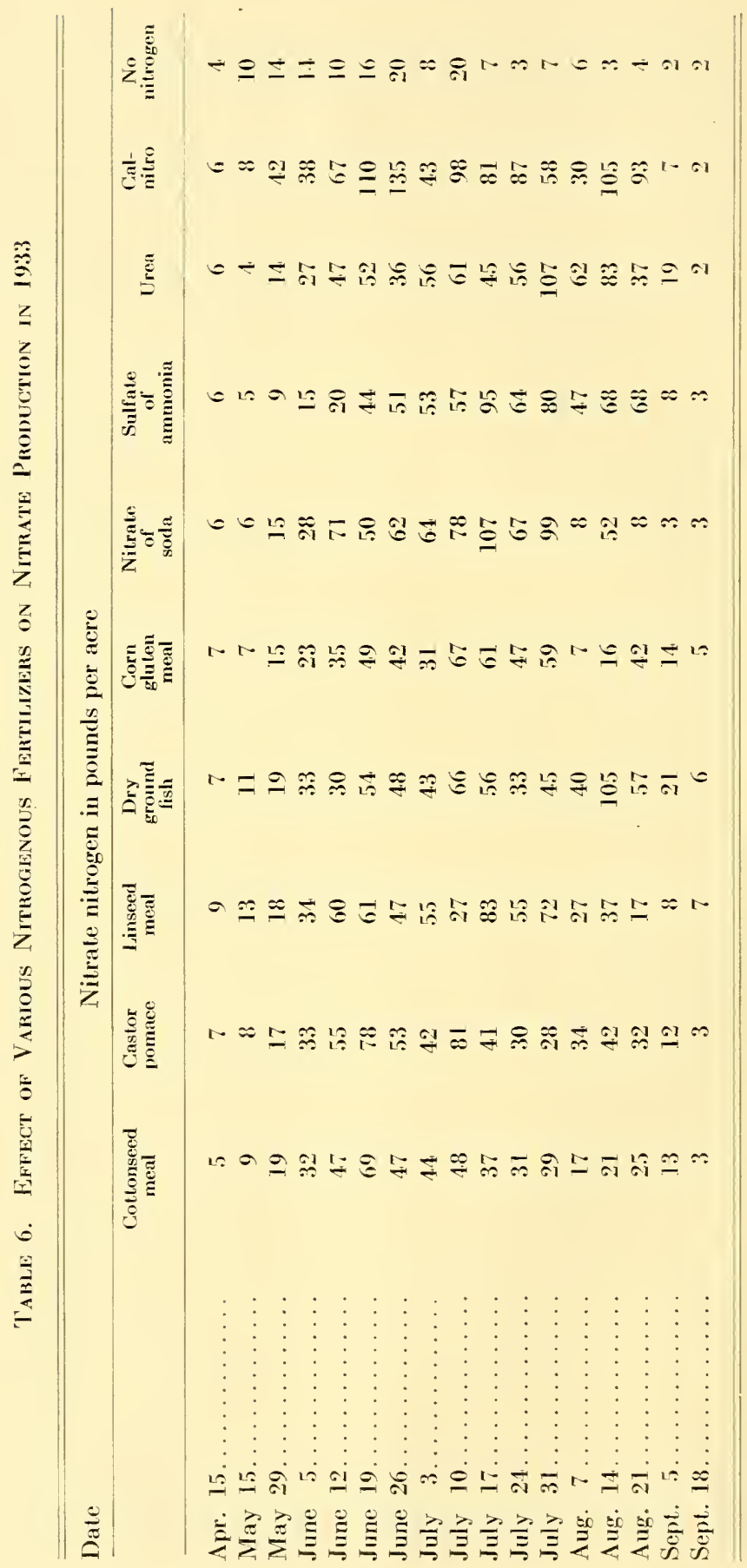


Effects of Nitrogenous Fertilizers

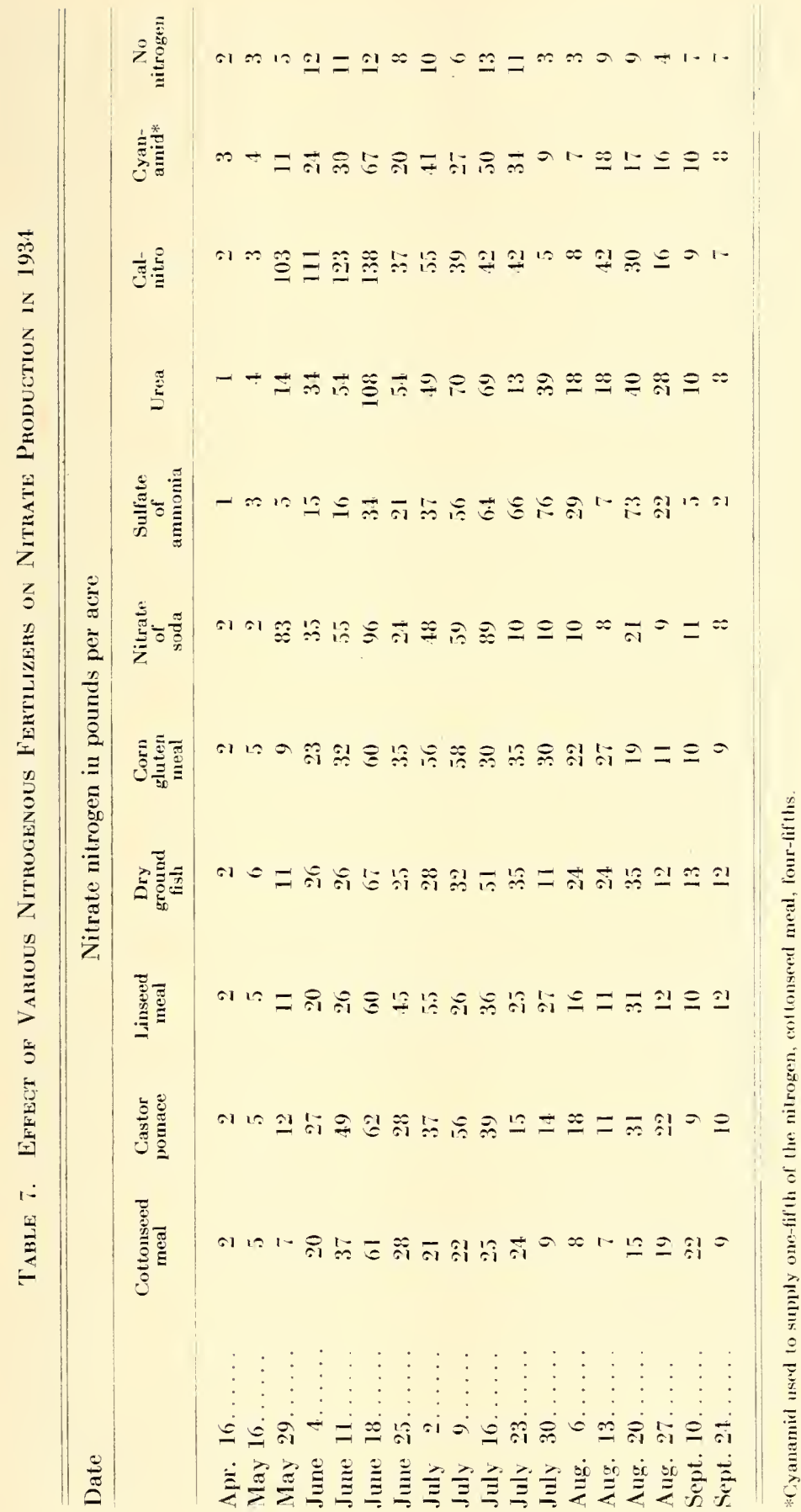




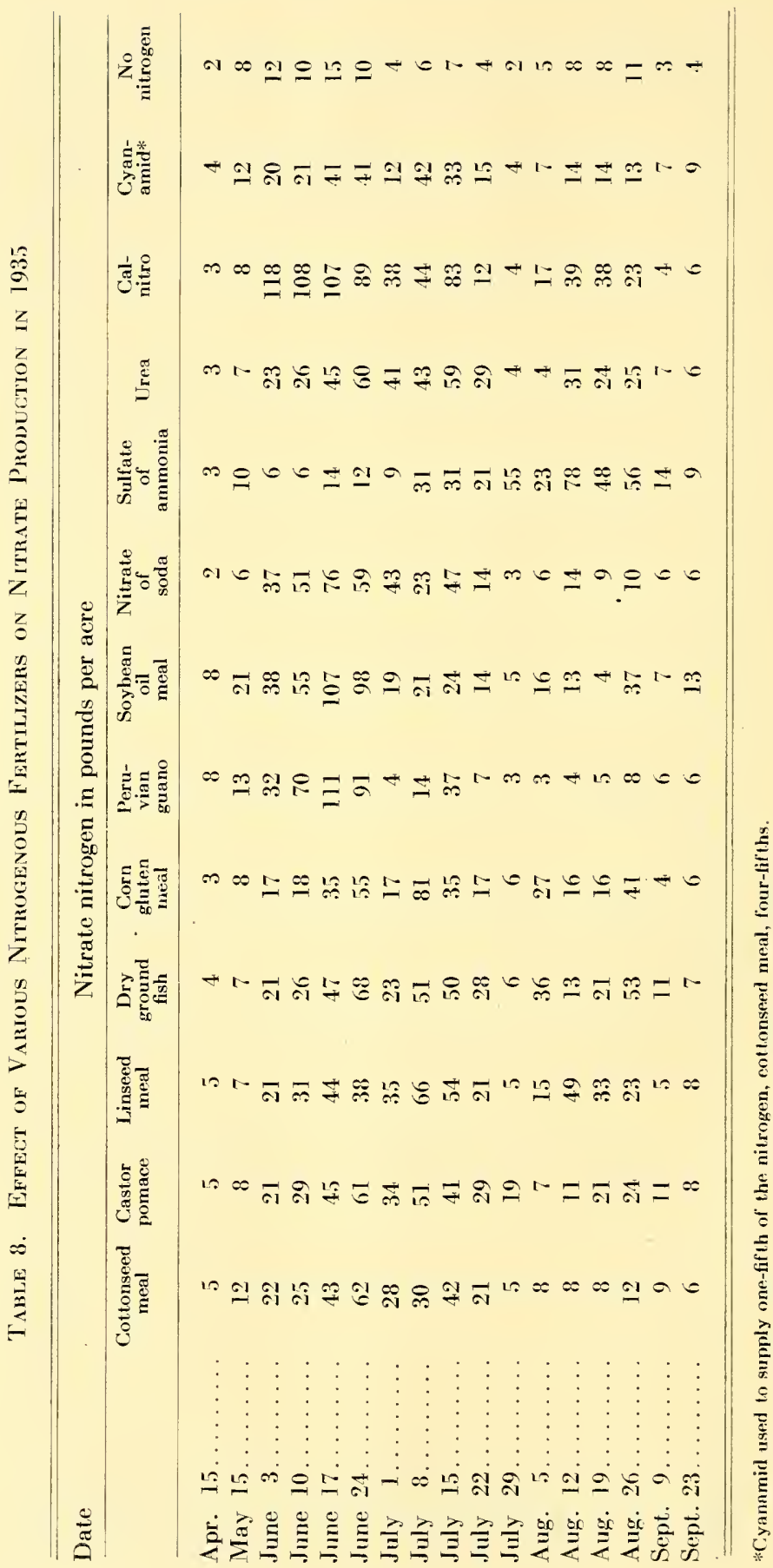




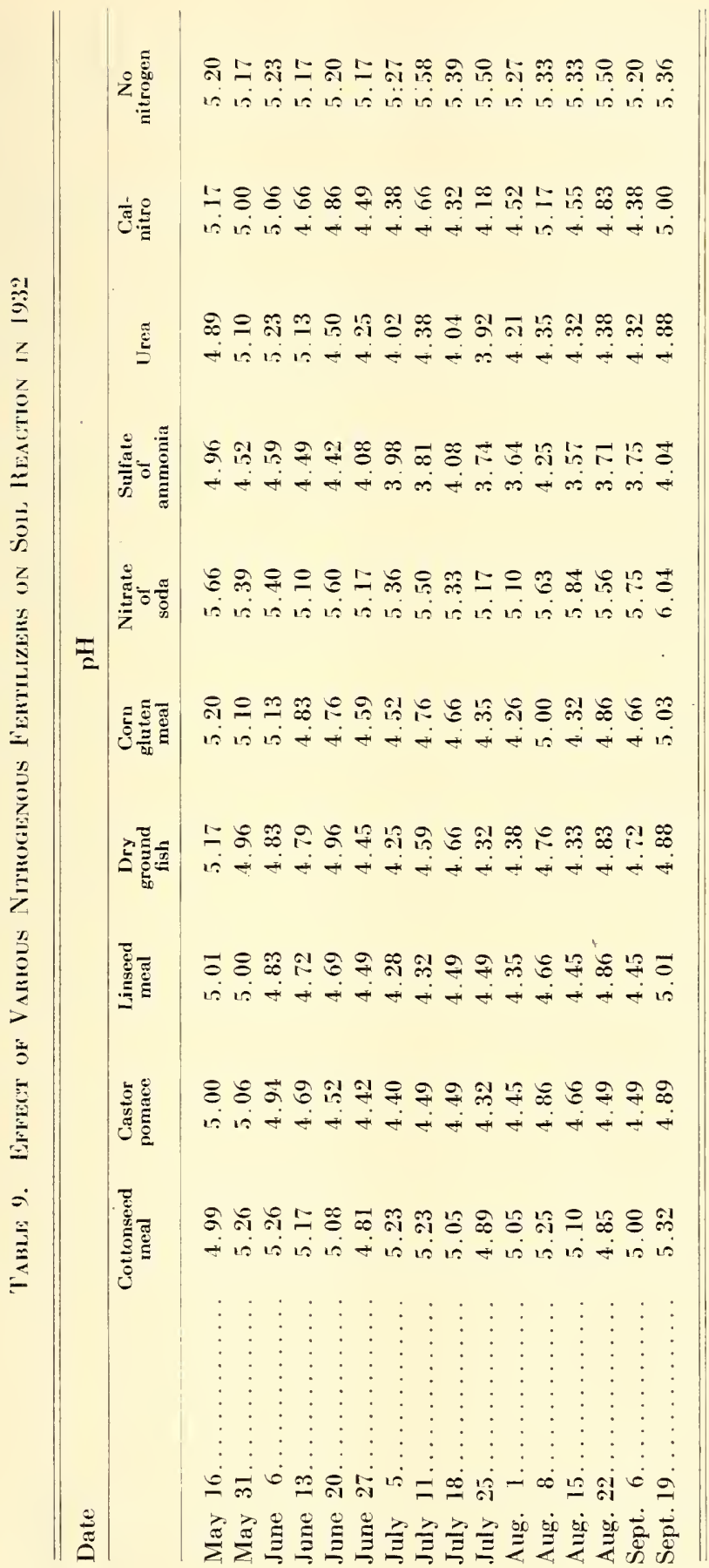




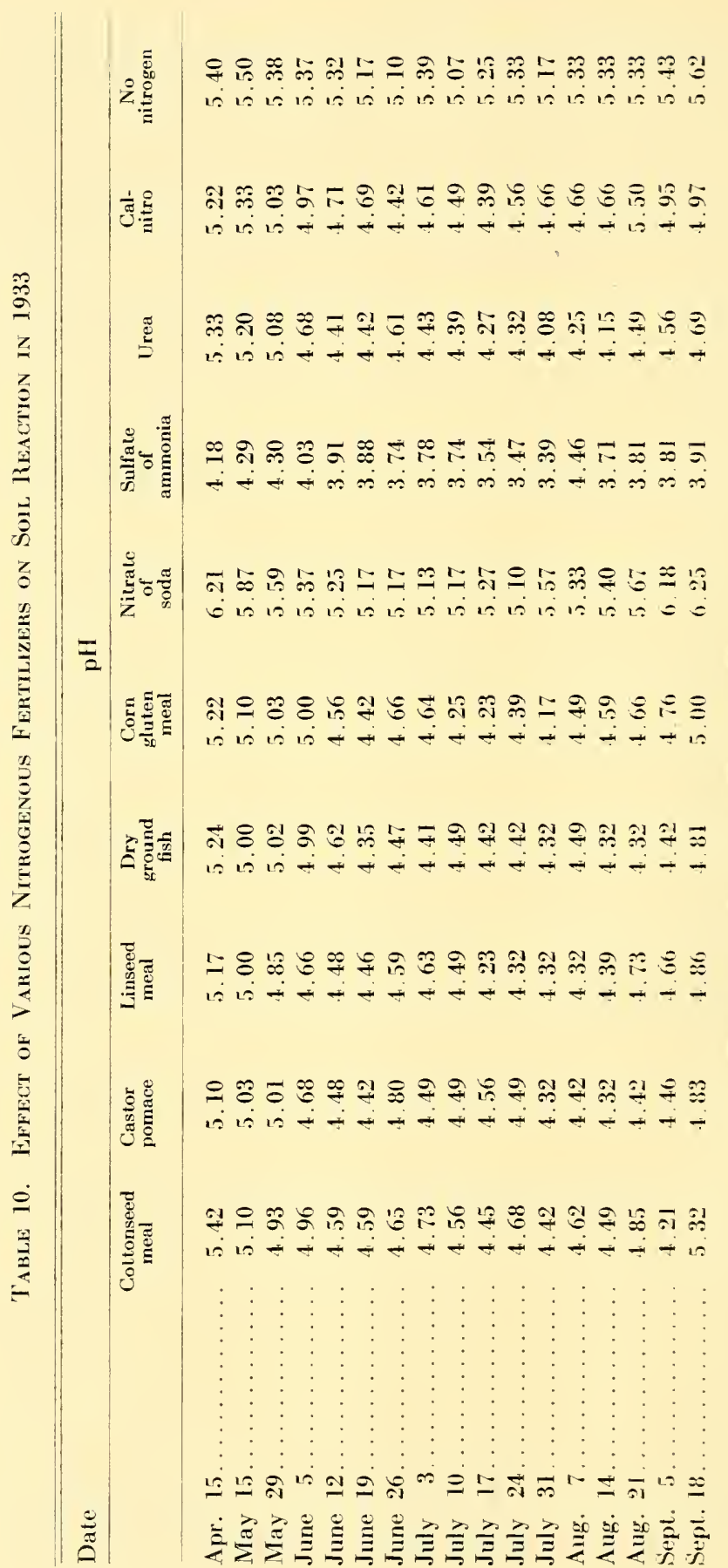




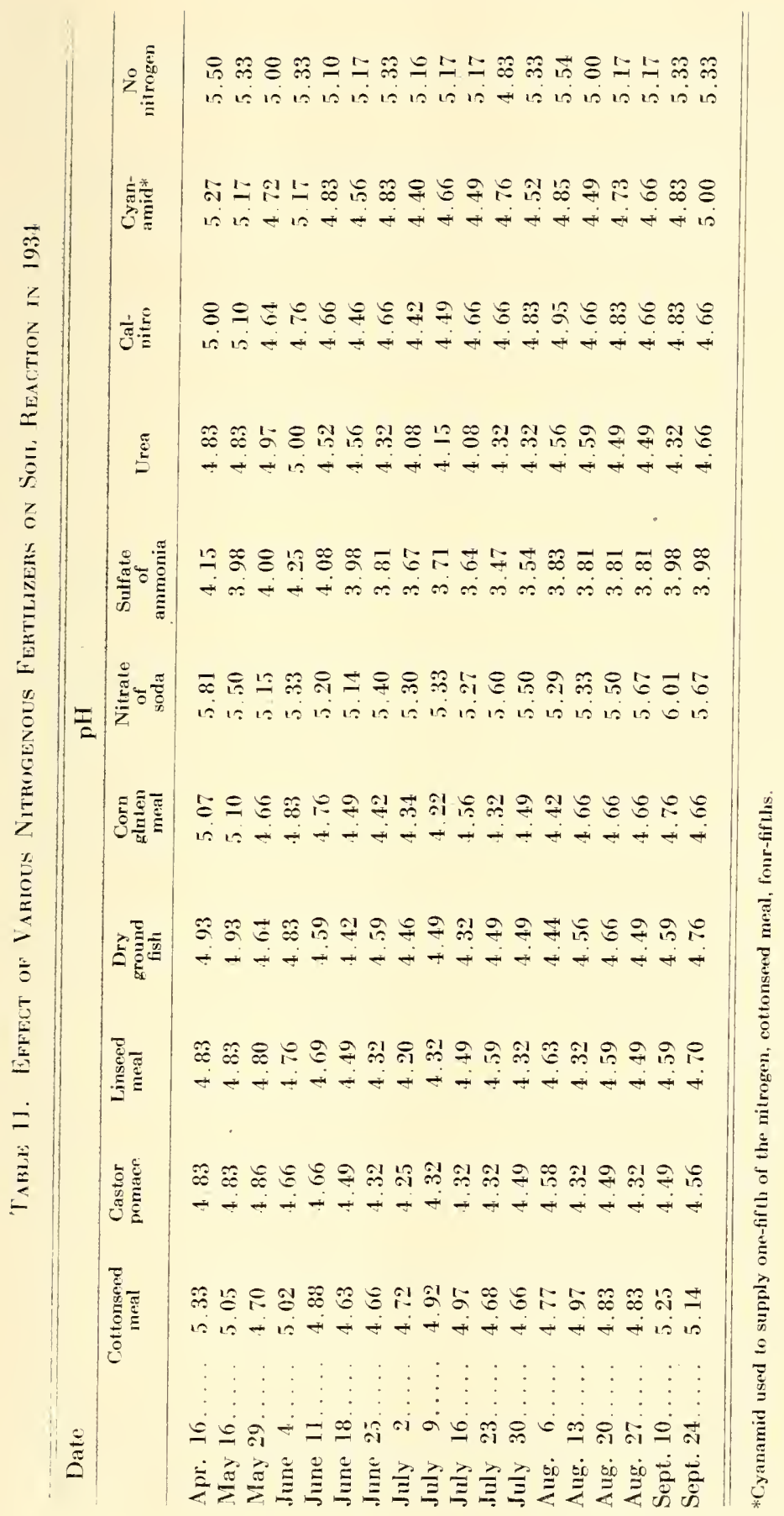




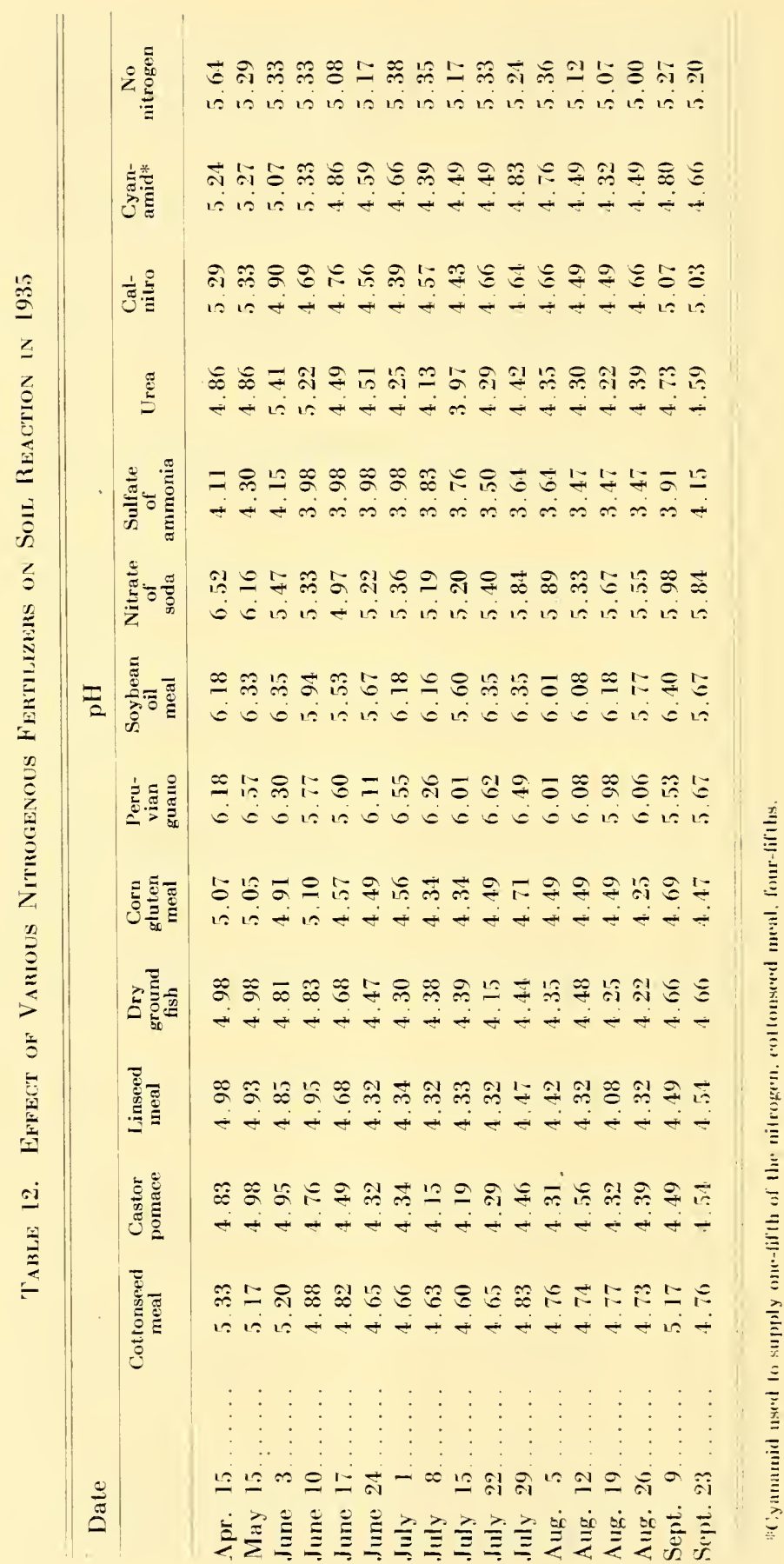


Effects of Nitrogenous Fertilizers:

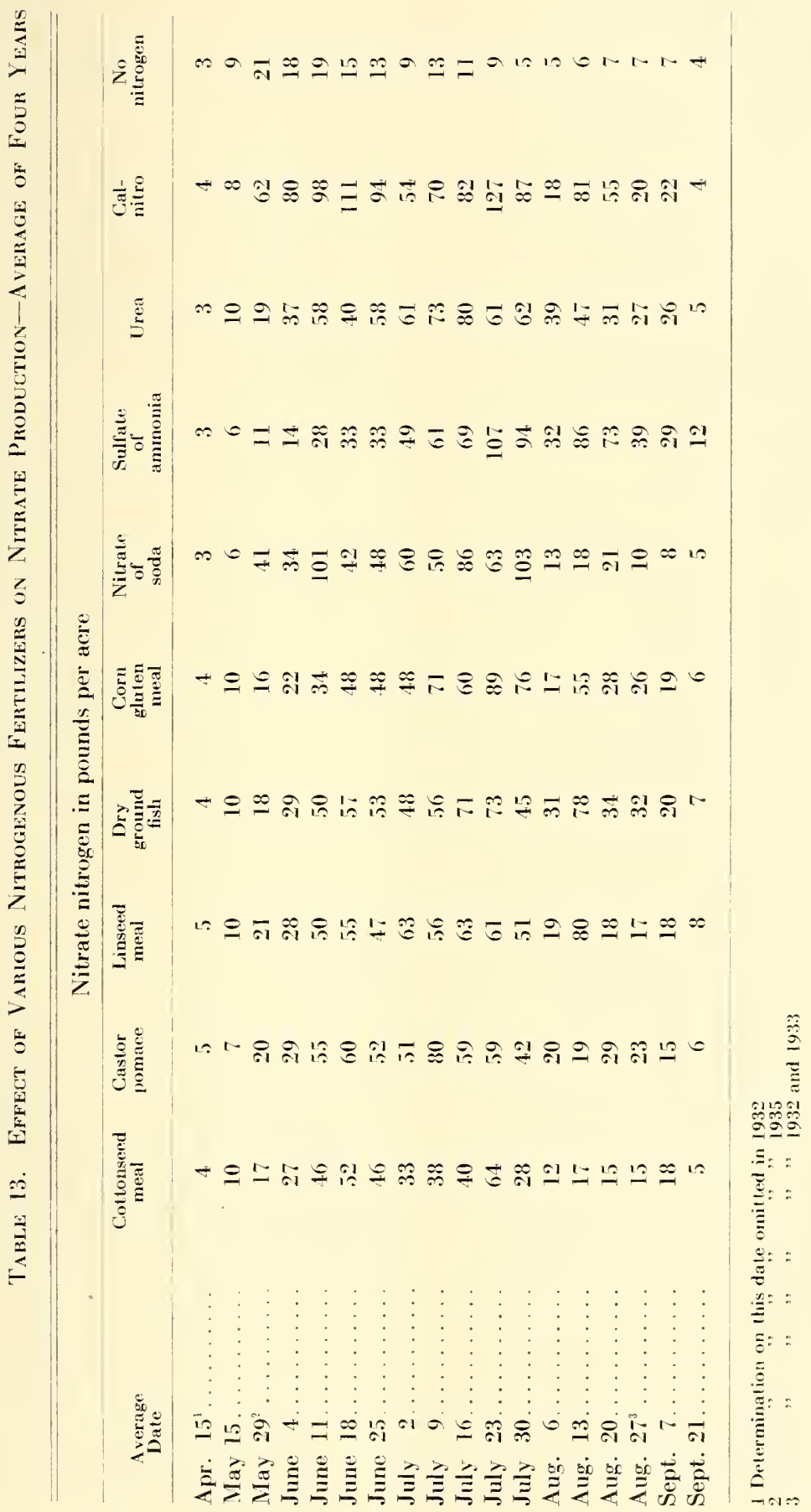




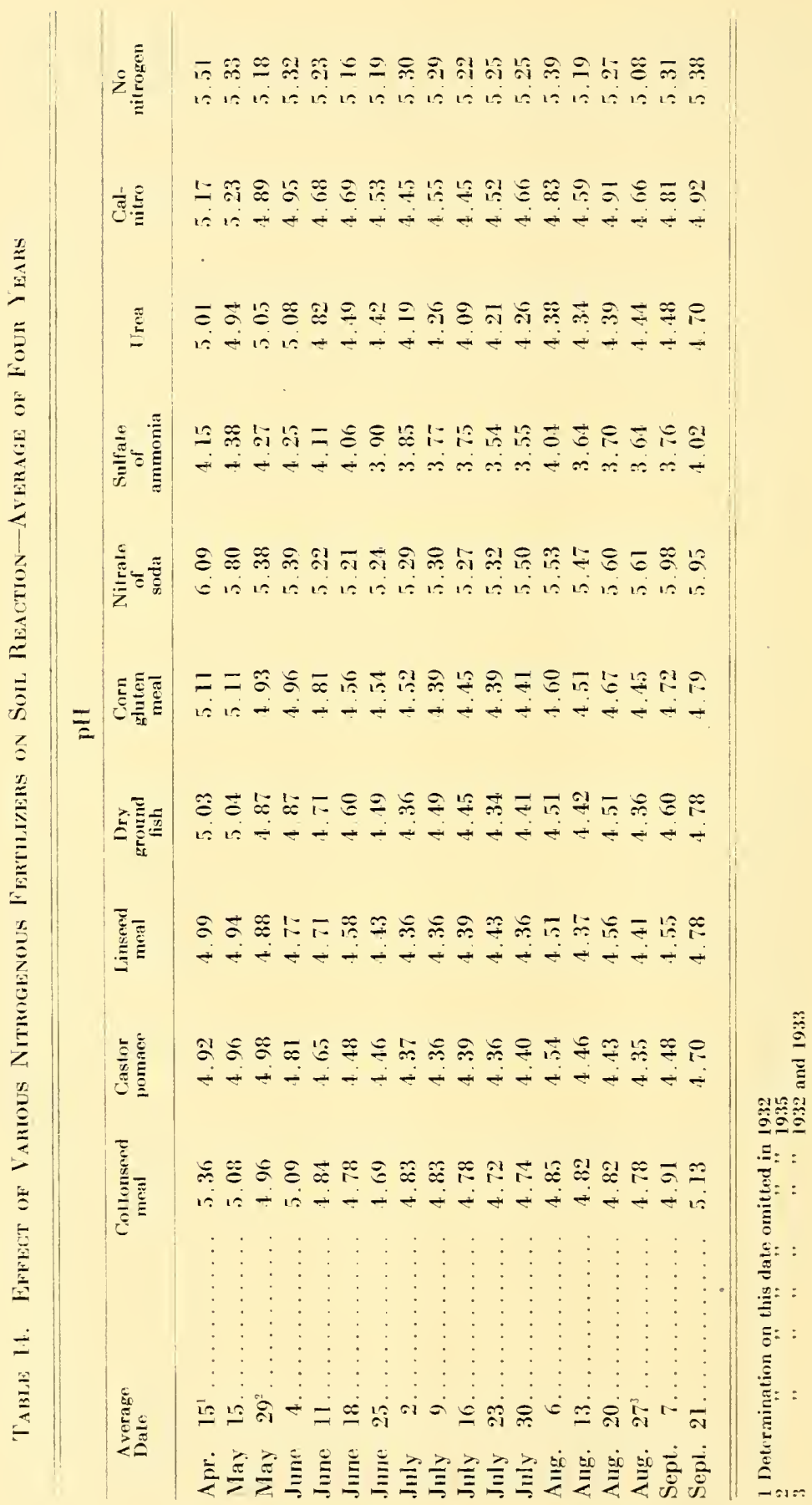


of the soil has proceeded at a very slow rate. Conditions by the middle of May are not greatly different and it is quite apparent that no reliance can be placed on residual nitrogen. Fertilizer applications are made dur-

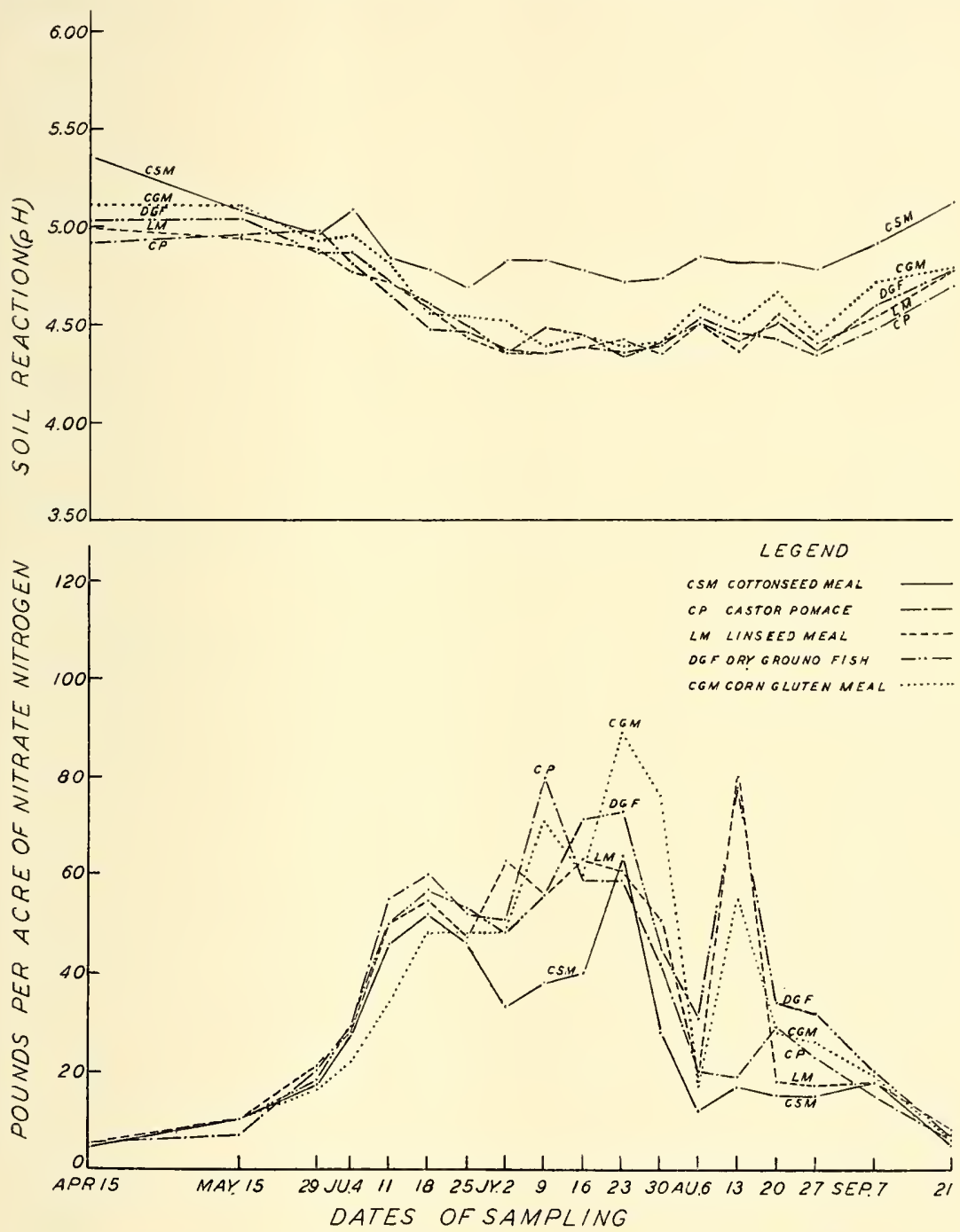

FIGURE 129. Graph showing average nitrate nitrogen and soil reaction levels of organic sources for the period 1932-1935.

ing the latter half of May and gradually make their presence felt by early June.

Maximum levels. The time at which nitrates reach their peak varies with the seasonal distribution of rainfall. A high point sometime during 
June occurred in each of the four years, ranging in date from June $13 \mathrm{in}$ 1932 and June 19 in 1933 and 1934, to June 24 in 1935. This level was not maintained, usually due to heavy rains, but in 1932 it was succeeded by a much higher peak in late July, and still another after the crop was off the field in August. In 1933, a rather low June maximum was not
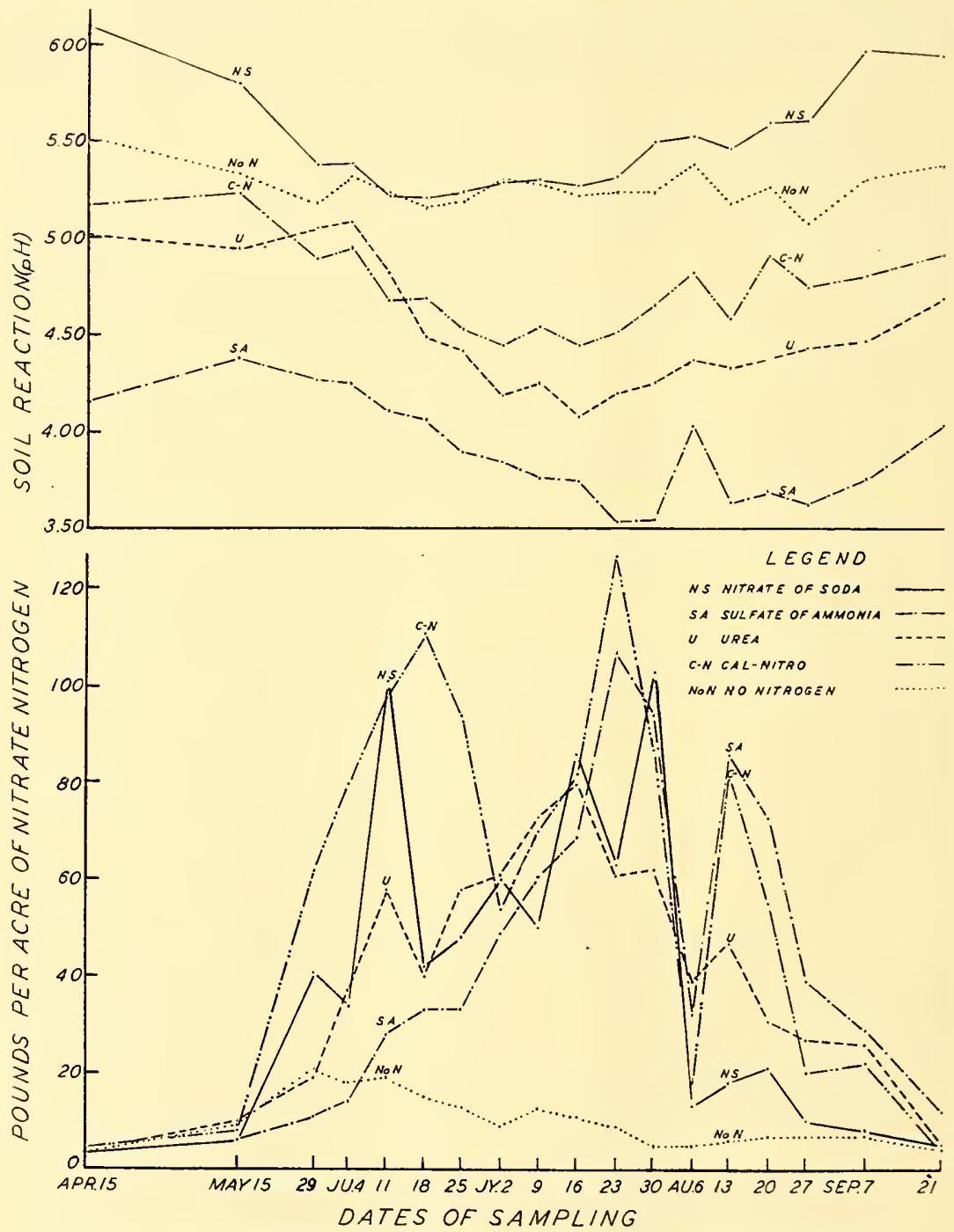

Figure 130. Graph showing average nitrate nitrogen and soil reaction levels of inorganic sources and no nitrogen for the period 1932-1935.

exceeded with any consistency, as steadily dry conditions and the increasing demands of the crop prevented any accumulation. I sharp drop occurred soon after the June maximum in 1934, with nitrates maintained 
at a lower level until July 16, when a still more severe reduction followed an irrigation equivalent to nearly two inches of rainfall. In 1935 the heavy rain of June 29 reduced the supply of soil nitrates sharply, while the succession of July rains allowed only occasional recovery. Thus in three of the four years, the early peak was not surpassed, a condition which can hardly be considered normal for our climate. It should be emphasized, however, that all weather is unusual under our climatic conditions. The record for the month of July, with an average rainfall of 4.35 inches for 64 years at the Hartford Station, shows extremes of 15.35 inches in 1897 and 0.54 inches in 1924 . In only 13 years of this entire period was the rainfall within one-half inch, plus or minus, of the mean. Thus it is idle to expect ideal rainfall distribution in any given period more often than once in five years.

Relative availability in relation to crop needs. The question of supply and demand in the nutrition of the tobacco plant is the ultimate measurement of the value of any material. Studies of the rate of growth and nitrogen assimilation ${ }^{1}$ of tobacco indicate that the plants take in an average of only 7 pounds of nitrogen to the acre during the first 30 days in the field. Subsequent assimilation is much more rapid with consequently heavier demands on the materials furnishing nitrogen. At the end of 50 days, 66 pounds have been used by the plant, and at 72 days, the average date of harvest, 114 pounds of nitrogen are present in the crop.

The first conclusion from these data is that early availability is not a prime requisite. Materials such as the nitrates, if used in a single application before setting, are in a precarious position due to danger of leaching. The plant is not able to use any considerable quantity until about July 1 , and it is to be noted that heavy rains almost always occur sometime during late June. Fractional application of these materials may be practiced, and has been followed with the nitrate of soda treatment beginning in 1933.

In the ordinary growth cycle of the tobacco plant, assimilation by the plant will usually exceed the available supply in the latter stages of the growing period. This is a desirable condition, as undiminished nitrogen intake delays ripening and tends to produce dark tobacco. Some materials, if used as sole sources, either produce nitrates too abundantly during the latter part of the growing season or have accumulated so much that the plant cannot use it all. Lnder unusual circumstances, nitrates are subject to this criticism. More frequently, however, this type of behavior is characteristic of sulfate of ammonia and to a lesser degree of urea. Vegetable organics are not apt to cause this trouble, but fish, as indicated by its average nitrate level on August 6 (Table 13 and Figure 129) is on the border line.

Among the organics, differences in maxima and general levels are not great. Slightly more favorable location of the linseed meal plot and one plot of castor pomace have been noted in previous reports. Fish and calnitro are also located in this tier (see diagram page 241, Bul. 335). Corn gluten meal has been moved since 1931 from this tier to a position on the upper part of the field, adjoining the nitrate of soda plot on the south.

1 Rates of grow th and Nitrogen Assimilation of Havana Seed Tobaceo. M. F. Morgan and O. E. Street Jour. Agr. lies. 51: 163-172, 1935 . 
Replications of the cottonseed meal and castor pomace plot, in that order. adjoin the sulfate of ammonia plot to the south. The cottonseed meal plot on the lowest tier, was moved in 1932 but returned in 1935 to its original position. Thus at the present time there is a cottonseed meal plot on each tier and a castor pomace plot on each of the two lower tiers. Over the four years under discussion in the present paper, a slight difference in soil type and topography operated to the disadvantage of cottonseed meal and perhaps corn gluten meal.

Taking into account these differences, the lowest level of nitrate nitrogen during the period the plant was in the field was maintained by cottonseed meal (Figure 129). Corn gluten meal started slowly, being the lowest until June 25, but thereafter the decomposition was as rapid as any other source. Post-harvest nitrification was rather high, but the drop at harvest was normal. Contrary to popular belief that linseed meal nitrifies slowly, it made a rather rapid start, maintained a good growing level, and dropped to a satisfactory point before harvest. Castor pomace behaved in a fashion closely paralleling that of linseed meal during the entire growing season, but resembled cottonseed meal in remaining at a lower level after the crop was removed. Dry ground fish had the highest average of the organic materials but was not appreciably ahead of linseed meal and corn gluten meal. As mentioned previously, it did not drop so sharply before harvest, and maintained the lighest late level. Among the inorganics only urea is worthy of note. The nitrate production of this material was greater than any of the organics, yet in the same order, and at a rate to produce a curve of the same type, (Figure 130). Furthermore, the ready decomposition of urea, as indicated by its rapid recovery after rains, perhaps justifies the use of less total nitrogen in the formula where this material is employed. The low post-harvest level of urea would indicate that the greater part of this material becomes available during the growing season.

New Materials. Three materials have been added to the test in the past two years, cyanamid in 1934, and soybean oil meal and Peruvian guano in 1935. Cyanamid was used to replace one-fifth of the fertilizer nitrogen on a cottonseed meal plot located on the southeast corner of the field. Peruvian guano and soy bean oil meal were located in that order in a tier north of the old plots. This latter area was occupied by an Adco manure plot from 1926 through 1931. It was used as a forest nursery in 1932 and 1933 with no fertilizer, and returned to tobacco in 1934 receiving a standard fertilizer furnishing 200 pounds nitrogen, three-fifths from cottonseed meal, one-fifth from castor pomace and one-fifth from nitrate of soda. No lime was added to the soil at any time since 1931.

A comparison of nitrate levels for the cyanamid-cottonseed mixture compared with cottonseed meal during the past two years indicates practically no difference.

The behavior of Peruvian guano and soy bean oil mealduring a single high rainfall year is not a good measure of their ultimate value. Both maintained nitrates at a distinctly higher level than cottonseed meal until after the heavy rain at the end of June. The subsequent production of nitrates by Peruvian guano was consistently lower than that of the cottonseed meal plot correspondingly located, while soy bean oil meal was con- 
sistently higher. The soy bean oil meal produced superior tobacco and seems to be a promising material.

\section{Rainfall in Relation to Nitrates}

The previous discussion of nitrate production has introduced most of the information necessary to an understanding of the importance of rainfall in nitrogen fertilization.

The presence of reasonable amounts of soil moisture is indispensable for the decomposition of organic fertilizers as well as urea or sulfate of ammonia. If the supply of soil water is so limited as to inhibit plant growth, it will also limit the production of nitrates through interference with biological activity in the soil. Such a condition prevailed during parts of 1934.

A review of the processes which organic fertilizers undergo before they become available to the plant is not amiss because of its fundamental importance in an understanding of the problem of nitrogen fertilization of tobacco. There are three major steps in the process of nitrification, the nitrogen being changed from the organic forms, first into ammonia salts, second into nitrites and third into nitrates. In each of these steps a specific class of bacteria performs a distinct function. The final product in the case of any material is a nitrate of potassium, calcium, magnesium, sodium or even ammonium. Urea and sulfate of ammonia are already intermediate compounds and hence should be more readily available. It is only in the form of nitrates that the plant is able to assimilate any appreciable amount of nitrogen. Therefore, imless the proper conditions of temperature and moisture prevail, the plant will suffer from lack of nitrogen.

Nitrate salts, either produced by nitrification or applied directly, are at once the most available to the plant and the most readily removed from the soil by heavy rains. An examination of Figure 131, which shows the nitrate levels for nitrate of soda, urea, dry ground fish and cottonseed meal in 1932, and the rainfall during the season, amply illustrates this point. The fertilizer application was made between the determinations of May 16 and May 31, and in that year the nitrate of soda was all applied at one time. Nitrification occurred at a reduced rate until a rain of threequarters of an inch on June 12 stimulated activity. $U_{p}$ to this date, there was insufficient moisture even to dissolve the nitrate of soda and diffuse it in the soil evenly enough to secure a true sample. The other three materials doubled their production of nitrates within a week. Heavy rains, 1.61 inches, on Jume 16 and 17 , promptly reduced the nitrate supply in the surface soil and until the middle of July the accumulation was very gradual. Rainfall was sub-normal in this period, only 1.30 inches until July 17. A total of 1.13 inches in three rains within the next 8 days caused renewed activity of all materials, and the peak for the season was reached on July 25. During the following two weeks, rains of $1.78, .45, .70$ and .24 inches produced leaching on all treatments and the nitrates practically all moved out of the surface soil. Harvesting the crop about August 10 ended the drain on the nitrates from that source, but only dry ground fish showed an immediate response, the others remaining low at this 
point. A temporary revival in early September found the fertilizers with only a limited supply of readily nitrifiable material, and heavy rains soon brought about the almost entire disappearance of soil nitrates.

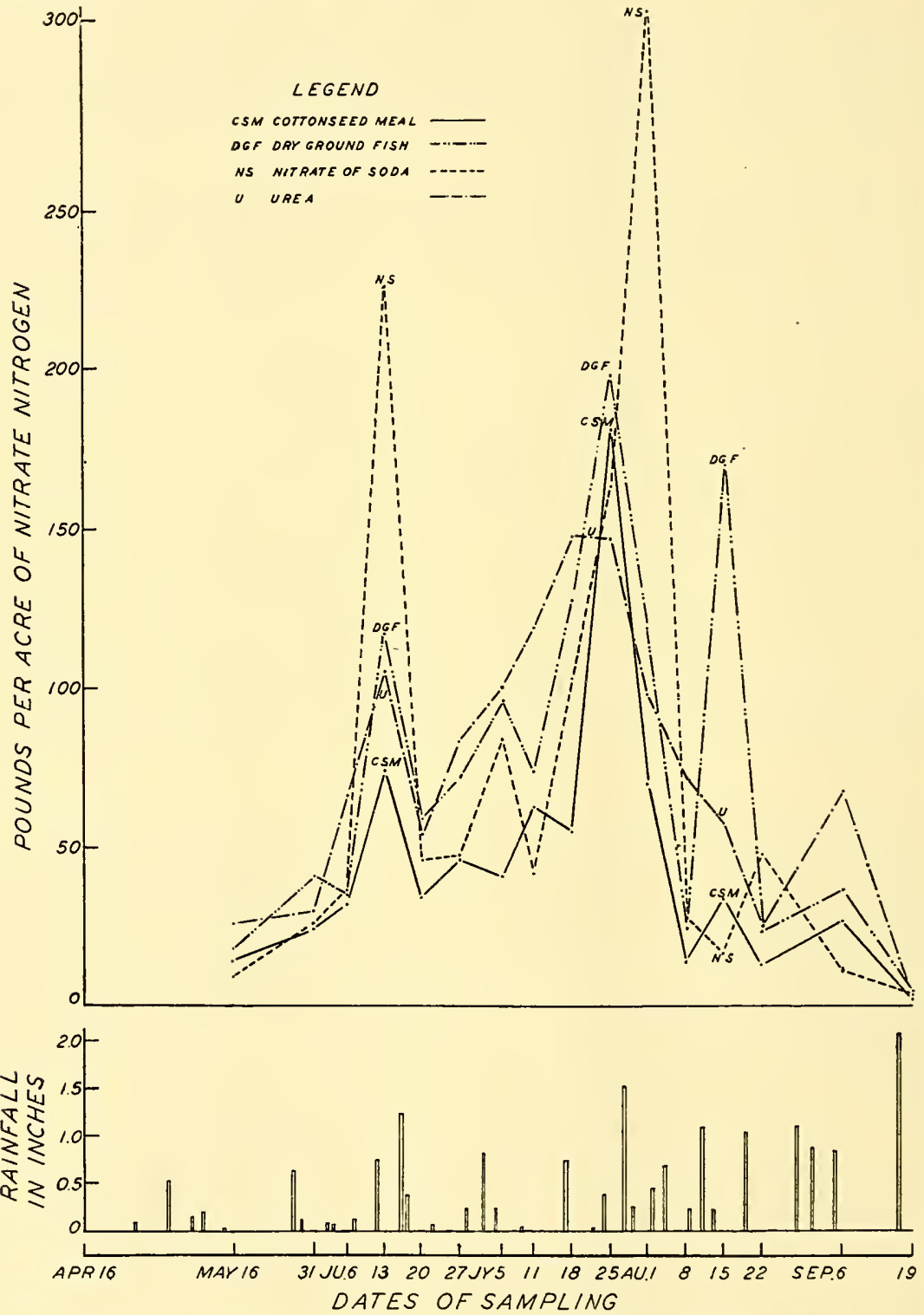

Figure 131. Graph showing nitrate nitrogen production in relation to rainfall in 1932. Nitrate of soda applied all at one time in late May.

A similar study of the same materials in 1934 is shown in Figure 132. Nitrate of soda was applied in five equal lots on May 21, June 2. 12, 20 

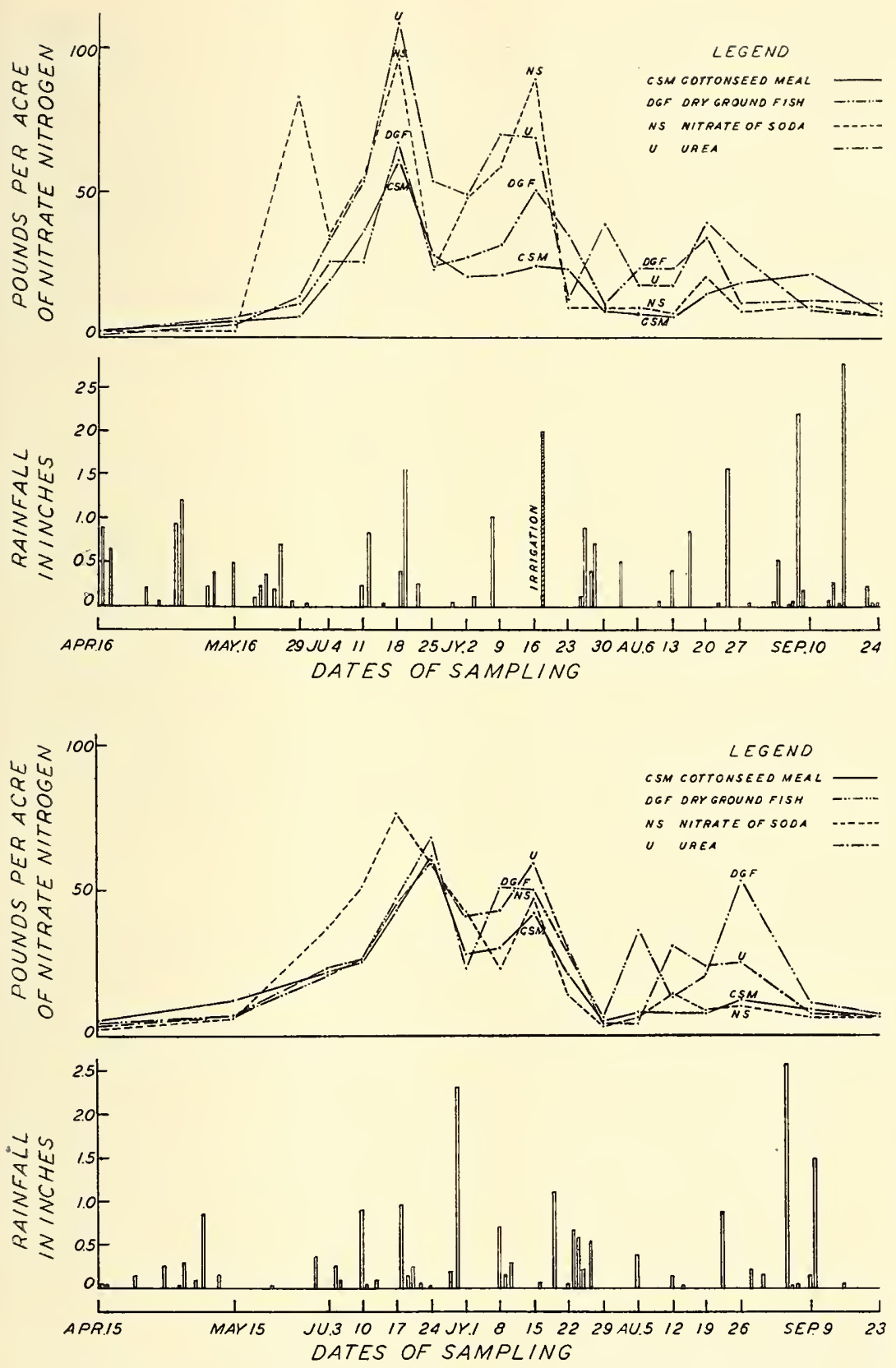

FigURE 132. Graph showing nitrate nitrogen production in relation to rainfall and irrigation in 1934 (above) and to rainfall alone in 1935

(below). Nitrate of soda applied in five equal amounts from late May to early July. 
and July 2. Heavy rainfall before the fertilizer was applied kept nitrates very low and the increase was not marked until .82 inch fell on June 12. Determinations on the eighteenth indicated a rapid increase, but this was quickly lost in the following week, when 2.35 inches of rain were recorded. Aided by an inch of rain on July 7 , urea gained quite rapidly up to July 16, while nitrate of soda, with the final 40 pounds of nitrogen applied on July 2, rose to a fairly high level. Fish gained less rapidly than urea. while cottonseed meal was only able to maintain its level of July 2. An irrigation on July 17, equivalent to 2 inches of rain, brought a rapid drop in all cases. Added to this was a natural rainfall of more than 2 inches between July 26 and 28, and a partial irrigation which was interrupted by the rain, and the soil nitrates were out of reach of the plant roots. Urea and fish regained a low level in the middle of August, but excessive fall rains soon dissipated these gains.

The nitrate levels in relation to rainfall for 1935 are also shown in Figure 132. This year found the lowest levels of any year studied, a condition almost equally true for all materials. Nitrate of soda was again applied in five equal amounts but failed to make any proportionate response. Early nitrate levels were low, but unlike 1931, this was not due to too much rainfall. In fact, the low level of nitrates early in 1935 was due to too little rainfall, which did not permit decomposition of the cottonseed meal, fish or urea, and even the nitrate of soda was not sufficiently dissolved to get a true sample. Then almost as soon as nitrification had made a good start as a result of moderate June rains, a very heary rain. 2.30 inches on June 27 , reduced the level to the danger point. Late July rains brought the level below 10 pounds to the acre and the crop was actually starved during the remainder of the growing period. Fish made a fair post-harvest recovery, but the damage had been done.

Speed of recovery after rains. It is noticeable that the four materials, each representing a different class of compounds, behave quite differently following rains. Nitrate of soda fluctuates widely, in part due to sampling error, but mainly due to the ease with which it is translocated by rain water. A moderate rain, up to an inch,will move the nitrates down only a few inches, provided the soil is not already saturated. With the onset of drier weather, the nitrates will return with the capillary water and again become available to the plant. Heavy and persistent rains will soon carry nitrate of soda into the drainage water and the loss is then complete. At this point it should again be emphasized that other nitrate salts, such as nitrate of potash or nitrate of lime, behave similarly. as do all the nitrates formed by the complete decomposition of organic or intermediate materials. Fortunately other materials decompose over a considerable range of time, and unless they have heen nitrified, they do not leach readily.

It is apparent that cottonseed meal regains its nitrate level very slowly after heary rains. Fish decomposes more rapidly and urea still more so. perhaps twice as fast as cottonseed meal. The practice of side dressing after leaching rains is only valuable if nitrates are used, other materials serving only to increase the ease of application. 


\section{Soil Reaction as Influenced by Nitrogenous Fertilizers}

The acidic character of nearly all the materials used for nitrogenous fertilization of Connecticut tobacco is not widely recognized. Among the fertilizers used in this test, only nitrate of soda may be considered neutral. Calnitro, a mixture of ammonium nitrate and calcium carbonate, might seem to be in the same class, but it is moderately acidic. Organic materials produce a greater excess of acid ions in their decomposition than is commonly supposed, and are classed as moderately acidic. Crea, by its decomposition into nitrates and carbonates or unstable bicarbonates, is rather strongly acidic, but not as much so as sulfate of ammonia, which rapidly depletes the soil of all soluble bases.

No lime has been added to the original plots since the experiment was started in 1926. The block of plots added in 1929, castor pomace, linseed meal and dry ground fish, was on an area not previously in tobacco, as was cahnitro, added in 1930. Corn gluten meal, and the second replication of cottonseed meal added in 1932, were on unlimed potash plots. The second replication of castor pomace and the present cyanamid plot are on old potash plots which were limed in1931 at the rate of 1000 pounds of hydrated lime per acre. However, the $\mathrm{pH}$ data for the limed castor pomace plot are not included in the tables, even though the present difference is not great. The Pernvian guano and soy bean oil meal plots are located on an old Adco manure plot, which had proved to be almost as basic as stable manure; consequently the soil reaction data are not comparable to the older parts of the field. An application of 500 pounds of land plaster per acre to the older parts in the fall of 1933 was the only soil amendment made during the 10 years of the experiment.

Results of soil reaction studies on these plots have been reported in Tobacco Station Bulletin 10, Report for 1927; Conn. Agr. Expt. Sta. Bul. 311, Report for 1929; and 306 published in 1929. In the last-named, pages 796-797, may be found a study of the effect of various fertilizer's on the soil reaction. Bulletin 311, pages 264-268. discusses the seasonal fluctuation of soil reaction for these plots from May, 1926, to December, 1929.

At the time nitrate measurements were started, the soil on most of the plots was already rather strongly acid. Sulfate of ammonia has become much too acid to produce good tobacco, as indicated by $\mathrm{pH}$ readings of 3.50 and lower during the summer. Urea has dropped quite markedly from 1927 measurements, while all the organic materials are somewhat lower. Nitrate of soda has not changed the soil reaction greatly during the past 10 years. The data for no nitrogen are a good index of the normal behavior of this soil. As may be seen from Figure 130 and Table 14, the absence of nitrogenous fertilizer results in an equilibrium between $\mathrm{pH}$ 5.00 and $\mathrm{pH} 5.60$ which does nol vary from year to year.

Seasonal fluctuation in relabion to nitrates and rainfall. All measurements of soil reaction indicate a maximum of soil acidity sometime during the growing season. This usually corresponds with the maximum of soil nitrates, but does not necessarily coincide with it. The presence of other acidic materials such as sulfates usually leads to a gradual lowering of pH readings until late summer. The cumulative effect of the acid ions does not entirely disappear until heavy and persistent rains have carried out of the soil most of the other acidic materials as well as the

\footnotetext{
1 See also Conn. Agr. Fxp. Sta. Bul. 384. Soil Changes Resulting from Nitrogenous Fertilization.
} 
nitrates. An indication of this fact is to be found in the lower $\mathrm{pH}$ readings in late September as compared to April. Nitrates have practically disappeared by late September, but subsequent removal of other acidic ions causes a further rise in $\mathrm{pH}$ readings of from .10 to $.30 \mathrm{pH}$ unit.

Fluctuations caused by the fertilizer material. A detailed examination of Tables 9 to 12 shows wide fluctuations in soil reaction for any one material during the period of measurement. The range was most extreme with nitrate of soda and urea, differences as wide as 1.55 and 1.44 $\mathrm{pH}$ units being recorded in 1935 for the two materials. The range as indicated by the four-year averages, was greater for inorganic than for organic carriers, but the least for no nitrogen. Differences in range between the organic materials were negligible, with dry ground fish and corn gluten meal showing the slightly wider ranges. No correlation with the range of nitrate determinations was apparent. It is quite obvious that a general positive relation between nitrification and soil acidification exists, but is not subject to detailed agreement.

\section{Conclusions}

From the data presented, the following conclusions may be drawn:

Soil nitrate levels vary widely as a result of the interaction of factors favoring the accumulation of nitrates - such as high temperatures and adequate moisture with the factors favoring their removal, such as heavy rains and rapid plant growth.

Relative availability of organic materials in relation to plant needs indicate that all of those tested are about equally valuable. Rapidity of decomposition is in the following increasing order: Cottonseed meal, corn gluten meal, castor pomace, linseed meal, dry ground fish.

Inorganic materials range from immediately to slowly available. Nitrates are subject to too ready leaching, while sulfate of ammonia produces abundant nitrates but is objectionable because of its acid character. Urea is a very good source of fertilizer nitrogen.

Among new materials, soybean oil meal seems very promising.

The relation of rainfall to nitrates is discussed. Moderate rains, of not more than an inch per week, greatly stimulate nitrification. Heavy or persistent rains, of two or more inches in a short period, cause a heavy loss of soil nitrates.

Speed of recovery after rains varies with the class of material. Vegetable organies are the slowest followed by animal organics and urea.

Soil reactions determined concurrently indicate the acidic character of all materials used except nitrate of soda. Seasonal fluctuations averaged $.67 \mathrm{pH}$ unit for organic materials, $.85 \mathrm{pH}$ unit for inorganic, and $.13 \mathrm{pH}$ unit for no nitrogen.

\section{FURTHER FERTILIZER EXPERIMENTS WITH COTTONHULL ASHES}

In a previous publication (Conn. Sta. Bul. 334: 207-210. 1932) the writers described preliminary experiments on the use of cottonhull ashes as the source of potash in the fertilizer mixture. Results up to that time did not indicate any improvement in yield or grading from the substitution of cottonhull ashes for other carriers of potash, but the need of further tests before drawing conclusions was stressed. 
Since many growers reported good success with a formula made up only of cottonhull ashes and cottonseed meal, a new series of field tests was started in 1932 in which such a formula was to be compared with a standard formula supplying the same quantity of nutrient elements but with the potash derived equally from sulfate and carbonate.

The formulas were as follows:

\section{Cottonhull ash formula (K16)}

3000 lbs. cottonseed meal

560 lbs.* cottonhull ash $^{*}$

\section{Formula without cottouhull ash (K17)}

3000 lbs. cottonseed meal

109 lbs. carbonate of potash

146 lbs. sulfate of potash

93 ibs. magnesian lime

49 lbs. precipitated bone

Each formula supplies 200 pounds of nitrogen, 109 pounds of phosphoric acid, 200 pounds of potash, 49 pounds of magnesia and about 75 pounds of calcium oxide to the acre.

The test has been continued for four years on eight plots, each onetwenty-fifth acre in size, with the four cottonhull ash plots alternating side by side with the control plots (without cottonhull ash). These plots are located on field I on a medium heavy soil that does not leach much or suffer from drought and naturally produces a high yield of tobacco. The soil is uniform except that in 1933 a "dead furrow", in which the water settled and drowned the plants, upset the data on one plot (K17) and the effect was still visible in the two following years. Each season the fertilizer was applied about 10 days before setting. Havana Seed plants were set during the first week in June and all cultural operations were uniform. The harvested tobacco hung in the same tier in the curing shed, was taken down and stripped at the same time and sorted in the Station sorting shop.

During the entire four years, close observation in the field failed to show any differences between the plots with respect to size, habit of growth, appearance, or maturity of the plants.

Observations on the cured tobacco as it was sorted showed that all plots produced a good quality and there was little choice between them. During one year, however, it was our impression that the tobacco from the cottonhull ash plots was a little smoother, with less prominent veins. This was reflected in the sorting records by a somewhat larger percentage of the grade, "light wrappers".

A summary of the yields and the grade indices for the four years is given in Table 15. This shows that the yield per acre on all plots is almost the same. In fact it is almost identical if plot K17 (damaged by dead furrow) is omitted. It is apparent, then, that no increase in yield may be expected from the use of cottonhull ash.

*Amount changed each year according to the percentage of potash found in the ashes. 


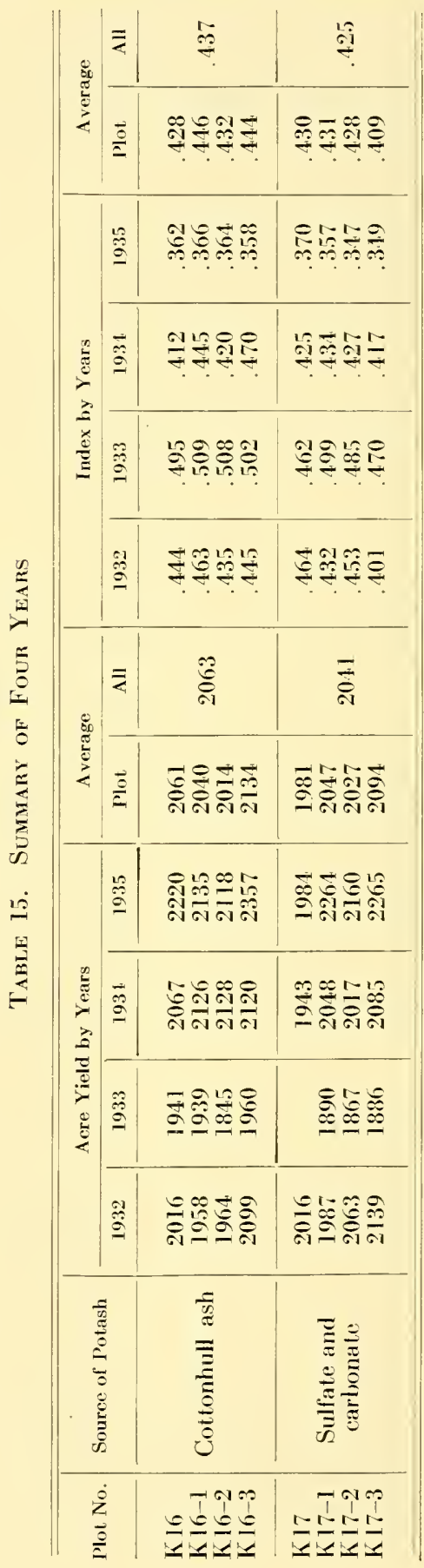


Considering the grade index figures, it appears that there has been a small but rather constant difference in favor of the cottonhull ash tobacco. Whether this difference is large enough to be significant is mathematically questionable. The most we can conclude from this series of tests is that the use of a formula composed of cottonhull ashes and cottonseed meal has produced very excellent tobacco which is just as good, or possibly a little better, than that grown with a similar formula where other sources of potash are substituted.

Effect on the soil. Since this material contains considerable quantities of alkaline salts (potash, lime, magnesia), there has been some apprehension lest the continuous use of cottonhull ashes over a series of years on the same field might make the soil alkaline, or result in an unfavorable accumulation of salts. In order to see whether such effects could be detected after four years of treatment with 500 to 600 pounds of ashes annually, soil samples from each of the eight plots, taken in November of the fourth year, were analyzed. There was no significant difference in the amount of potassium, calcium, magnesium, phosphorous or nitrogen, as between the cottonhull ash plots and the control plots. The use of ashes, therefore, has not resulted in any greater accumulation of these salts in four years.

However, there has been some decrease in acidity. Each cottonhull ash plot tested somewhat higher $(\mathrm{pH})$ than its adjacent control. In November, 1935, the average reaction of the ash plots was pH 5.07 and of the controls was $\mathrm{pH} 4.91$. Such an increase in reaction, however, is not injurious on this field and would not be dangerous except on soils that naturally have a high reaction.

Effect on the burn. In order to see whether cottonhull ashes have any specific effect on the burn of tobacco, both strip tests and cigar tests were made.

The object of the strip test is to determine the fire-holding capacity of the leaf when a single leaf is stretched between the two hands. The leaf is ignited from an electrically heated wire coil and the duration of combustion (until last glow disappears) determined with a metronome. Twenty tests of the "seconds" and twenty of the "darks" (fermented crop of 1933) from each plot were made, making a total of 160 tests for each treatment. The average duration of burn for all tests on the cottonhull ash tobacco was 41.5 seconds; for the control formula it was 43 seconds. The difference between them is too small to be significant and thus there is no indication here that the use of cottonhull ashes has had any influence on fire-holding capacity.

As a further comparison, 50 cigars were wrapped with leaves from the cottonhull ash plots and another 50 from the check plots. These were smoked in pairs by a considerable number of smokers. No consistent differences were observed in color or coherence of the ash, width of coal band or in the taste and aroma of the cigars.

Effect on chemical composition. Cottonhull ash is used chiefly to supply potash but it also supplies calcium and magnesium. In order to see whether the tohacco plant absorbs more of any of these bases from the cottonhull ash formula than from the check formula, samples of two 
grades, seconds and darks, were analyzed from each of the eight plots. The average content of bases from all plots is shown in Table 16.

Table 16. Percentage of Bases in Tobacco from Cottonhull Ash Plots and Adjacent Check Plots.

\begin{tabular}{lcccc}
\hline \hline Fertilizer & Total ash & $\begin{array}{c}\text { Potash } \\
\mathrm{K}_{2} \mathrm{O}\end{array}$ & $\begin{array}{r}\text { Lime } \\
\mathrm{CaO}\end{array}$ & $\begin{array}{r}\text { Magnesia } \\
\text { MgO }\end{array}$ \\
\hline Cottonhull ashes & 17.84 & 4.23 & 6.03 & 1.95 \\
No ashes & 17.76 & 4.43 & 5.63 & 2.06 \\
\hline
\end{tabular}

It appears from these analyses that the basic content is not significantly changed by the use of cottonhull ash.

\section{FUR'THER INVESTIGATIONS ON THE USE OF FERTILIZER MAGNESIA}

Work on magnesia in tobacco fertilization has been carried on for a number of years at this Station. The latest extensive report of results is found in our annual report for 1932 (Conn. Agr. Exp. Sta. Bul. 350). In the following pages we include further studies on the effect of magnesia on yield, grading and chemical composition; estimation of soil magnesia and its relation to crop needs; as well as a discussion of conditions governing the color of ash. In addition, results are given on tests with a neutral magnesium salt, an anhydrous magnesium sulfate.

\section{Color of Ash}

Experienced cigar smokers frequently correlate the taste with the appearance of the ash on the cigar. A dark or muddy ash in most cases is associated with poor taste and aroma, wlile good cigars produce lighter colored ashes.

An excessive amount of potash in tobacco makes a dark ash, and the color is roughly proportionate to the excess of this element in comparison to other bases. The dark color of the ash is due to the presence of unoxidized particles of carbon (charcoal); i.e. the color range - white, through gray to black-indicates the degree of combustion. A high content of potash causes incomplete combustion, since potassium salts have a tendency to fuse and enclose the carbon particles, thus excluding the air and preventing oxidation.

Since the gaseous products of incomplete combustion are less pleasant to the taste and smell than those of complete combustion, it follows that the darker the ash color, the less pleasant the taste and aroma.

Previous investigations at this Station have shown that the dark color due to excess potash may be changed to a desirable light color by iucreasing the magnesia, the compounds of which do not fuse when burned but produce a porous ash that permits more complete combustion.

Then there is the familiar muddy or brick-colored ash which frequently appears on cigars, irrespective of brands. The cause of this condition 
has been revealed only recently. A study of the carbonates or oxides (which constitute the ash) led us to believe that manganese compounds may be a contributing factor in discoloring the ash, since there was a resemblance in color between certain manganous compounds and the brick-colored ash.

Samples of tobacco, known to produce brick-colored ash when wrapped on a cigar, together with samples producing desirable grayish ash, were analyzed with respect to their manganese content. The results are given in Table 17.

Table 17. Content of Manganese (as $\mathrm{MN}_{3} \mathrm{O}_{4}$ ) in Cigar Leaf Tobacco and Color of Ash. Air Dry Basis

\begin{tabular}{|c|c|c|}
\hline Sample No. & $\% \mathrm{Mn}_{3} \mathrm{O}_{4}$ & Ash color \\
\hline 1 & .023 & Light gray ash, no brick color \\
\hline 2 & .034 & 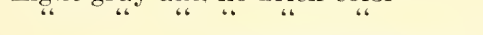 \\
\hline 3 & 047 & " " " " very slight brick color \\
\hline 4 & .057 & Gray ash with slight brick color \\
\hline 5 & .064 & 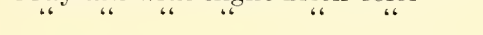 \\
\hline 6 & .067 & $\begin{array}{llllll}6 & 6 & 6 & 6 & 6 & 6\end{array}$ \\
\hline 7 & 081 & $\begin{array}{llllll}6 & 4 & 6 & 4 & 6 & 6\end{array}$ \\
\hline 8 & .277 & Very heavy brick color \\
\hline 9 & .302 & 660606 \\
\hline
\end{tabular}

From this table it may be concluded that brick-colored or muddy ash may be prevented when tobacco contains less than .04 per cent $\mathrm{Mn}_{3} \mathrm{O}_{4}$. How is it possible to avoid the brick-colored ash? A previous study* of manganese in Connecticut soils showed that active manganese in the soil increases as the soil becomes more acid, i.e. below $\mathrm{pH} 5.0$ we may expect the soil to contain sufficient active manganese to influence seriously the color of ash.

With respect to the samples in Table 17, it should be stated that samples 1 to 6 were grown on soils with a reaction ranging from $\mathrm{pH} 5.40$ to $\mathrm{pH}$ 6.15, while samples 7 and 8 were derived from soils with $\mathrm{pH}$ values of 4.90 and 4.45 respectively. The remedy then is to raise the reaction of the soil enough to inactivate the manganese, which is accomplished by liming.

Although calcium is the active element governing the absorption of manganese $^{* *}$, magnesian lime may be used in liming an acid tobacco soil, since such a soil is usually also low in magnesia.

Finally, there is the light gray to whitish ash which in extreme cases will flake, thus lacking in coherence. This latter condition, as has been fully discussed in our report for 1932 (Comn. Agr. Exp. Sta. Bul. 350) is caused by the presence of too much magnesia as compared to other bases. The work at this Station has been continued on the problem of determining the proper quantities of magnesia to apply to tobacco soils for obtaining a desirable ash. The latest results are reported below.

* H. G. M. Jacobson and T. R. Swanback. Manganese content of certain Connecticut soils and its relation to the growth of tobacco. Jour. Amer. Soc. Agron. Vol. 24: 237-245, 1932.

**Hans Burström. Über antagonistische Frscheimngen bei der Kationenaufuahme des Hafers. Upsala, 1934 . 


\section{Annual Applications of Magnesian Lime}

In our previous experiments, reported in 1932 (see above) one-time applications of magnesian lime were made and in succeeding years the duration of effects of the treatments observed. It was concluded from these results that long time residual effects could not be depended on, but anmual application of not more than 100 pounds magnesium oxide to the acre should be applied. In order to determine more definitely the size of the annual application, experiments were begun in 1933 with a set of one-fortieth acre plots, formed by dividing the plots crosswise of the original lime series, and treated as follows:

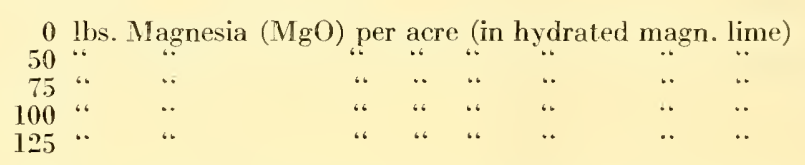

All plots received general fertilizers, composed of cottonseed meal, castor pomace, nitrate of potash and sulfate of potash to equal about 200 pounds nitrogen and 200 pounds potash per acre.

Effect on yield and grading. There are no conspicuous differences to be found in the results from the various amounts of magnesia applied in regard to yield and grading, which may be learned from the three-year summary in Table 18. It is obvious that from a practical standpoint, moderate additions of magnesian lime to tobacco land will not alter the yields or appearance of the tobacco grown on it. Smoke tests and the chemical composition of the leaf, however, may reveal other qualities.

Table 18. Yield and Grading Records of Magnesia Plots. Summary of Three Years Results, 1933-1935 (Quantitative Series)

\begin{tabular}{|c|c|c|c|c|c|c|c|c|}
\hline \multirow{2}{*}{$\begin{array}{l}\text { Pounds } \mathrm{MgO} \text { per } \\
\text { acre annually }\end{array}$} & \multicolumn{4}{|c|}{ Yields per acre } & \multicolumn{4}{|c|}{ Grade index } \\
\hline & 1933 & 1931 & 1935 & Av. & 1933 & 1934 & 1935 & Ar \\
\hline 0 & 1655 & 1918 & 1984 & 1852 & .535 & .430 & .383 & .449 \\
\hline 50 & 1710 & 1917 & 2032 & 1886 & .550 & .431 & .358 & .446 \\
\hline 75 & 1703 & 1840 & 1988 & 1844 & $.53 \overline{5}$ & +18 & .313 & .432 \\
\hline 100 & 1823 & 2036 & 1983 & 1947 & .568 & .424 & .335 & 442 \\
\hline 125 & 1862 & 1961 & 1947 & 1923 & .543 & 426 & .337 & $43 \overline{5}$ \\
\hline
\end{tabular}

Smoke Tests. For the purpose of observing the effect on the ash color, leaves from tobacco grown with the various quantities of magnesia were wrapped on cigars, which were then smoked. It was noticed that tobacco from the check plots, where no magnesia other than that incidentally introduced through the organic materials had been applied to 
the land, produced a dark, muddy ash, with bad, sharp taste. With the 50-pound application, a lighter ash was obtained but still a slight brick color adhered to it. The 75-pound application produced as nearly a perfect ash as could be desired-a very light gray to whitish, without flaking and with no objectionable taste and aroma. Similar results followed from the use of 100 pounds, although a tendency to flakiness occurred. The highest application (125 pounds) produced an ash that was altogether too flaky.

From the results of these tests, it is evident that an annual application of about 75 pounds of magnesia in the form of magnesian lime would be a suitable amount.

Chemical Analyses. Samples of tobacco grown on these plots during 1933, 1934 and 1935 were analyzed with respect to content of magnesia. The results are slıwn in Table 19.

Table 19. Content of MgO in Tobacco Leaves of 1933, 1934 and 1935 Crops. Air Dry Basis

\begin{tabular}{|c|c|c|c|c|c|c|c|}
\hline \multirow[b]{2}{*}{$\begin{array}{l}\text { Lbs. MgO } \\
\text { per acre }\end{array}$} & \multirow[b]{2}{*}{$\begin{array}{c}\text { Grade } \\
\text { of } \\
\text { tobacco }\end{array}$} & \multicolumn{2}{|c|}{1933} & \multicolumn{2}{|c|}{1934} & \multicolumn{2}{|c|}{1935} \\
\hline & & $\% \mathrm{MgO}$ & $\begin{array}{l}\text { Av. of } \\
\text { treat- } \\
\text { ments }\end{array}$ & $\% \mathrm{MgO}$ & $\begin{array}{l}\text { Av. of } \\
\text { treat- } \\
\text { ments }\end{array}$ & $\% \mathrm{MgO}$ & $\begin{array}{l}\text { Av. of } \\
\text { treat- } \\
\text { ments }\end{array}$ \\
\hline \multirow[t]{4}{*}{ None $^{\mathrm{I}}$} & $D^{1}$ & 1.05 & & 1.09 & & 1.10 & \\
\hline & $\mathrm{S}^{3}$ & 1.35 & & 1.19 & & 1.07 & \\
\hline & $\mathrm{D}$ & .99 & 1.19 & 1.08 & 1.12 & 1.11 & 1.06 \\
\hline & $\mathrm{S}$ & 1.38 & & 1. 14 & & .95 & \\
\hline \multirow[t]{4}{*}{50} & D & 1.45 & & 1.48 & & 1.42 & \\
\hline & $\mathrm{S}$ & 2.01 & & 1.99 & & 1.51 & \\
\hline & $\mathrm{D}$ & 1.28 & 1. 68 & 1.56 & 1.79 & 1. 58 & 1.60 \\
\hline & $\mathrm{S}$ & 1.99 & & 2.14 & & 1.89 & \\
\hline \multirow[t]{4}{*}{75} & $\mathrm{D}$ & 1.59 & & 1.55 & & 1.53 & \\
\hline & $\mathrm{S}$ & 1.76 & & 2. . 0 & & 2.04 & \\
\hline & D & 1.61 & 1.77 & 1.82 & 1.99 & 1.67 & 1.97 \\
\hline & $\mathrm{S}$ & 2.17 & & 2.38 & & 2.62 & \\
\hline \multirow[t]{4}{*}{100} & D & 1.92 & & 2.17 & & 1.88 & \\
\hline & $\bar{S}$ & 2.46 & & 2.53 & & 2.45 & \\
\hline & D & 2.10 & 2.31 & 2.22 & 2.39 & 1.76 & 2.16 \\
\hline & $\mathrm{S}$ & 2.76 & & 2.63 & & 2.54 & \\
\hline \multirow[t]{4}{*}{125} & D & 2.30 & & 2.42 & & 1. 73 & \\
\hline & $\mathrm{S}$ & 3.15 & & 3.07 & & 2.65 & \\
\hline & D & 2.45 & 2.85 & 2.63 & 2.83 & 1.53 & 2.12 \\
\hline & $\mathrm{S}$ & 3.55 & & 3.22 & & 2.56 & \\
\hline
\end{tabular}

Here it is evident that with an annual application of 75 to 100 pounds of $\mathrm{MgO}$ per acre, producing a satisfactory ash, the leaf will contain about 2 per cent $\mathrm{MgO}$, which is in agreement with our previous findings.

\section{Magnesia Application Based on Microchemical Soil Tests}

On 10 plots which in 1930 received varying quantities of magnesian lime per acre (equivalent to 0, 100, 200, 400 and 600 pounds MgO), the

\footnotetext{
${ }^{1}$ These plots were limed in 1930 at the following rates, respectively: 0, 100, 200,400 and 600 pounds $\mathrm{MgO}$ per acre.

"D" and "S" = "darks" and "seconds" from duplicate plots.
} 
residual effects of these treatments were observed on the 1933 crop of tobacco.

In the spring of 1934, it was decided to make microchemical tests* of the soil on each individual plot of this series for estimation of available (replaceable) magnesia. With these figures in mind, we planned to add sufficient magnesian lime to make the total available $\mathrm{MgO}$ in all instances 100 pounds to the acre, including the amounts derived from the cottonseed meal and other fertilizer materials.

In 1935 the tests were repeated. The quantities of $\mathrm{MgO}$ in pounds per acre applied in each of the two-year periods are given below:

$\begin{array}{lccc} & 1930 & 1934 & 1935 \\ \text { A. A } & \text { No magnesia } & \text { (other than in organics) } \\ \text { B } & 100 & 45 & 100 \\ \mathrm{~B}_{1} & 100 & 65 & 300 \\ \mathrm{C} & 200 & 5 & 100 \\ \mathrm{C}_{1} & 200 & 45 & 200 \\ \mathrm{D} & 400 & 0 & 100 \\ \mathrm{D}_{1} & 400 & 5 & 100 \\ \mathrm{E} & 600 & 0 & 0 \\ \mathrm{E}_{1} & 600 & 5 & 0\end{array}$

To all plots the same general fertilizer was applied as reported above for the annual applications.

The three-year summary (Table 20) of results on the residual and equalization tests give further evidence that moderate quantities of magnesian lime affect neither yield nor grading.

Table 20. Yield and Grading Reconds of Magnesia Plots. Sumuary of Three Years' Results, 1933-1935

(Residual Series. MgO Equalized in 1934-35)

\begin{tabular}{|c|c|c|c|c|c|c|c|c|c|c|c|}
\hline \multicolumn{3}{|c|}{$\begin{array}{l}\text { Pounds } \mathrm{MgO} \text { per } \\
\text { acre per year }\end{array}$} & \multirow[t]{2}{*}{ Plot No. } & \multicolumn{4}{|c|}{ Yields per acre } & \multicolumn{4}{|c|}{ Grade Index } \\
\hline$\widetilde{1933}$ & $\mathrm{1}_{1931}$ & 1935 & & 1933 & 1934 & 1935 & Av. & 1933 & 1934 & 1935 & Av. \\
\hline 0 & 0 & 0 & $\begin{array}{l}\mathbf{A}^{* *} \\
\mathbf{A}_{1}\end{array}$ & 1698 & 1895 & 1959 & 1851 & .536 & .405 & .390 & .444 \\
\hline 0 & $\begin{array}{l}45 \\
65 \\
\end{array}$ & $\begin{array}{l}100 \\
300\end{array}$ & $\begin{array}{l}\mathrm{B} \\
\mathrm{B}_{1} \\
\end{array}$ & 1748 & 1825 & 1998 & 1857 & .538 & .419 & .378 & .445 \\
\hline 0 & $\begin{array}{r}5 \\
45 \\
\end{array}$ & $\begin{array}{l}100 \\
200 \\
\end{array}$ & $\begin{array}{l}\mathrm{C} \\
\mathrm{C}_{1}\end{array}$ & 1658 & 1748 & 1848 & 1751 & .543 & .422 & .358 & .441 \\
\hline 0 & $\begin{array}{l}0 \\
5\end{array}$ & $\begin{array}{l}100 \\
100\end{array}$ & $\begin{array}{l}\mathrm{D} \\
\mathrm{D}_{1}\end{array}$ & 1626 & 1798 & 1870 & 1765 & .562 & .424 & .379 & .455 \\
\hline 0 & $\begin{array}{l}0 \\
0\end{array}$ & 0 & $\begin{array}{l}\mathbf{E} \\
\mathbf{E}_{1}\end{array}$ & 1850 & 1789 & 2070 & 1903 & .538 & .451 & .380 & .456 \\
\hline
\end{tabular}

Chemical Analyses. In the same manner as reported above, samples of tobacco were analyzed for their content of magnesia. Results from these analyses are given in Table 21.

* Morgan, M. F. Microchemical Soil Tests. Conn. Agr. Exp. Sta. Bul. 333. 1932.

** Listed in Station records as 19, L9-1, L10, L10-1, L11, L11-1, L12, L12-1, L13, L13-1. 
Since it is desirable to obtain about 2 per cent $\mathrm{MgO}$ in the ash, the results indicate that the microchemical soil tests can safely be relied on when there is already a relatively high content of soil magnesia. In attempting to estimate the need of magnesia application through the use of the microchemical soil test (more recently called Universal Soil Testing System for Connecticut Valley), proportionately more magnesia should be applied, the less magnesia the soil contains, in order to attain desirable results. In other words, if it is decided to raise the magnesia content of a soil containing about 25 pounds per acre, more than 75 pounds should be added to form some 100 pounds available (replaceable) magnesia. A lower content of magnesia in the soil is often accompanied by a higher acidity (lower $\mathrm{pH}$ value) and it is possible that when magnesia is applied in the form of magnesian lime, a part of it in the neutralizing action of the lime becomes fixed and unavailable for plants. Further investigations are needed to warrant recommendations on magnesia applications based on soil tests.

Table 21. Content of MGO in Tobacco from "Residual" and "Equalization" Plots. Crops of 1933, 1934 and 1935. Air Dry Basis

\begin{tabular}{|c|c|c|c|c|c|c|c|}
\hline & \multirow[b]{2}{*}{$\begin{array}{l}\text { Grade } \\
\text { of } \\
\text { tobacco }\end{array}$} & \multicolumn{2}{|c|}{1933} & \multicolumn{2}{|c|}{1934} & \multicolumn{2}{|c|}{1935} \\
\hline & & $\% \mathrm{MgO}$ & $\begin{array}{l}\text { Av. of } \\
\text { treat- } \\
\text { ments }\end{array}$ & $\% \mathbf{M g O}$ & $\begin{array}{l}\text { Av. of } \\
\text { treat- } \\
\text { ments }\end{array}$ & $\% \mathrm{MgO}$ & $\begin{array}{l}\text { Av. of } \\
\text { treat- } \\
\text { ments }\end{array}$ \\
\hline \multirow{4}{*}{$\begin{array}{c}\text { Control } \\
\text { A } A_{1}\end{array}$} & $\mathrm{D}$ & 1.13 & \multirow{4}{*}{1.26} & 1.06 & & 94 & \multirow{4}{*}{.93} \\
\hline & $\mathrm{S}$ & 1.37 & & 1.18 & & 1.17 & \\
\hline & $\mathrm{D}$ & 1. 14 & & 1.03 & 1.14 & .71 & \\
\hline & $\mathrm{S}$ & 1.41 & & 1.29 & & .88 & \\
\hline \multirow{4}{*}{ B $B_{1}$} & D & 1.31 & \multirow{4}{*}{1.51} & 1.37 & & 1. 33 & \multirow{4}{*}{1.87} \\
\hline & $\mathrm{S}$ & 1.53 & & 165 & & 1.55 & \\
\hline & D & 1. 38 & & 1.79 & 1.76 & 1.91 & \\
\hline & $\mathrm{S}$ & 1.83 & & 2.23 & & 2.70 & \\
\hline \multirow[t]{4}{*}{$\mathrm{C} \mathrm{C}_{1}$} & D & 1.61 & \multirow{4}{*}{1.84} & 1.57 & & 1.27 & \multirow{4}{*}{1.82} \\
\hline & $\mathrm{S}$ & 2.04 & & 1.86 & & 1.76 & \\
\hline & D & 1.46 & & 1.69 & 1.88 & 1.89 & \\
\hline & $\mathrm{S}$ & 2.24 & & 2.42 & & 2.37 & \\
\hline \multirow{4}{*}{ D $D_{1}$} & D & 1.66 & \multirow{4}{*}{1.96} & 1.82 & & 1.96 & \multirow{4}{*}{1.96} \\
\hline & $\mathrm{S}$ & 2.04 & & 2.27 & & 2.03 & \\
\hline & D & 1.64 & & 1.64 & 2.01 & 1.77 & \\
\hline & $\mathrm{S}$ & 2.50 & & 2.30 & & 2.08 & \\
\hline \multirow[t]{4}{*}{$\mathbf{E} \mathbf{E}_{1}$} & D & 2.15 & \multirow{4}{*}{2.41} & 2.19 & \multirow{4}{*}{2.19} & 1.30 & \multirow{4}{*}{1.73} \\
\hline & $\mathrm{S}$ & 3.29 & & 2.68 & & 2.08 & \\
\hline & D & 1.77 & & 1.72 & & 1.58 & \\
\hline & $\mathrm{S}$ & 2.44 & & 2.19 & & 1.94 & \\
\hline
\end{tabular}

\section{Anhydrous Magnesium Sulfate (Kieserite, EMJEO) as a Source of Magnesia}

Anhydrous (without water) magnesium sulfate under the commercial names of Kieserite and EMJEO recently have been put on the market and are offered as substitutes for, or a supplement to, magnesian lime. The materials contain about 30 per cent $\mathrm{MgO}$ and being soluble salts might be expected to be more readily available. 
With the purpose of testing the availability of this magnesium salt in comparison with magnesian lime, an experiment was made in 1934 with one plot receiving the magnesium sulfate, another the magnesian lime (hydrated) and a control plot with no special carrier of magnesia. The magnesia was applied at a rate of 100 pounds $\mathrm{MgO}$ to the acre together with a complete fertilizer mixture which was identical for all three plots.

The yield and grading is found in the summary below:

$\begin{array}{lcc}\text { Treatment } & \text { Yield, lbs. per acre } & \text { Grade index } \\ \text { Control } & 1810 & .367 \\ \text { Magnesian lime } & 1753 & .314 \\ \text { Kieserite } & 1863 & .353\end{array}$

There seems to be a slight falling off in yield and grading for the magnesian lime, an unexpected development in consideration of our previous experience with this source of magnesia. The result with Kieserite was about equal to that with the control; thus with respect to yield and grading the use of Kieserite should prove satisfactory.

Chemical analysis. Samples of "darks" and "seconds" from the three plots mentioned above were analyzed with respect to their content of magnesia. The results computed on the basis of air-dried leaf are given in Table 22.

Table 22. Content of MgO in Tobacco leaves from Kieserite Test. Air Dry Basis

\begin{tabular}{|c|c|c|c|}
\hline \multirow[t]{2}{*}{ Treatment } & \multicolumn{3}{|c|}{ Per cent $11 \mathrm{gO}$} \\
\hline & Darks & Seconds & $\overrightarrow{A v .}$ \\
\hline Control & 1.026 & 1.023 & 1.02 \\
\hline Magnesian lime & 1.427 & 1.717 & 1.58 \\
\hline Kieserite & 1.645 & 1.943 & 1.80 \\
\hline
\end{tabular}

Results from these analyses indicate that magnesia supplied in the form of sulfate is somewhat more readily absorbed by the plants than magnesia in the form of magnesian lime. In this test the sulfate proved to be about 10 to 14 per cent more efficient than the lime: hence in using this material one should be guided by this apparent difference in availability of the magnesia in these two materials.

This magnesium sulfate (Kieserite, EMJEO), being a nearly neutral salt, should not affect the soil reaction either way, and may be recommended for tobacco on soils having a desirable soil reaction $(\mathrm{pH})$ and a satisfactory calcium content, but in need of considerable magnesia.

\section{Summary and Conclusion}

The amount of magnesia in the fertilizer did not greatly affect yield or grading of the crop but had a decided influence on the combustion of the leaf. The color of the ash of a cigar is an index of its chemical composition. Thus a relative excess of potassium may produce a dark ash, while increasing amounts of magnesium will brighten the ash proportionately. An excess of manganese in the ash has been found to give it an undesirable color known to the tobacco trade as "muddy" or "brick color." At a minimum of less than 04 of 1 per cent manganese $\left(\mathrm{Mn}_{3} \mathrm{O}_{4}\right)$ in the leaf, the discoloration does not appear. 
In order to produce a proper combustion of the leaf, an annual application of 75 to 100 pounds magnesia in the form of magnesian lime has been found preferable to larger applications at intervals of several years. Chemical analyses have revealed the presence of about 2 per cent $\mathrm{MgO}$ in the leaf at the above rate of application. Smoke tests have corroborated these findings.

An attempt was made to determine the need of magnesia applications through the use of microchemical soil tests. The results are not conclusive, but indicate the possibilities of the method, which, however, requires further investigation.

An anhydrous magnesium sulfate (about 30 per cent $\mathrm{MgO}$ ), sold under the commercial name of Kieserile or EMJEO has been tested as a source of magnesia. It was found that this material is 10 to 14 per cent more efficient than magnesian lime. It may be used on land in greater need of magnesia where the soil reaction might be adversely disturbed when larger guantities of magnesia were to be applied.

\section{EXPERIMENTS TO DETERMINE THE BEST TIME}

\section{TO HARVEST HAVANA SEED TOBACCO}

When the first blossoms open, it is time to break the tops off the tobacco plants. Most growers agree on this point but there is considerable diversity of opinion and practice as to how many days should elapse between topping and harvesting. Naturally the period varies with the character of the sweather.

All growers recognize the signs of leaf ripening, such as yellow mottling, down curving of the margins, and the thickening of the blades, and they try to harvest when they think the tobacco is ripe. But the ripening process extends over a considerable period of time. It begins with the lower leaves and progresses upward for a week or longer before the top leaves show the proper symptoms. Some growers cut the tobacco when the center leaves have reached this stage; others prefer to have the top leaves quite ripe. In the latter case, the lower leaves become overripe and are spoiled, or at least of inferior quality. If the tobacco is harvested too soon after topping, the leaves are green and thin and it is a common belief that they do not burn so well and are inferior in taste and aroma.

There are no recorded experiments in which an attempt has been made to determine the time at which Havana Seed or Broadleaf tobacco should be harvested in order to secure the best quality and the maximum yield. Therefore, such an investigation was plamned, begimning in 1935, to be carried out through a series of years in order to minimize the effects of seasonal variation. Some interesting results of the first year's experiment are presented at this time.

From a field that was quite uniform in appearance and growth, three plots, each of three rows and containing 400 plants, were used. All plants were topped on July 22. After removing the border rows, the first plot was harvested one week after topping, the second plot two weeks after topping, and the third plot three weeks after topping. All plants were hung on the same tier in the curing shed. The excessive rains of June and July caused a shortage of nitrates in the soil and many yellow, starved 
leaves were found at sorting time. This starvation complicated the data and must be kept in mind in interpreting the year's results. The tobacco harvested the first week after topping was obviously too green, according to our standards, while that harvested three weeks after topping was completely ripe, even to the top leaves, possibly overripe. It was observed in the curing shed that the plants harvested last cured in the shortest time, while those harvested one week after topping cured very slowly and there were still green leaves long after the others had cured. Thus it was demonstrated strikingly that the maturity of the leaves at harvest has considerable influence on the speed of the cure.

On the sorting bench, a distinct difference was also evident. Tobacco harvested one week after topping was thinner, somewhat shorter, and all grades had an olive green cast. It appeared silky and of excellent quality otherwise. From the later harvestings the leaves were distinctly heavier, coarser with more prominent veins, longer, and the green cast was gone. There was a higher proportion of starved yellow leaves, classed as "brokes", especially among those harvested three weeks after topping. Thus the grade index was considerably reduced. Presumably this fault would not be so damaging during a season of less rainfall.

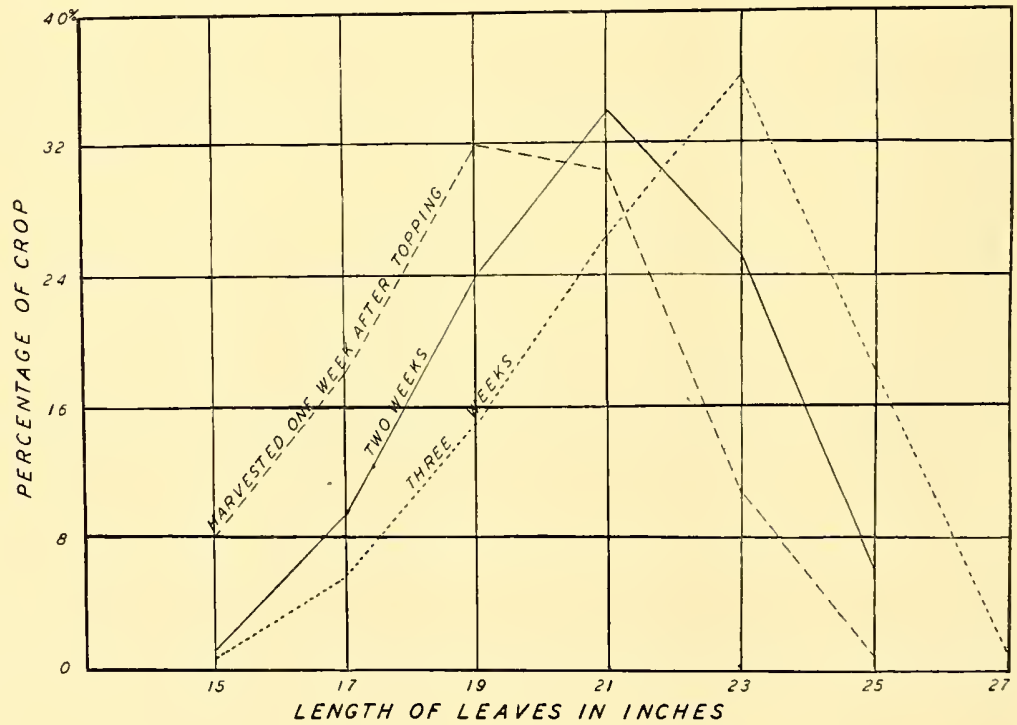

Figure 133. Leaf length as affected by time of harvesting.

The yield and grading records taken at the time of sorting are presented in Table 23. The figures show that there was a steady increase in weight after topping up to at least three weeks. In order to see how much of this might be due to increase in the actual size of leaves, they were sized (intervals of 2 inches) and the percentage of the crop in each length was computed. The results, presented graphically in Figure 133, show that the actual leaf area increases continuously after topping. 
In order to see whether there was an increase in the absorption of salts from the soil, and whether a part of the increase in weight was due to accumulation of mineral salts, analyses were made of samples from two grades of each of the lots harvested at different periods after topping.

Table 23. Experiments on Time of Harvesting. Sonting and Yield Reconds FOR 1935

\begin{tabular}{c|c|c|c|c|c|c|c|c|c|c|c}
\hline \hline \multicolumn{1}{c|}{ Time of harvesting } & $\begin{array}{c}\text { Yield in pounds } \\
\text { per acre }\end{array}$ & L & M & LS & SS & LD & DS & F & B & $\begin{array}{c}\text { Grade } \\
\text { index }\end{array}$ \\
\hline $\begin{array}{c}\text { One week after } \\
\text { topping (July 29) }\end{array}$ & 1518 & - & 1 & 24 & 9 & 39 & 13 & 10 & 4 & .334 \\
\hline $\begin{array}{c}\text { Two weeks after } \\
\text { topping (Aug. 5) }\end{array}$ & 1856 & - & 1 & 30 & 4 & 43 & 6 & 8 & 8 & .355 \\
\hline $\begin{array}{c}\text { Three weeks after } \\
\text { topping (Aug. 12) }\end{array}$ & 2003 & - & & 19 & 1 & 45 & 4 & 8 & 23 & .291 \\
\hline \hline
\end{tabular}

The results presented in Table 24 show that there has been no actual increase or accumulation of salts as expressed in percentage of the dry weight of the leaves. In other words, the salt intake has merely kept pace with the increase in size and weight of the leaves so that the more mature leaves do not contain proportionately any more mineral elements than the green leaves.

Table 24. Analyses of Leaves Harvested at Different Intervals After Topping

\begin{tabular}{|c|c|c|c|c|c|}
\hline \multirow{2}{*}{$\begin{array}{l}\text { Interval after } \\
\text { topping }\end{array}$} & \multirow{2}{*}{ Grade } & \multicolumn{4}{|c|}{ Percentage of } \\
\hline & & Total ash & Potash $\left(\mathrm{K}_{2} \mathrm{O}\right)$ & Lime $(\mathrm{CaO})$ & Magnesia $(\mathrm{MgO})$ \\
\hline 1 week & $\begin{array}{l}\mathrm{D} \\
\mathrm{S}\end{array}$ & $\begin{array}{l}18.24 \\
20.53\end{array}$ & $\begin{array}{l}5.70 \\
5.92\end{array}$ & $\begin{array}{l}5.46 \\
5.68\end{array}$ & $\begin{array}{l}1.37 \\
1.54\end{array}$ \\
\hline 2 weeks & $\stackrel{\mathrm{D}}{\mathrm{S}}$ & $\begin{array}{l}16.67 \\
19.54\end{array}$ & $\begin{array}{l}5.16 \\
5.20\end{array}$ & $\begin{array}{l}4.23 \\
6.42\end{array}$ & $\begin{array}{l}1.09 \\
1.41\end{array}$ \\
\hline 3 weeks & $\begin{array}{l}\mathrm{D} \\
\mathrm{S}\end{array}$ & $\begin{array}{l}15.98 \\
19.65\end{array}$ & $\begin{array}{l}4.65 \\
5.21\end{array}$ & $\begin{array}{l}4.93 \\
6.06\end{array}$ & $\begin{array}{l}1.22 \\
1.47\end{array}$ \\
\hline
\end{tabular}

TOBACCO INSECTS IN 1935

\author{
Donald S. Lacroix
}

\title{
Prevalence of Insect Species 1935
}

The spring of 1935 was cold, and both plant and insect life were from ten days to two weeks later in development than in seasons past. This was quite noticeable in the case of the potato flea beetle ${ }^{i}$, the overwintering adults of which did not appear in tobacco seedbeds until after the

\footnotetext{
${ }^{1}$ Epitric cucumeris Harris.
} 
middle of May. There was a moderate to heavy infestation of this insect throughout the Valley on young tobacco plants in the field in early June.

During the last week in July and the first week in August, a heavy infestation of the potato flea beetle developed on Broadleaf tobacco in East Windsor, South Windsor, and Ellington and caused serious injury. Only by thorough and constant dusting was the pest held in check on Shade-grown tobacco.

Wireworms ${ }^{1}$ were as injurious as usual, taking the tobacco-growing area as a whole. In some isolated instances they worked later than they did last season.

Cutworms of various species were very persistent in 1935. The black cutworm $^{2}$ injured Broadleaf plantations around Windsorville during the last part of June, and on plantations not treated with poisoned bran bait, infested about one-third of the plants.

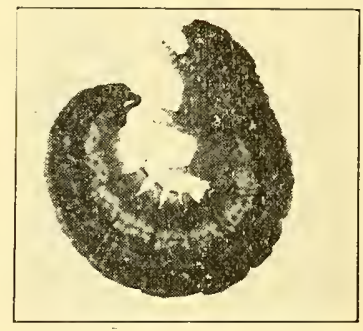

Figure: 134. Larva of dark-sided cutworm.

(One and one-half times enlarged.)

Another species, the dark-sided cutworm ${ }^{3}$, discovered in seedbeds in Windsor the third week in May. was also taken in late June and early July in the field.

The spotted cutworm ${ }^{4}$ was observed the third week in July on the outside rows of Broadleaf tobacco at Warehouse Point. A field of alfalfa, adjoining the tobacco, had just been cut, and the cutworms were migrating into the tobacco in large numbers.

The well-marked cutworm ${ }^{5}$ was not seen on tobacco this year.

A few specimens of the common stalk borer $^{6}$ were brought in from East Hartford on Shade-grown tohacco in mid-July.

The tobacco budworm? was far more injurious to tobacco on the Experiment Station farm at Windsor than it had been in the past. Unlike some of the other pests in 1935, there was no delay in its seasonal appearance as the first brood of larvae was active from early to late July and the moths emerged early in August. Injury from this pest was foumd in East Granby, West Suffield, East Windsor, South Windsor and Manchester.

The tobacco thrips ${ }^{8}$ caused more injury to Shade-grown tobacco during 1935 than it did in 1934, but was not so serious as it was during the dry

Pheletes ectypus Say.

Agrotis ypsilon Rotl.

Euxoa messoria Harris.

4 Agrolis c-rigrum linn.

Agroits unicolor Walker.

6 Papaipena nitela Guen.

7 Heliothis virescens Fabr.

${ }^{8}$ Frankliniella fusca Hinds. 
season of 1933. This species was taken in small numbers on Havana Seed tobacco and Broadleaf tobacco throughout the Valley.

Grasshoppers were normally abundant. Several cases of injury by the redlegged grasshopper' to Shade-grown tobacco came to our altention. In each case the land had been idle for a year or two before tobacco was planted or had been in hay. In West Suffield the Carolina grasshopper", was more abundant on Havana Seed tobacco than any other species.

Hornworms of hoth species ${ }^{3}$ were normally abundant in and around Windsor and about a week later than usual in first appearing. Throughout the Broadleaf plantations of East Windsor, South Windsor, and Ellington, they were not so numerous.

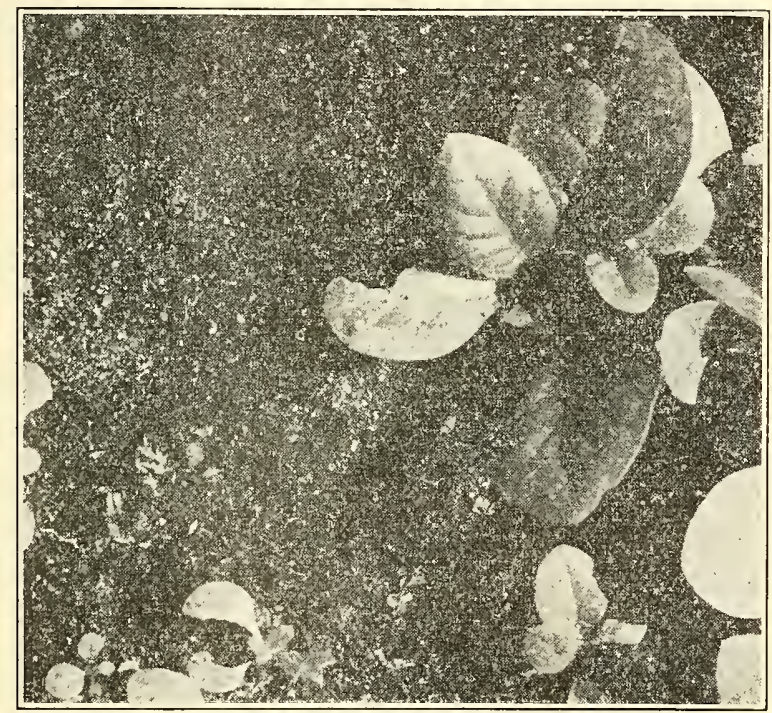

Figure 135. Dark-sided cutworm injury to plants in seedbed.

There was practically no injury to tobacco from the tarnished plant bug ${ }^{4}$.

The spined stink bug ${ }^{5}$ caused little trouble this season.

\section{Insect Control Experiments}

Tobacco budworm. ${ }^{6}$ The increase in population of the Tobacco budworm on the Experiment Station farm at Windsor necessitated prompt control measures. The recommended poisoned corn meal bait used in the South was applied. This bait was prepared by mixing 25 pounds of corn meal with one pound of arsenate of lead. A "pinch" (about half

${ }^{1}$ Melanoplus femur-rubrum De G.

2 Dissosteira carolina Linn.

3 Phlegethontius quinquemaculata Haw., and P. sexla Johan.

4 Lygus pratensis Linn.

"Enschistus variolarius Beauv.

- Heliolhis virescens Fabr. 
a teaspoonful) of the mixture was dropped in the bud of each of 25 infested plants (July 18, 1935). Twenty-four hours later these were examined and compared with 25 untreated plants. Dead worms were found on 23 poisoned plants and none on two. Of those untreated, 21 had live worms and 4 had none. This insect is not gregarious; only one worm is found on a plant in most cases.

Potato flea beetle.' Recent events have led agriculturalists away from the use of insecticides poisonous to man. This is particularly true in the case of plants grown for human consumption.

Barium fluosilicate has proven most satisfactory as a poison for the potato flea beetle on tobacco but there appears to be some question as to its effect upon human beings. Comparatively large quantities must be ingested by a person to cause any trouble, and the amounts used in dusting tobac ${ }^{-} \mathrm{o}$ are very small.

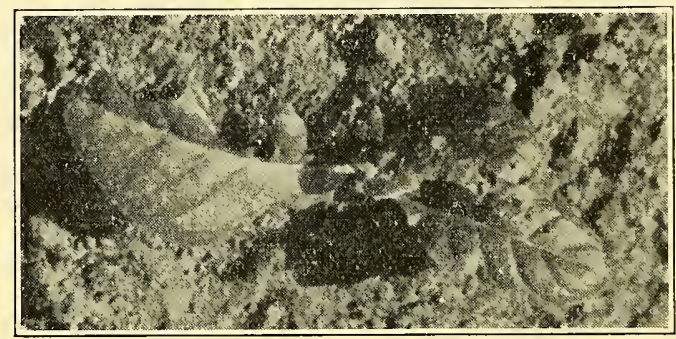

Figure 136. Dark-sided cutworm injury to young plant in field.

However, tests have been made with pyrethrum and derris compounds during the last few years, and in every case their toxicity to flea beetles has been pronounced. Unfortunately their insecticidal quality is not lasting and repeated dusting is necessary. In 1933 and 1934 "Cubor" (.5 per cent rotenone) and pyrethrum dusts were used successfully. In 1935 "Cubor" (.75 per cent rotenone) dust was used on several plantations with satisfactory results.

Another dust containing rotenone and known as "Ku-Ba-Tox" was tried on Shade and Havana Seed tobaccos during 1935. At full strength this material killed flea beetles rapidly and retained its toxicity for three or four days. When diluted with equal parts of tobacco dust, it gave equally good control. When mixed with equal parts of "Dutox," immediate control of the flea beetle resulted and the "Dutox" retained its killing action, keeping the beetle population down for more than a week. Table 25 indicates in actual figures just how the materials worked out.

No injury to the tohacco foliage was apparent on any of the treated plots.

The figures below indicate that the materials used were equally effective in control of the beetle, but the tests ended prematurely as the insects

${ }^{1}$ Epitrix cucumer is Harris.

${ }^{2}$ Barium fuosilicate 
disappeared from the whole Station plantation (even from untreated plots) while these experiments were in progress.

Flea beetle resistant tobacco. Several different types of Havana Seed tobacco are grown at the Experiment Station in the strain studies. It was observed late in July that certain strains were much more seriously

Table 25. Insecticide Tests on the Potato Flea Beetle (Havana Seed and Broadelaf Tobacco)

\begin{tabular}{|c|c|c|c|}
\hline \multirow[b]{2}{*}{ Material used } & \multicolumn{3}{|c|}{ Number of Flea Beetles per $\mathbf{2 5}$ plants } \\
\hline & $\begin{array}{l}\text { At time of } \\
\text { treatment }\end{array}$ & $\begin{array}{l}24 \text { hours after } \\
\text { treatment }\end{array}$ & $\begin{array}{l}48 \text { hours after } \\
\text { treatment }\end{array}$ \\
\hline $\begin{array}{l}\text { "Ku-Ba-Tox" and } \\
\text { tobacco dust, } \\
\text { equal parts, } \\
\text { "Ku-Ba-Tox" and }\end{array}$ & 178 & 31 & 26 \\
\hline $\begin{array}{l}\text { "Du-ba-1 ox and } \\
\text { putox", equal }\end{array}$ & 257 & 30 & 18 \\
\hline $\begin{array}{l}\text { "Dutox" and tobacco } \\
\text { dust, } 1: 3\end{array}$ & 204 & 32 & 21 \\
\hline Check & 193 & 236 & 283 \\
\hline
\end{tabular}

infested with the potato flea beetle than others. A series of population counts showed that the Brown strain (No. 8) was much more seriously injured than the No. 211 strain. The following table (Table 26) contains the figures resulting from these counts.

Table 26. Preference of the Potato Flea Beetle for Certain Toracco Strains

\begin{tabular}{lrc}
\hline \hline & Strain & $\begin{array}{c}\text { Number of beetles per } \\
25 \text { plants }\end{array}$ \\
\hline Adjacent rows & 212 & 178 \\
& 8 & 1,271 \\
\hline Adjacent rows & 211 & 257 \\
& 8 & 1,421 \\
\hline $\begin{array}{l}\text { (10 rows from nearest } \\
\text { No. 8 strain) }\end{array}$ & 211 & 40 \\
\hline \hline
\end{tabular}

Another observation made in connection with these studies indicated that the whole plantation was not so serionsly infested this year as in the past. All the Havana Seed tobacco at the Experiment Station (with the exception of the strain test plots) was No. 211 in 1935, and in previous years was the Brown strain. Then, too, the Broadleaf and Shade tobacco plots were well infested with flea beetles this year while the No. 211 strain was not. All these facts naturally bring up the question, "Is No. 211 Havana Seed tobacco distasteful to flea beetles?"

Tobacco thrips.' Many attempts have been made during the last few years to find a dust which would control the tobacco thrips, and in every

\footnotetext{
1 Frankliniella fusca Hinds.
} 
case the material used has been most unsatisfactory. Various pyrethrum and derris dusts have been compounded with carriers of all types and given thorough trials. On the other hand, sprays containing pyrethrum or derris have consistently given fair to good control.

During 1935 investigations were continued on control measures for thrips and the same results were obtained. Dusts proved of no value while sprays gave good results. "Ku-Ba-Tox" liquid spray and "Cubor" spray were promising in preliminary tests and were tried again on a larger scale. The following table shows how these materials worked under field conditions.

Table 27. Insecticide Tests on Tobacco Thrips Control (Shade Tobacco)

\begin{tabular}{|c|c|c|c|c|}
\hline \multirow{3}{*}{$\begin{array}{c}\text { Material applied } \\
\text { July } 29,1935\end{array}$} & \multicolumn{4}{|c|}{ Number of thrips on 25 leaves } \\
\hline & \multicolumn{2}{|c|}{24 hours later } & \multicolumn{2}{|c|}{48 hours later } \\
\hline & Dead & Alive & Dead & Alive \\
\hline $\begin{array}{l}\text { "Ku-Ba-Tox" and } \\
\text { water, 1:400 }\end{array}$ & 57. & 0 & 51 & 1 \\
\hline $\begin{array}{c}\text { "Cubor" and water, } \\
2 \text { lbs. to } 50 \text { gals. }\end{array}$ & 64 & 2 & 47 & 1 \\
\hline $\begin{array}{c}\text { "Loro" and water, } \\
\text { 1:600 with soap }\end{array}$ & 47 & 11 & 39 & 15 \\
\hline Check & 0 & 34 & 0 & 41 \\
\hline
\end{tabular}

"Ku-Ba-Tox" and "Cubor" sprays gave a very good kill but "Loro" was only fair. "Cubor," when used at the strength indicated, must be very carefully mixed and used in an absolutely clean sprayer or it will not all dissolve. This, of course, leaves an undesirable residue. None of the materials injured the leaf.

In view of these encouraging results, it seems most advisable to carry on further spray trials on a large scale to determine how often and at what times to apply them. In any case, it would be advisable to start spraying in late June when the plants are comparatively small and when the thrips first appear.

Wireworm investigations. Studies on the life history of the Eastern Field Wireworm ${ }^{1}$ have been continued in an effort to get all information possible on this pest. Particular attention has been devoted to the earlier stages in the life of this insect. Also a study of the development of infestations on a number of fields is being continued over a period of years to accumulate desirable ecological data. 
TOBACCO DISEASES IN 1935

\section{P. J. AndERson}

Diseases in general were somewhat more prevalent in 1935 than in the two previous years, probably due to the greater rainfall. Some of them were of sufficient importance to warrant special investigations described below. The occurrence and degree of severity of the rest are also recorded here. Most of our tobacco diseases are of minor importance, but some of the major ones should be more thoroughly investigated.

Black rootrot (Thielavia basicola) was found causing considerable damage in some of the seedbeds that had not been steamed. All the symptoms of yellow, stunted plants and rotted black roots were evident. If our beds were not sterilized so regularly, this disease would cause a great deal of trouble in Connecticut. Only once in 11 years has the writer found a serious case of black rootrot in steamed beds. As a rule, this disease does not often seriously affect Broadleaf in the field. In 1935, however, a two-acre area in a field in South Windsor produced such small stunted plants that the crop was hardly worth harvesting, while the rest of the field had tobacco of normal size. The roots of the dwarfed tobacco were seriously affected with rot. This part of the field was nearest the barn and heavy applications of manure had been applied, a treatment that is known to favor black rootrot.

Wildfire (Bacterium tabacum). After the serious epidemics of wildfire in the early "twenties", the disease became less and less prevalent here with each succeeding year. By 1934 it had practically disappeared from the Valley and there was hope that we would not be troubled with it again. No cases were found in the seedbeds in 1935, but in the late summer it appeared again in two or three localities and in some cases the fields were seriously affected at the time of harvesting. Reports from other sections of the United States suggest that after years of limited occurrence, wildfire may again be spreading. This year was marked by an unusually severe epidemic in Western Tennessee and Kentucky. It warns of the necessity of continuing the precautionary control methods that were developed and practiced by most of the growers when the disease was more prevalent.

Blackfire (Bacterium angulatum), a bacterial disease that is destructive in the more southern tobacco growing areas, was observed in Connecticut both on Broadleaf and Havana Seed this year in small amount. It is not a conspicuous or a serious disease here and does not seem to be spreading, although it can always be found somewhere. On one large field of Broadleaf this year, 10 per cent of the plants were affected. The spots are usually larger, less numerous and more definite in outline on Broadleaf than on Havana Seed. Usually only a part of the leaves on a plant are affected; in the field under consideration most of these were the bottom leaves. The dead spots vary in size from an eighth to a half inch or more in diameter. Sometimes the spots run together and kill large areas of the leaf. The most characteristic feature, as distinguished from other types of spots on tobacco, is the irregular, angular or jagged outlines. They also show wide variation in color, ranging from almost 
white through various shades of gray and brown to almost black. Figure 137 is a photograph of light-colored spots. On heavier leaves the spots may be more circular and less irregular in outline and the surface marked by somewhat concentric ridges. Leaves severely affected when young often become distorted. After curing, the spots remain white, conspicuous and rigid and do not soften easily during "casing." A severely affected leaf is worthless.

Microscopic examination of young spots showed no fungous mycelium in the tissues but great numbers of rod-shaped motile bacteria. These were isolated and the cultural characters found to agree with those recorded for Bacterium angulalum. Inoculation experiments in the greenhouse did not give conclusive results but prohably the conditions here were not favorable to infection.

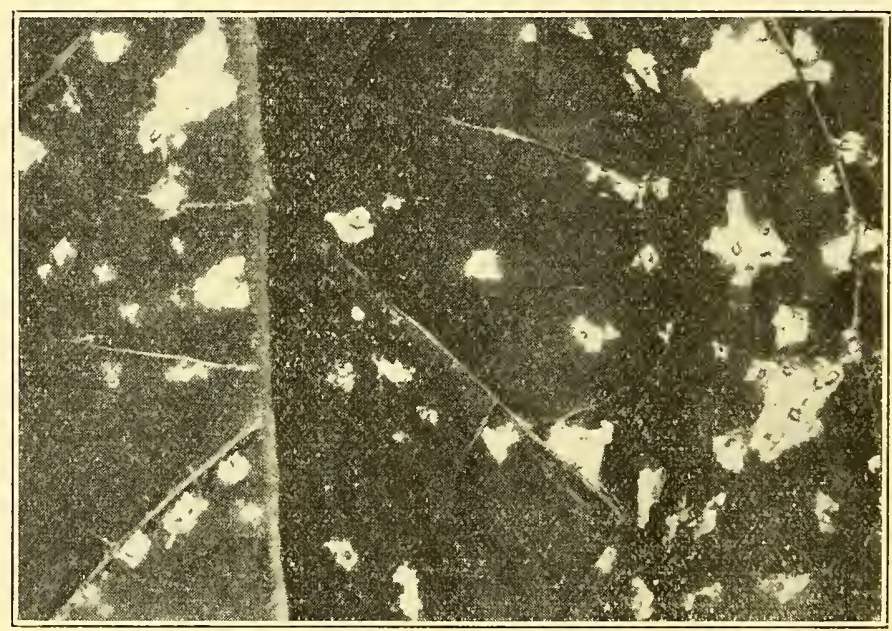

Figure 137. Angular spots on Broadleaf caused by the bacterial disease, Blackfire.

Mosaic (Calico) in the seedbeds. The method by which the virus of calico passes the winter and starts new infection each year is still a matter of considerable uncertainty. It is not improbable that there are several sources of the spring infection. There is pretty good evidence, however, that the seedbed is the principal avenue by which it arrives in the field. Yet one rarely sees a calico plant in the beds. This year, however, one Broadleaf grower brought to the Station some plants from his beds that showed plainly the symptoms of the disease. Fxamination of the beds revealed that plants were affected in a few small areas in some, and it was hoped that in the field the infection would be only local and could be removed. Although the plants were free from symptoms when they were set out, more and more of them developed the disease as they started to grow, until about 90 per cent were affected. All were removed in early July; the field was harrowed and set again with plants from a disease-free bed, and a good crop with only a small percentage 
of mosaic was harvested. It is obvious from this experience that it is not safe to set plants from a bed where there is any calico.

It has been demonstrated in Kentucky that a large percentage of the infection may be traced to the use of infected chewing and smoking tobacco by workmen. The virus gets on the hands and then is passed on to the plants that they touch in weeding, pulling, setting, etc. We have found many indications that at least a part of our bad infestations may start from the same source.

Some other diseases have been observed this year but were not sufficiently prevalent to warrant special investigation or note. Pythium Dampingoff and rootrot ( $P$. debaryanum) and the later bedrot (Rhizoctonia) were found in a few beds. Non-parasitic leafspots were present in the usual number.

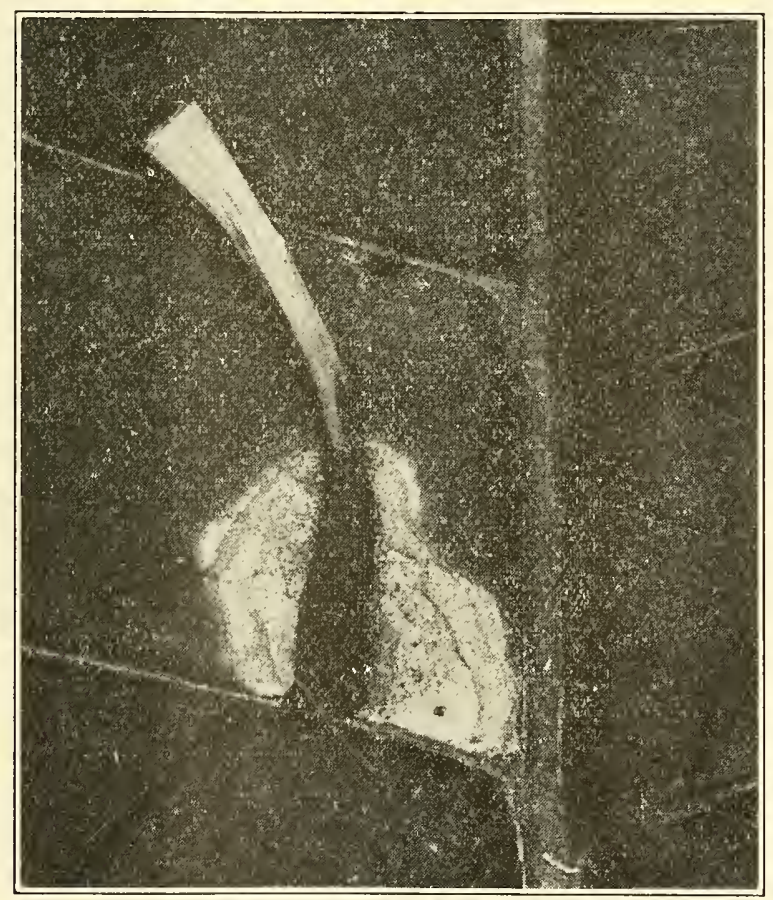

Figure 138. Dead-blossom leaf spot. Note the adherent, partly decayed blossom and the dead leaf area about it.

\section{Dead-blossom Leaf Spot}

During the latter part of August and in September, this spot became prevalent on Shade tobacco and was brought to our attention by several growers. It occurred particularly on the later primings and was undoubtedly favored by the wet weather that prevailed in most of the Valley during that period. The trouble is not new but has been known to Shade growers for many years. It is primarily a disease of this variety of 
tobacco-although occasionally seen on other kinds-because blossoms in great numbers are allowed to develop on Shade, while the tops and suckers are removed from the Sun-grown types. When the flowers are mature, the corollas, or pink-colored parts, drop, and many of them, especially in wet weather, adhere to the gummy leaves and decay. As shown in Figure 138, the dead spot spreads in all directions from the decaying blossom as a center. The higher humidity under the tent also favors the development of the spots on this type of tobacco.

Symptoms. Spots are irregular and wavy - not angular - in outline, up to an inch or more in diameter, with a quite definite margin. In color they vary from light tan to reddish brown, while some are faded to ashen gray. Spots are usually bordered more or less by an indefinite, narrow, light yellow halo that fuses outward gradually into the normal green of the leaf. The dead tissue is brittle and breaks out easily. The dead blossom remains tightly adherent to the center of the dead spot and usually becomes more or less blackened by masses of Alternaria spores. There may be one to a half-dozen spots on a leaf, thus rendering it worthless for wrapper or binder.

In the curing shed, where the leaf is in close contact with others on the same lath, the rot frequently spreads from one to the next until a dozen may be rotted. In the shed, under these conditions, the trouble has all the symptoms of pole rot.

Fungi associated with the spots. Fxamination of the dead blossoms shows the presence of spores of a considerable number of fungi. Alternaria tenuis is universally present and is the predominating fungus. Botrytis cinerea and Cladosporium herbarum are also very common. Sometimes there are also spores of Fusarium, Macrosporium, Monilia, Phoma, and other genera. Examination of the tissue beneath and adjacent to the dead blossoms shows spores and sporophores of Alternaria tenuis on the surface and Alternaria mycelium inside the tissues of the leaf. Other species are found more rarely on the adjacent leaf tissues. Frequently bacteria also are present in abundance inside the dead leaf. Isolations from the margins of the spots where no spores were found on the surface yielded almost invariably pure cultures of Alternaria tenuis.

In view of the considerable number of species of fungi and bacteria that are found in the decaying blossoms, it is difficult to decide which one, if any, is the primary parasite. Alternaria is the most umiversally present and its mycelium is constantly found inside the leaf tissue. As indicated by previous experiments of the writer, however, (Conn. Sta. Bul 367 , p. 134), the spores of this fungus sprayed on the leaves did not produce spots on the tobacco except very slightly on overripe, injured leaves. This indicates at the best a very weak degree of parasitism. It is possible, however, that in moist, warm weather, beneath a wet rotting corolla, the conditions might be such as to permit infection and a limited spread of Alternaria in the tissues. Or perhaps the virulence of Alternaria is "stepped up" by previous growth on the tobacco blossom to such a degree that it becomes truly parasitic on the green leaf. Possibly the combined influence of all the rot-producing organisms, in direct contact with a somewhat etiolated part of the leaf, might produce infection where 
any single one of them would fail. The presence of the dead blossom on the leaf is absolutely essential to the parasitism of whatever organism or organisms produce this type of spot. In the absence of blossoms the spots do not occur.

The spread of the rot in the curing shed from one leaf to adjacent leaves is readily understood in view of the known capacity of Alternaria to infect curing leaves under these conditions. This is no different from the usual pole rot except that the presence of the rotten corolla and adjacent dead tissue provides a very favorable nursery to serve as a starting point for spreading to the adjacent leaves under the moist conditions of a packed shed.

Previous observations. Leafspots caused by decaying blossoms have been noted and described by other observers both on other types of tohacco and on different species of plants. Thus in Germany, Gleisberg, (Gleisberg, W. Botrytis-Erkrankungen. Gartenflora 70: 13-18. 1921) found that similar dead brown spots were produced on Primula leaves and on about 25 other species of plants when blossoms of the locust tree (Robinia) fell on the leaves and rotted there during wet weather. He found that the blossoms become covered with a growth of the fungus, Botrytis cineria, which also spread to the leaf tissue. Ahliough pure culture inoculations were not made, he considered the evidence sufficient to warrant the conclusion that this fungus was the direct agent in the disease. During the same year, 1921, Pape (Pape, H. Beobachtungen bei Erkrankungen durch Botrytis. Gartenflora 70: 48-51. 1921) observed the same type of spot about blossoms which had fallen on tobacco leaves. His description and photographs which accompany his article show that he had under observation spots very similar to those which we find in Connecticut. He also found the spores of Botrytis cinerea on the surface and cultured this same fungus out of the affected leaf tissue. Therefore he concludes that it is the causal agent.

A more complete description of the trouble as it occurs on tobacco in Germany was later published by Boening ${ }^{1}$, who alludes to a popular belief of growers that the tobacco blossom contains a poison that has a corroding effect when in contact with the leaf. He finds the spots mostly on the middle and lower leaves of the plant, explaining this on the theory of better moisture relations for fungus growth on these leaves than on the upper leaves. Like the two writers just mentioned, he considers Botrytis cinerea the causal agent which is able to pass from the dead blossoms into the leaf tissues under the moist conditions which prevail under the adhering blossoms. He also noted that when hung up to cure, the infected leaves serve as foci from which the rot passes into the other curing leaves which are in contact, and thus many leaves may be ruined.

Control. No practical method of preventing the spots in the field under the usual cultural practices for Shade tobacco has been found. In the shed, the same methods must be used as for the control of pole rot. The surfaces of the leaves must be dried as soon as possible by proper

${ }^{1}$ Boening, Karl. Krankheiten des Tabaks. Eine durch herabgefallenen Blueten hervorgerufene Botrytisbiattfaule. Arbeiten aus der Bayer. Landesanstalt fur Pflanzenbau u. Pflanzenschutz, Heft 4: 18. 1928. 
firing and ventilation. (See Conn. Sta. Bul. 364 for more detailed description of firing).

\section{Pythium Stalk-rot of Transplants}

This disease was first brought to our attention about the first of June, when a Shade grower brought to the Station a basket full of plants which had died in the field a few days after transplanting. There had been frequent soaking rains during the transplanting season, and the constantly wet soil undoubtedly influenced the prevalence of the trouble. The

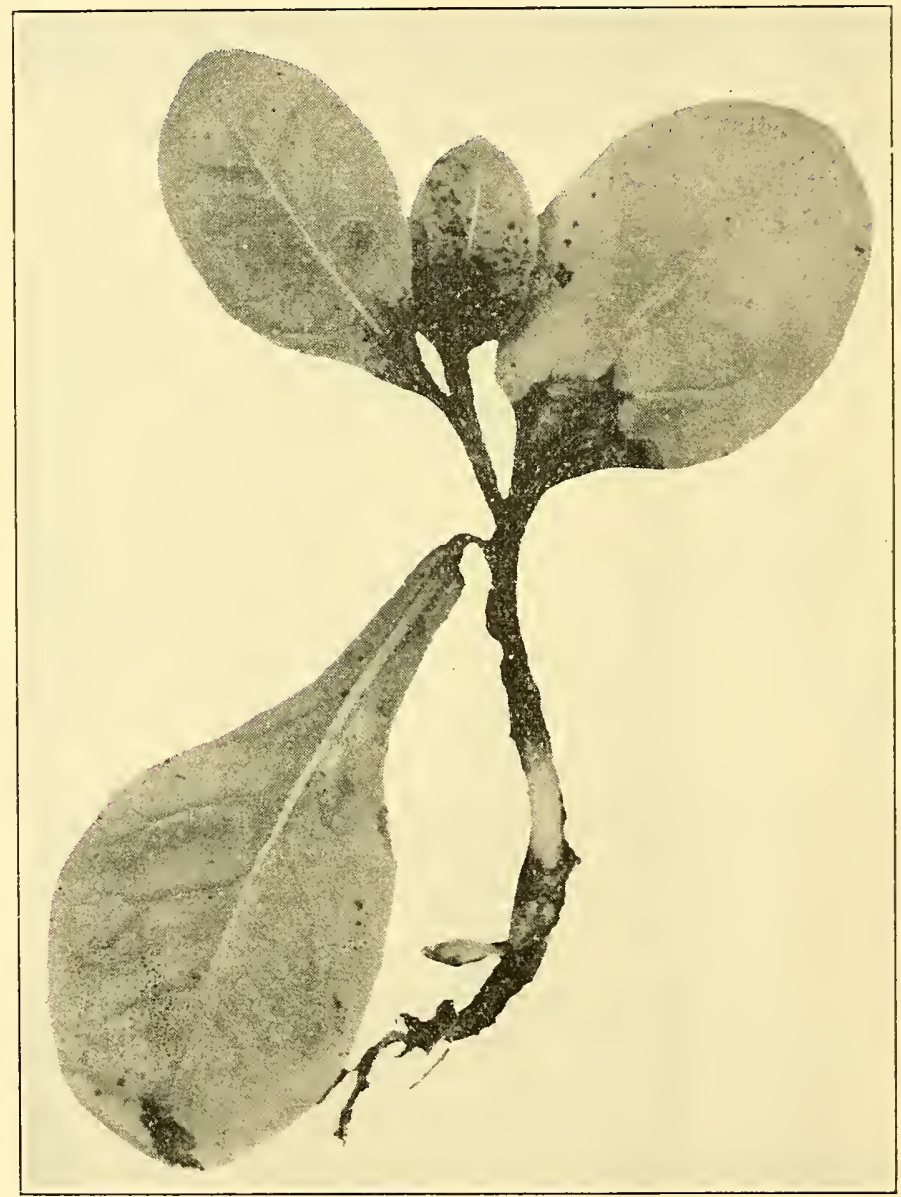

Figure 139. Pythium stalk-rot. Note the dead black stem and bases of leaves.

disease is probably not new here but no published description of it in America has come to our notice. In Sumatra, however, it has been known since about $1917^{1}$ under the name of "Stengelverbranding" (Stemburn).

\footnotetext{
${ }_{1}$ Meurs, A. Parasitic Stemburn of Deli Tohaceo. Phytopath. Zeitschr. 7: 169-185. 1934.
} 
Meurs found that it occurs both in the seedbeds (rare however) and in the fields shortly after transplanting. Although the trouble here has been observed only in the field, it is quite possible that it may be present also in the beds and has been confused with ordinary bed rot which it resembles. Examination of a number of fields showed that the disease was general throughout the Valley during 1935 and occasioned much extra labor in restocking.

Symptoms. This is a soft, watery, black (or at least very dark), mushy rot that completely disintegrates all the tissues of the stalk. It starts just at, or below, the ground level, but under favorable conditions quickly works upward even into the bases of the leaves (Figure 139) and causes the plant to fall over and completely collapse. The stalk is so rotted that it no longer holds together when the plant is pulled up. If the plants are kept over night in a moist chamber, they become covered with a thick white felt of mold.

Causal organism. Microscopic examination shows the tissues completely permeated with the mycelium and spores of a fungus, Pythium debaryanum. This fungus was easily isolated and grown in pure culture. In every respect it was identical with the fungus which was described and illustrated in our report for 1933 (Comn. Sta. Bul. 359: 336-354) as the cause of the early damping-off of tobacco seedlings in the beds. This fungus is present in most soils and it was not possible to determine whether it was carried on affected plants from the beds to the field or whether primary infection came from the field soil. Possibly both methods of infection play a part.

In Sumatra, four different species of Pythium have been found in the diseased plants and each, on re-inoculation, proved to be capable of producing the rot. One of these species was doubtfully called $P$. debaryanum.* The other three were studied by Meur (citation above) and found to be $P$. aphanidermatum (Eds) Fitz., P. myriolylum Dreschsler and $P$. deliense Meur. None of these last three species has been found in Connecticut but as far as symptoms are concerned, our disease appears to be identical with the Sumatra "stemburn."

Control. Prevalence of the disease is undoubtedly influenced by environmental conditions, being worse where moisture is greatest. We may therefore expect to find more or less of it any year when there are frequent rains during the selting season. Since the fungus is not new, there is no reason to fear that the disease will increase and become epidemic any more than it has in the past. Since there is a possibility that at least some of the infection starts in the beds, one obvious control measure would be to keep the bed as free as possible from disease by sterilizing the soil, by aeration and keeping the stand thin, and by avoiding too moist conditions. Succulent, tender, fast growing plants appear to be more subject to attack than those which are hardened. Meurs finds that the plants of the first pulling from the beds are more susceptible to attack than the later pullings. The use of well hardened and diseasefree plants should do much to keep this stalk-rot under control. It might

*Jochems, S. G. J. Stengelverbranding bii Deli-Tabak. Med. Deli Proefstation te MedanSumatra. Ser. 2, No. 49. pp. 35, 1927. 
prove profitable to discard the first pulling and use only plants from the later pullings.

\section{Studies on Pole Rot. I}

Of all the diseases that plague Connecticut Valley tobacco, pole rot probably presents the most baffling problem for the plant pathologist and for the grower and packer. Our knowledge of the causal agencies, influence of environmental and other factors, and of control is inadequate and confusing. Half of the farmers make no effort to use the recommended measures of control and many who use them are only partially successful. Some even believe that heating with charcoal--the commonly recommended measure - frequently aggravates rather than remedies the trouble. In view of the meagerness and uncertainties of our knowledge of pole rot, there is need of a thorough re-investigation of every phase of the trouble with the ultimate object of perfecting a method of control that will be easier to apply and more certain of success than any that we now have. This is not an easy task; perhaps we shall never be entirely successful. The chances of finding a better control method, however, will be more favorable after we have more fundamental information about the causal organisms, their mode of attack, response to environmental factors, etc. It was with the object of acquiring such fundamental information that the investigation here reported was started. The present discussion is a preliminary statement and will be followed by others as the work progresses.

Name. The rotting of tobacco during the time that it is hanging on the poles in the curing shed has been designated by a variety of names in different sections of this and foreign countries. Sweat, pole sweat, shed burn, house burn, pole burn, stem rot and pole rot are the most common names. "Stem rot" is the name applied only to the decay of the midribs.) The use of the term "burn" probably comes from the German name "Dachbrand" (literally "roof-burn"). Although the darkened dead appearance of the leaf produced by one of the types of this disease might by a stretch of the imagination be compared to the effect of burning, the term "burn" is certainly not descriptive of the various other symptoms. There is also an objection to the use of the term "sweat" because, in the trade, this term is used to designate the fermentation process, which has no relation to pole "sweat". The fact that sometimes drops of water collect on the leaf surfaces during damp weather, and may favor rot, probably explains the use of this term. The disease in all its various manifestations is nothing more than a "rot" of vegetable matter as this word is used and understood by English speaking people. This term is, therefore, used here to avoid hazy misconceptions on the part of the reader which the other names frequently connote. The term "pole rot", then, designates all forms of rot that affect the curing tobacco while hanging on the poles, and distinguishes it from other rots that may occur in the bundle, the case, or in the field.

Symptoms. Pole rot as a rule does not occur during the first stages of curing-that is, while the leaves are still green. Only occasionally and under very moist conditions, where the leaves have remained green for a long time in the shed, has the writer ever seen pole rot on a green 
leaf. In general the symptoms may be expected to appear on leaves which are in the yellow stage and just turning brown. The rot may appear on any of the leaves of the plant which are just passing through this critical stage, if continued moist weather conditions prevail at just that time. When the leaves wilt down around the stalk, the middle and lower ones form an overlapping sheath around the top of the stalk. As a result, the inner leaves remain under more moist conditions because of lack of air circulation and the greater quantity of water that is transpired from the green stalk and the crowded leaves. Such conditions are very favorable nests for pole rot to start and it is here, rather than on the outside leaves, that one usually finds the trouble first. Even where charcoal firing is resorted to, it is difficult to dry out the leaves in such places, and an insufficient firing is apt to make conditions more favorable to rot because the temperature is raised but the surfaces are not dried. Rarely, if ever, is a shed of stalk tobacco cured without an occasional such pocket where rot has started. The primed leaves of Shade tobacco are better distributed and there are no green stalks to furnish a continuous supply of moisture. Therefore pole rot is not so common in Shade tobacco as in stalk-cut tobacco. As a rule also, Shade tobacco is more carefully fired during the cure.

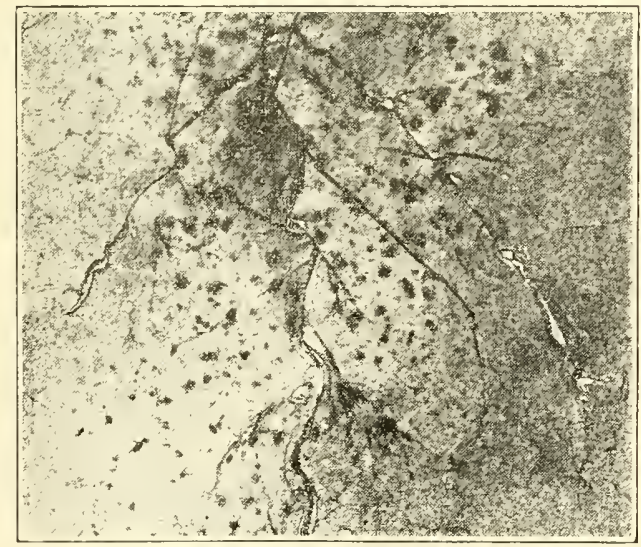

Figure 140. Pole rot. This spotting is the characteristic freckle rot symptom.

There is considerable and often confusing variation in the symptoms exhibited, depending on the part of the leaf attacked, severity of infection, time of infection and location of the leaf with respect to the other leaves. For convenience in discussion we may distinguish three types of pole rot: (1) freckle rot, (2) web rot and (3) vein rot. One, two or all of these may be present on the same leaf and they may intergrade into each other.

Freckle rot has usually been considered the initial stage of the disease, but this is not universally true since either of the other symptoms may 
appear first. Small dark specks, from pinhead size up to a quarter of an inch in diameter, appear on the blade of the leaf. They resemble in size, shape, distribution, and often in color, the freckles on a redheaded urchin's face. On light leaves they are deep, reddish brown, while on dark, heavy leaves they are almost black. When the leaf is held up to a strong light, the spots appear translucent. There is no fungous growth on the surface. Freckle rot is shown in Figure 140.

In web rot, large areas of the leaf blade are rotted and discolored and there is no indication of small local spots. The affected areas are usually several inches in diameter or may include the whole side of the leaf. In severe cases in the shed, the tissue is so disintegrated that the leaf tears apart between the hands when one tries to open it; that is, it no longer has any tenacity. The color, although varied, is always darker than that of the unaffected part of the leaf. Such areas, after curing, do not become soft and pliable when the rest of the tobacco comes "into case", but remain stiff and brittle and are easily broken during the sorting and packing. There is no elasticity and affected leaves are worthless for cigar wrappers and binders. Sometimes there seems to be a connection between the web-rot type and the freckle-rot type when a large lesion of web rot is bordered by freckles which gradually become less noticeable and disappear in the healthy tissue. One gets the impression that the web-rot type of lesion is produced by the enlargement and coalescence of the freckle spots. This theory, however, does not explain the many cases in which there are no freckles at all in comnection with many polerotted leaves. It is apparently possible to have web rot without an initial stage of freckle rot.

Vein rot (including stem rot) is the name applied where the rot involves principally the mid-vein or the large lateral veins. The veins, especially the nidribs, retain their moisture long after the leaf web has dried and therefore furnish very favorable substrata for growth of rot-producing organisms. They turn brown, become soft, and then are covered with a growth of white, gray or variously colored molds. The point at which the midrib is attached to the stalk is an especially favorable point of attack. Frequently the rot progresses to a point here where the slightest pull will make the leaf fall from the stalk, or sometimes it will even fall to the ground of its own weight. The rot also usually passes out somewhat into the adjacent web. When the leaf is stretched between the hands, the blade pulls away from the large midrib and the latter, being all rotted except the stringy fibers, frays out as the leaf is stretched. The same may be true for the large lateral veins just as for the midrib. Leaves thus affected are graded as "brokes" in the sorting, even though the blade may be perfectly sound.

Cause of pole rot. From the beginning of tobacco culture it was recognized that moisture bears an important relation to prevalence of pole rot, because the rot is always worse during wet curing seasons. Moisture, however, is not the direct cause, but is of importance only because it provides conditions in the shed which favor the growth of decay organisms that are the direct agents. Although it is now agreed by all investigators that organisms produce pole rot, there is considerable difference of opinion as to which of the various fungi and bacteria found in rotted tobacco are the primary agents in decay. There is the possibility 
that the organisms that cause the trouble in one section are not the same as those that operate in another tobacco section; or that the organisnis that produce one type of rot are not the same as those that produce another type. This uncertainty may be ascribed for the most part to the almost insurmountable difficulty of making pure culture inoculations on leaves, under natural, but at the same time, sterile conditions-the only method of proving definitely the causal relation of an organism to a disease.

Mueller-Thurgau ${ }^{1}$, in 1885, stated that pole rot is caused by fungi and warned against too high moisture in the air of the curing chamber since "thus the curing process is too long drawn out and fungi of different sorts settle on the leaves and have an unfavorable influence on the quality of the product. The dreaded "Dachbrand" is of this nature and I have regularly found on these leaves Pleospora-like fungi". Thus the first investigator to ascribe pole rot to fungi, believed it was associated with Pleospora (ascospore stage of Alternaria).

Sturgis $^{2}$, of the Connecticut Agricultural Fxperiment Station, in 1891 was apparently the first to make a serious attempt to find what organisms are responsible. He decided that the rot was due to the growth of bacteria but that a fungus (he mentions Cladosporium) first made it possible for the bacteria to gain access. To quote from him: "Pole burn is due primarily to the growth of a fungus upon the leaf which by disintegrating and partially destroying the tissue of the leaf gives access to a bacterial process of decay".

Two years later Behrens ${ }^{3}$ in Germany came to the conclusion as a result of his investigations that pole rot is always caused by one of two fungi, Sclerotinia Libertiana Fuck, or Botrytis cinerea which he considered the conidial stage of Sclerotinia Fuckeliana de R. Although he found species of Aspergillus, Penicilleum, Cladosporium and Alternaria present, he considered them as secondary saprophytes which had no relation to the rot. He found that the Sclerotinias usually occurred first on the midribs and only later passed to the leaf, an observation that indicates he was investigating a trouble that corresponds more nearly to the type we have called vein rot.

In 1893 Sturgis $^{4}$ states that stem rot is due to Botrytis longibrachiata (-Botryosporium pulchrum Cda., according to Clinton in Conn. Sta. Rpt. for 1903, p. 362). After referring to the work of Behrens, he reiterates his belief in the bacterial nature of the other types of pole rot: "We are, therefore, convinced that although the initiative in pole-burn may be taken by a Botrytis or some similar fungus, the preliminary growth of which may even be essential to the succeeding condition of decay, the latter is largely bacterial in its nature.'

Six years later Sturgis ${ }^{5}$ made a further study of pole rot in the initial stages, and after making cultures and microscopic examination, stated:

1 Mueller-Thurgau, Herman. Ueher das Verhalten von Staerke und Zucker in reifenden und trochennden Tabaksblat tern. Landw. Jahrb. 14: 485-515. 1885.

${ }^{2}$ Preliminary report on the so-called pole hurn of tohaceo. Conn. Agr. Exp. Sta. Rpt. 15, 168186. 1891 .

${ }^{3}$ Behrens, J. Trockene und nasse Faule des Tabaks, "der Dachbrand." Zeitschr. f. Pflansenkr. 3: $82-90.1893$.

"Sturgis, W. C. Further notes on the eause of "pole sweat" and "stem rot" of tohacco. Conn. Agr. Exp. Sta. Rpt. 17 (1893): 81-85. 1891.

${ }^{5}$ Sturgis, W. C. Further notes on the pole-burn of tobacco. Conn. Agr. Exp. Sta. Rpt. 23 (1899): 255-269. 1900. 
"I can only conclude from these cultures that as far as regards the organisms associated with the earliest stages of pole burn--this species of Alternaria is the only one which occurs in any abundance and that it occurs only on the surface of the leaf, not in the internal tissues". "The fungus which was associated with the trouble [referring to his previous report] was unquestionably a species of Cladosporium; in the present instance unquestionably a species of Alternaria. These statements are not contradictory. They merely indicate that under certain atmospheric conditions, any saprophytic fungus which may be present in the curing barn may attack the dead tissues of the leaves and start in them a process of disintegration which will almost surely be followed by true bacterial decay."

In Wisconsin, Johnson isolated fourteen different forms of fungi from decaying tobacco, only three or four of which were of general occurrence under field conditions. The most common was Fusarium, but frequently he found Trichothecium roseum and Penicillium brevicanle and occasionally, Alternaria and Botrytis. He states: "No particular organism can be universally ascribed as the cause of this disease. Noreover, it is to be expected that dead or dying tissues, such as occur in curing tobacco, will become substrata for various saprophytic organisms when conditions favorable for their development occur. Furthermore, it seems most reasonable to suppose that such organisms as sometimes exhibit considerable parasitic action should be the first, and the ones most likely to produce the decay of curing tobacco. For this reason we may expect that the purely saprophytic fungi should occur more rarely, if at all. The occurrence of species of Fusarium, Botrytis, Sclerotinia and Alternaria seems to indicate that these organisms exhibit some parasitism upon the slowly dying leaves.

"These observations indicate that the causal organisms of shed burn and stem rot vary in different sections of the country, and that it is in all probability a matter of the organisms with which the leaves happen to become infected, either from the field or from infectious material in the curing shed. The organism actually producing the decay may also vary with the temperature and humidity as well as with the stage of curing, and consequently we may find a considerable variance in the different sheds and in different years in the same locality."

Although admitting that bacterial decay may occur under extreme conditions of humidity, he concludes that: "The ordinary shed burn, as far as my observations go in Wisconsin, seems to be due entirely to fungi. . In Wisconsin, Fusarium particularly seems to cause the decay known as stem rot and shed burn equally well, and for this reason it appears that the two diseases may be caused by the same organism and that they differ mainly in the point and time of decay".

Recently a more thorough investigation of the disease has been conducted in Wisconsin by Johnson and Ogden?. After several years of investigating the small spots, (presumably of the freckle rot type described above) they conclude: "Practically without exception, only one fungus has been found to predominate in these spots". This fungus was identified as Alternaria tenuis Nees. With regard to the stem rot, they state that

\footnotetext{
Johnson, J. Black rot, shed burn and stem rot of tobacco. Wis. Agr. Exp. Sta. Research Bul. 32: 81-85. 1914.

${ }^{2}$ Johnson, James and W. B. Ogden. The relation of air conditions to tobacco curing. Wis. Agr. Exp. Sta. Res. Bul. 110: 40-45. 1931.
} 
"the evidence seems to indicate that a number of different fungi may be concerned" and the reader is referred to Johnson's previous work quoted above for the names of these species.

A review of all that has been published on the subject shows that there is thus considerable diversity of opinion as to the organisms responsible for pole rot, or that there are different causal organisms depending on the locality in which the investigation was conducted. In view of this rather uncertain state of our knowledge of causal agencies, the writer began an investigation of the organisms associated with rotting tobacco leaves with the hope of determining whether any single one is the initiator of the trouble in Connecticut, and the relationship of the others to the various forms of pole rot. Since it is possible that the organisms concerned in one form of the trouble may not be the same as those associated with another form, it was planned to take up each type of the disease by itsel without generalizing on all its manifestations. In the present disciussion, therefore, there are recorded only those investigations and observations that concern the "freckle rot" type of pole rot, reserving for a later paper the "web rot" and "vein rot" types.

The small, isolated, dark spots characteristic of freckle rot have been described above under "symptoms". Examination of a large number of the smallest (presumably youngest) of these spots in the sheds failed to show spores of fungi on the surface. When the leaves are kept in a moist chamber for a sufficiently long time, fungi of several species develop on the surface. However, to assume that these were the same fungi that produced the spots might easily lead to a false conclusion. V'ery small spots-not larger than a pinhead-taken directly from the shed and showing no surface growth, were cut ont of the leaves, the tissues thoroughly teased apart under a dissecting microscope and examined under high magnification. Examination of hundreds of these spots showed that the tissues were filled with fungous mycelia of only one type. Bacteria in any quantity were not found in these youngest spots. The fungous mycelium is hyaline (dark only when outside the matrix), stout (3.7 microns in diameter) thick-walled, distinctly septate and usually constricted at the septa, much branched, winding and irregular in direction and in size of cells. The cells are usually two or three times as long as they are broad and inclined to be slightly dumb-bell shaped. Frequently, however, there are chains of globular, shorter, subglohose cells of larger diameter (Figure 141), a condition that seems to be distinctive for this species. Another distinctive feature of this mycelium is the manner of branching, which is commonly dichotomous from the enlarged end of a pear-shaped basal cell, although true monopodial, and other irregular types of branching, may also be found. After a little experience, this mycelium could readily be differentiated from all other species of mycelium found on tobacco leaves. It was obviously the only kind of organism that occurred commonly in these spots.

The fungus was next isolated by cutting out tiny pieces from the smallest spots with a flamed scalpel, washing through several changes of sterile water and transferring to potato dextrose agar plates. From about 95 per cent of such transfers, only one fungus grew on the agar. This same fungus was present on the other 5 per cent but was accompanied by other fungi. It quickly sporulated, was transferred, measured and studied and found to be Alternaria tenuis Nees. Since this species was fully described 
and pictured in last year's report, (Bul. 367: 132) in connection with "white speck" on tobacco leaves, no description of its morphological characters is repeated here.

No satisfactory method of inoculating half-cured leaves under aseptic conditions with this fungus has yet been found by the writer and to that extent the conclusions drawn are subject to criticism. Nevertheless, after studying and isolating the organism from hundreds of these spots from many different sheds during the last two seasons, he is convinced that as far as the Connecticut Valley is concerned, the freckle rot type of pole rot is produced by Alternaria alone. This conclusion is in entire agreement with that expressed by Johnson and Ogden for the Wisconsin area. It may also be stated here that Alternaria has been constantly found in comnection with the other types of pole rot, but the presence of several

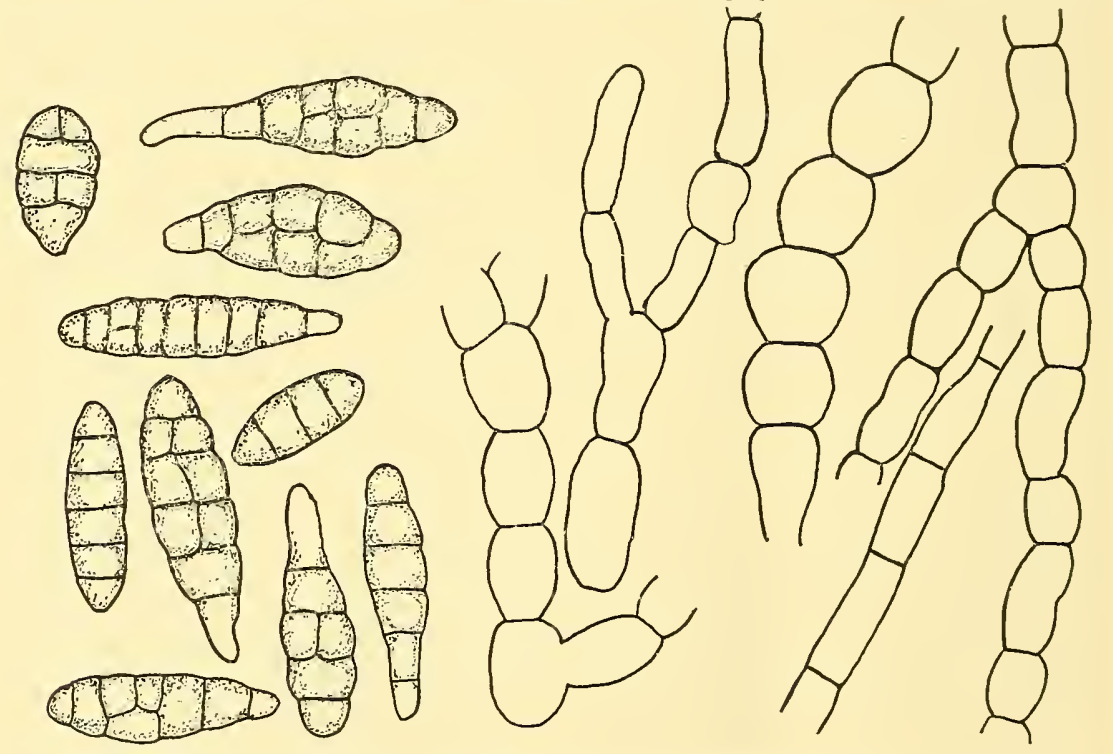

Figure 141. Alternaria tenuis, the causal organism of freckle type of pole rot. Spores (left) magnified 550 diameters. Internal myselium (right) magnified 1000 diameters.

other species of fungi (Botrytis cinera, Cladosporium, Fusaria, etc.) as well as bacteria in many cases, makes it difficult to determine which have a causal relation. There is need here of further investigation to determine the role played by these various species. Certainly one is not warranted in concluding, since freckle rot is produced by only one organism, that web rot and vein rot are also produced by the same fungus.

Since spores of these different species of fungi are probably present in great numbers on the leaves, the question naturally arises: Why is Alternaria the only one that produces the freckle rot type of spot? Previous investigations by the writer on white speck (Bul. 367: 134) and on dead blossom leaf spot (p 596), of Tisdale and Wadkins ${ }^{1}$ on brown spot and of Ghimpur in Europe, indicate that this species of Alternaria, although

\footnotetext{
path. 21:641. 1931.

${ }^{2}$ Ghimpu, V. La maladie des tabac causee par Pleospora Alternariae. Bul. Cult. si ferment. Tutunului 20. (No. 1) : 1-27. 1931.
} 
not a virulent parasite, is nevertheless in the group of fungi known as facultative parasites or semi-parasites. Since, at the critical stage of curing mentioned above, the leaf is still alive but at the same time is getting weaker daily and losing its resistance, we may suppose that the fungus which comes nearest to being a parasite will be the first one to gain entrance to the tissues, and that it may be followed later by others of weaker parasitism until, when the cells are quite dead, the pure saprophytes will cause rot. The most nearly parasitic fungus in this case is Alternaria tenuis, hence it is the one that produces the first stages of rot.

Another question to be answered: How do the spores of Alternaria come to be present in such numbers on curing tobacco leaves? The writer has found this species sporulating on white speck lesions, blossom rot lesions, and angular leaf spot and mosaic rust, in fact almost any injured part of the leaf becomes infected and produces many spores which are carried into the curing shed. Even more important is the great abundance of these spores on the dead sand leaves. Since the species sporulates on many other species of plants and vegetable debris from which the spores may be blown or ortherwise carried to tobacco leaves, it is easy to see how they would be present on the surface of the leaves in great number whenever tobacco is taken into the shed.

\section{EFFECT OF SHADE CLO'TH ON ATMOSPHERIC CONDITIONS}

Observations on the effect of shade cloth on light intensity reported last year (Conn. Agr. Exp. Sta. Bul. 367: 143) were repeated at intervals during the growing season of 1935. In addition, measurements of temperature and relative humidity were made with a sling psychrometer. The instrument and technique employed for light measurements were the same as in 1934. Table 28 summarizes the results.

Reductions of light intensity under shade tents ranged from 30 to 63 per cent, almost identical with last year. Measurements under trees were added to show the relative reduction under heavy shade, and ranged from 83 to 95 per cent of intensities in the open.

Temperature and relative humidity measurements disclose interesting facts. Temperatures were lower under the shade tent in three out of five cases and equal in the other two cases. Relative humidities were from 11 to 23 per cent higher in all but one case, a foggy morning. The common belief that air temperatures are several degrees higher under shade tents is thus an error. The observer gets this impression because of the lower evaporating power of the air, and the consequent higher body temperature.

Relative humidity measurements are of much value in an interpretation of the effect of shading. An average increase of 15 per cent in relative humidity, together with a decrease of 50 per cent in light intensity, is the equivalent of a southern climate many degrees of latitude removed from Connecticut conditions. The effect on the physical characteristics and chemical composition of the plant is very pronounced, as was noted in last year's report. 
Table 28. The Effect of Shading on Light, Temperature and Relative Humidity

\begin{tabular}{|c|c|c|c|c|c|c|c|}
\hline Date & Hour & Weather & Location & $\begin{array}{l}\text { Light in } \\
\text { candles } \\
\text { per sq. } \\
\text { ft. }\end{array}$ & $\begin{array}{l}\text { Dry } \\
\text { bulb }\end{array}$ & $\begin{array}{l}\text { Wet } \\
\text { bulb }\end{array}$ & $\begin{array}{l}\% \\
\text { relative } \\
\text { humidity }\end{array}$ \\
\hline \multirow[t]{3}{*}{ July 19} & \multirow[t]{3}{*}{ 11:30 A.M. } & \multirow[t]{3}{*}{ Calm } & Under tree & 150 & 90 & 77 & 5.5 \\
\hline & & & In open & 900 & 92 & 79 & 56 \\
\hline & & & Under tent & 400 & 91 & 83 & 71 \\
\hline \multirow[t]{3}{*}{ July 23} & \multirow[t]{3}{*}{ 1:15 P.M. } & Light & Under tree & 90 & 89 & 77 & 57 \\
\hline & & breeze & In open & 1000 & 91 & 79 & 58 \\
\hline & & & Under tent & 700 & 90 & 85 & 81 \\
\hline \multirow{2}{*}{ July 26} & \multirow{2}{*}{1 P.M. } & Intermittent & Under tree & 50 & 77 & 64 & 49 \\
\hline & & strong breeze & In open & 1000 & 81 & 67 & 48 \\
\hline \multirow{3}{*}{ Aug. 2} & \multirow{3}{*}{7 A.M. } & & unaer tent & 600 & 01 & 12 & 64 \\
\hline & & Lignt & Un oner & 35 & $\because 7$ & 68 & 20 \\
\hline & & & Under tent & 130 & 75 & 71 & $\begin{array}{r}1 \\
82\end{array}$ \\
\hline \multirow[t]{3}{*}{ Aug. 17} & \multirow[t]{3}{*}{ 9:30 A.M. } & Calm, fog & Under treè & 40 & 75 & 70 & 78 \\
\hline & & dissipating & In open & 700 & 79 & 73 & 75 \\
\hline & & & Under tent & 400 & 79 & 73 & 7.5 \\
\hline
\end{tabular}

\section{$5388 \quad 62$}






\section{University of}

Connecticut

Libraries

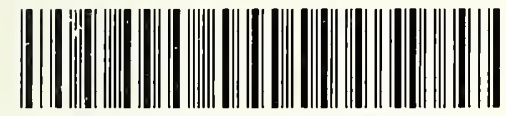

$\overline{3} \overline{9} 15 \overline{3} 0 \overline{2} \mathbf{8} \overline{8} \overline{4} \overline{4} \overline{7} 2$ 


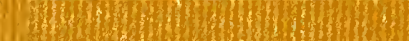

